\title{
Assessing ocean alkalinity for carbon sequestration
}

Phil Renforth, School of Earth and Ocean Sciences, Cardiff University, UK (RenforthP@Cardiff.ac.uk)

Gideon Henderson, Department of Earth Sciences, University of Oxford, Oxford, UK (gideonh@earth.ox.ac.uk)

\section{Key Points}

The ocean naturally stores a very large quantity of carbon as dissolved carbonate and bicarbonate ions

It may be possible to store additional carbon in this sink to mitigate climate change at costs that are comparable to conventional mitigation

Research is needed to understand the impacts and the feasibility of this approach

\begin{abstract}
Over the coming century humanity may need to find reservoirs to store several trillions of tons of carbon dioxide $\left(\mathrm{CO}_{2}\right)$ emitted from fossil fuel combustion, which would otherwise cause dangerous climate change if it were left in the atmosphere. Carbon storage in the ocean as bicarbonate ions (by increasing ocean alkalinity) has received very little attention. Yet, recent work suggests sufficient capacity to sequester copious quantities of $\mathrm{CO}_{2}$. It may be possible to sequester hundreds of billions to trillions of tonnes of $\mathrm{C}$ without surpassing post-industrial average carbonate saturation states in the surface ocean. When globally distributed, the impact of elevated alkalinity is potentially small, and may help ameliorate the effects of ocean acidification. However, the local impact around addition sites may be more acute but is specific to the mineral and technology.
\end{abstract}

The alkalinity of the ocean increases naturally because of rock weathering in which $>1.5$ moles of carbon are removed from the atmosphere for every mole of magnesium or calcium dissolved from silicate minerals (e.g., wollastonite, olivine, anorthite), and 0.5 moles for carbonate minerals (e.g., calcite, dolomite). These processes are responsible for naturally sequestering 0.5 billion of $\mathrm{CO}_{2}$ tons per year. Alkalinity is reduced in the ocean through carbonate mineral precipitation, which is almost exclusively formed from biological activity. Most of the previous work on the biological response to changes in carbonate chemistry have focused on acidifying conditions. More research is required to understand carbonate precipitation at elevated alkalinity to constrain the longevity of carbon storage.

A range of technologies have been proposed to increase ocean alkalinity (accelerated weathering of limestone, enhanced weathering, electrochemical promoted weathering, ocean liming), the cost of which may be comparable to alternative carbon sequestration proposals (e.g., \$20 - $100 \mathrm{tCO}_{2}{ }^{-1}$ ). There are still many unanswered technical, environmental, social, and ethical questions, but the scale of the carbon sequestration challenge warrants research to address these.

\section{Index Terms/Keywords}


AWL Accelerated weathering of limestone

BECCS Biomass energy carbon capture and storage

$\mathrm{CO}_{2} \quad$ Carbon dioxide

C

Carbon. Descriptions of global distribution and fluxes are described in billions of tons (Gt) of $\mathrm{C}$ to account for the various compounds in which $\mathrm{C}$ exists. The equivalent amount of $\mathrm{CO}_{2}$ can be calculated by multiplying by 3.67.

$\mathrm{CaCO}_{3} \quad$ Calcium carbonate (typically as calcite or aragonite polymorphs)

$\mathrm{CaO} \quad$ Lime

$\mathrm{Ca}(\mathrm{OH})_{2} \quad$ Portlandite

CCD Carbonate compensation depth (in the ocean)

CCS Carbon capture and storage

$\mathrm{C}_{\mathrm{T}} \quad$ Dissolved inorganic carbon (also 'DIC')

Gt Gigatons (or Pg)

kJ Kilojoules

Ksp Solubility product constant

$\mu$ atm Microatmospheres (units of pressure)

$\mathrm{NaOH} \quad$ Sodium hydroxide

$\mathrm{pCO}_{2} \quad$ Partial pressure of $\mathrm{CO}_{2}$

PIC Particulate inorganic carbon

POC Particulate organic carbon

ppmv Parts per million by volume

RCP Representative concentration pathway (of greenhouse gases in the atmosphere to produce between 2.6 and $8.5 \mathrm{~W} \mathrm{~m}^{-2}$ of radiative forcing on the global climate system)

$\Omega_{\text {calcite }} \quad$ The saturation state of calcite in solution $\left(\Omega_{\text {aragonite }} \approx 0.66 \Omega_{\text {calcite }}\right)$

[X] Square brackets denote concentrations of aqueous element or compound X

\section{Introduction}

\subsection{Context and Scope}

Stabilizing and reducing atmospheric carbon dioxide $\left(\mathrm{CO}_{2}\right)$ concentrations to avoid 'dangerous' climate change is one the greatest challenges facing humanity in the $21^{\text {st }}$ Century. Long-term sustainable solutions include the reduction of $\mathrm{CO}_{2}$ emissions by decarbonizing energy generation, demand reduction through efficiency improvements, and responsible land use management [Edenhofer et al., 2014]. However, these require a tremendous change in our technological and socio-economic systems that may take decades or even centuries to 
implement. The Paris Agreement [UNFCCC 2015], which entered into force in November 2016, aims to hold global temperature changes below $2{ }^{\circ} \mathrm{C}$ through nationally declared contributions to greenhouse gas emission reductions. While 136 countries have ratified the agreement, the pledged contributions are insufficient to prevent a $2^{\circ} \mathrm{C}$ temperature rise [Rogelj et al. 2016].

Many future scenarios that keep climate change below $2^{\circ} \mathrm{C}$ do so not only by limiting the use of carbon, but by using technology to limit the impact of carbon use on the atmospheric concentration. These technologies allow the use of fossil fuels but either prevent $\mathrm{CO}_{2}$ emission into the atmosphere (e.g., carbon capture and storage,[Metz et al., 2005]) or remove $\mathrm{CO}_{2}$ from the atmosphere once there ('negative emissions', [Fuss et al., 2014; McLaren 2012]).

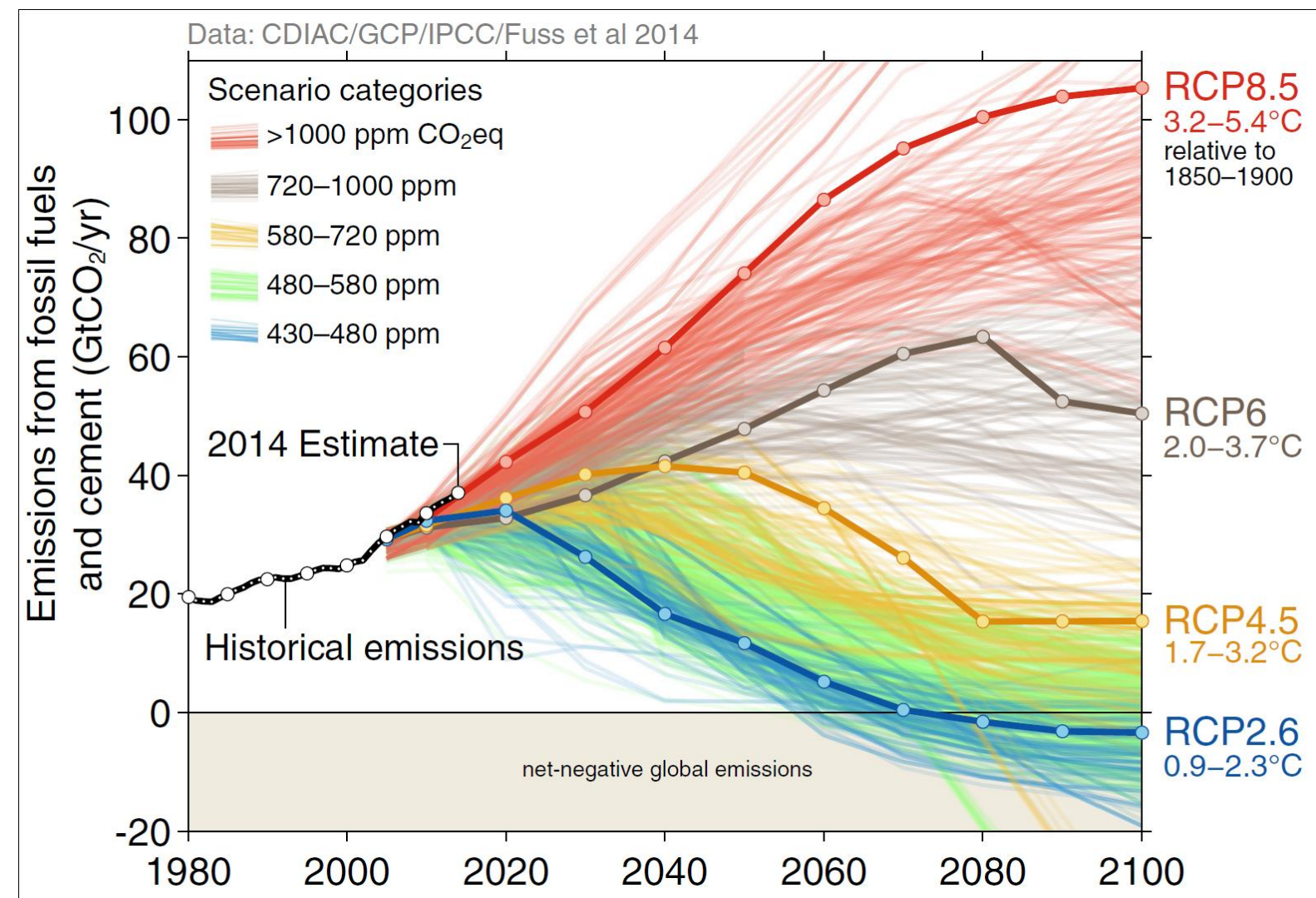

Figure 1: Emission scenarios for representative concentration. Reprinted by permission from Macmillan Publishers Ltd: Nature Climate Change [Fuss et al., 2014], copyright @ 2014.

The representative concentration pathway (RCP) that results in a likely temperature rise by 2100 below $2^{\circ} \mathrm{C}$ is RCP2.6 (Figure 1, see [van Vuuren et al., 2011]), which suggests a cumulative emission of $880 \mathrm{Gt} \mathrm{C}$ (we use Gt C in this study, but these values can be converted to $\mathrm{Gt} \mathrm{CO}_{2}$ by multiplying by 3.66) This RCP explicitly includes $40-220 \mathrm{Gt} \mathrm{C}$ of negative emissions [Edenhofer, 2014]. Scenarios where more carbon is burned either result in warming in excess of $2^{\circ} \mathrm{C}$, or require even more significant removal of $\mathrm{CO}_{2}$ at source or from the atmosphere. With current conventional fossil fuel reserves $~ 3,000 \mathrm{Gt} \mathrm{C}$ [McGlade and Ekins 2015], carbon storage requirements could extend to thousands of Gt. There are few sinks with the capacity to store hundreds of $\mathrm{Gt} \mathrm{C}$, with that most often considered being $\mathrm{CO}_{2}$ injection underground in depleted hydrocarbon reservoirs or saline aquifers. Estimates of carbon storage in this reservoir are on the order of 100-1,000 Gt C [Bradshaw et al., 2007] Other options include biomass growth ( 100 Gt C) [Nilsson and Schopfhauser, 1995], mineralization of 
natural ( $10^{5}$ Gt C) [Sanna et al., 2014] and waste ( 50-100 Gt C) [Renforth et al., 2011] materials, enhanced ocean productivity (26-180 Gt C) [Denman 2008], and the subject of this review: inorganic storage in the ocean.

The oceans contain $\approx 38,000 \mathrm{Gt} \mathrm{C}$, some 45 times more than the present atmosphere, and oceanic uptake has already consumed close to $40 \%$ of anthropogenic $\mathrm{C}$ emissions [Sabine and Tanhua, 2010]. On long-timescales ( 100-200 ka) the ocean and weathering will reduce atmospheric $\mathrm{CO}_{2}$ to values close to pre-industrial [Lord et al., 2016]. So the issue is not capacity, but rather a question of how to accelerate oceanic uptake and storage in a safe and cost effective way. Given the increasing reliance of future climate scenarios on negative emission, and the size of $\mathrm{C}$ sequestration that may be required, it is important to explore and understand the feasibility of all possible $\mathrm{C}$ sinks, including acceleration of the natural oceanic sink.

Sequestration of inorganic $\mathrm{C}$ in the ocean is the least represented climate mitigation strategies in the literature [Bellamy et al., 2012]. This has led to considerable uncertainty about the potential storage capacity, environmental impact, and cost of this approach [NAS 2015]. The aim of this paper is to review all aspects of the inorganic $\mathrm{C}$ sink in the ocean, including the function of alkalinity in the natural oceanic $\mathrm{C}$ cycle (section 2), the changes in ocean chemistry imposed by artificial alkalinity changes (section 3), the stability of increased alkalinity in the ocean (section 4), technologies for increasing ocean alkalinity (section 5 and 6), and the potential environmental impact (section 6 and 7). This builds on existing general discussions of geochemical $\mathrm{C}$ sequestration, which ocean carbon storage is introduced in the context of other removal schemes [Lackner 2002; Stephens and Keith 2008]. Alkalinity storage in the ocean raises issues around environmental impact, quantification, monitoring, governance, and longevity, all of which will be explored in detail in this review.

Storage of $\mathrm{C}$ by increasing ocean alkalinity requires the extraction, processing, and dissolution of minerals. This results in chemical transformation of $\mathrm{CO}_{2}$ and sequestration as bicarbonate and carbonate ions $\left(\mathrm{HCO}_{3}{ }^{-}, \mathrm{CO}_{3}{ }^{2-}\right)$ in the ocean. Dissolution of a mole of $\mathrm{Ca}^{2+}$ or $\mathrm{Mg}^{2+}$ sequesters close to 2 moles of $\mathrm{C}$ (see section 2). So even dissolution of carbonate minerals (e.g., $\mathrm{CaCO}_{3}$ ) which contain a mole of $\mathrm{C}$ leads to some drawdown of $\mathrm{CO}_{2}$. Table 1 presents some reaction pathways for naturally occurring and anthropogenically produced minerals. A list of acronyms is included in the appendix.

Table 1. Carbon sequestration reactions for a range of naturally occurring and anthropogenically produced minerals.

\begin{tabular}{|c|c|c|c|c|c|c|}
\hline $\begin{array}{l}\text { Equation } \\
\text { Number }\end{array}$ & Mineral & $\begin{array}{c}\Delta \mathbf{G}_{\mathbf{f}} \\
(\mathbf{k} \mathbf{J} / \\
\mathbf{m o l e})^{\mathbf{a}}\end{array}$ & Reaction & $\begin{array}{c}\Delta \mathbf{G}_{\mathbf{r}} \\
(\mathbf{k J} / \\
\text { mole })^{\mathrm{a}}\end{array}$ & $\begin{array}{c}\Delta \mathbf{G}_{\mathbf{r}} \\
(\mathrm{kJ} / \\
\text { mole } \\
\mathrm{C})^{\mathrm{a}} \\
\end{array}$ & $\begin{array}{c}\mathrm{gCO}_{2} / \\
\mathrm{g}(\mathrm{min} \\
\text { eral })\end{array}$ \\
\hline \multicolumn{7}{|c|}{ Naturally occurring minerals } \\
\hline 1 & $\begin{array}{l}\text { Magnesit } \\
\mathrm{e}\end{array}$ & -1029.5 & $\begin{array}{c}\mathrm{MgCO}_{3}+\mathrm{CO}_{2}+\mathrm{H}_{2} \mathrm{O} \rightarrow \mathrm{Mg}^{2+} \\
+2 \mathrm{HCO}_{3}^{-}\end{array}$ & 22.5 & 22.5 & 0.52 \\
\hline 2 & Calcite & -1128.5 & $\begin{aligned} \mathrm{CaCO}_{3}+\mathrm{CO}_{2} & +\mathrm{H}_{2} \mathrm{O} \rightarrow \mathrm{Ca}^{2+} \\
& +2 \mathrm{HCO}_{3}^{-}\end{aligned}$ & 22.8 & 22.8 & 0.44 \\
\hline
\end{tabular}




$$
\begin{aligned}
& \rightarrow \mathrm{Ca}^{2+}+\mathrm{Mg}^{2+} \\
& +4 \mathrm{HCO}_{3}^{-}
\end{aligned}
$$

4

Forsterite $-2053.6 \mathrm{Mg}_{2} \mathrm{SiO}_{4}+4 \mathrm{CO}_{2}+4 \mathrm{H}_{2} \mathrm{O}$

$$
\rightarrow 2 \mathrm{Mg}^{2+}
$$

$+4 \mathrm{HCO}_{3}^{-}$

$+\mathrm{H}_{4} \mathrm{SiO}_{4}$

5

$$
\text { Anorthite -4007.9 } \begin{aligned}
\mathrm{CaAl}_{2} \mathrm{Si}_{2} \mathrm{O}_{8}+ & 2 \mathrm{CO}_{2}+3 \mathrm{H}_{2} \mathrm{O} \\
& \rightarrow \mathrm{Ca}^{2+}+2 \mathrm{HCO}_{3}^{-} \\
& +\mathrm{Al}_{2} \mathrm{Si}_{2} \mathrm{O}_{5}(\mathrm{OH})_{4}
\end{aligned}
$$

Anthropogenically produced minerals

6

Lime
Portlandi
$-603.5$

$$
\mathrm{CaO}+2 \mathrm{CO}_{2}+\mathrm{H}_{2} \mathrm{O} \rightarrow \mathrm{Ca}^{2+}
$$

$$
+2 \mathrm{HCO}_{3}^{-}
$$

te

$$
-898.4
$$

$\mathrm{Ca}(\mathrm{OH})_{2}+2 \mathrm{CO}_{2}+\mathrm{H}_{2} \mathrm{O}$

$\rightarrow \mathrm{Ca}^{2+}+2 \mathrm{HCO}_{3}^{-}$

8

Periclase

$-569.2$

$\mathrm{MgO}+2 \mathrm{CO}_{2}+\mathrm{H}_{2} \mathrm{O} \rightarrow \mathrm{Mg}^{2+}$

$$
+2 \mathrm{HCO}_{3}^{-}
$$

9

Brucite

$$
-833.5
$$

$\mathrm{Mg}(\mathrm{OH})_{2}+2 \mathrm{CO}_{2}+\mathrm{H}_{2} \mathrm{O}$

$\rightarrow \mathrm{Mg}^{2+}$

$$
+2 \mathrm{HCO}_{3}^{-}
$$

Electrochemical Weathering

$$
\begin{aligned}
\mathrm{NaCl}(a q)+ & \mathrm{H}_{2} \mathrm{O}(l) \\
& \rightarrow \mathrm{NaOH}(a q) \\
& +0.5 \mathrm{Cl}_{2}(g) \\
& +0.5 \mathrm{H}_{2}(g)
\end{aligned}
$$

$$
(g) \rightarrow H C l(a q)
$$$$
4 \mathrm{HCl}(a q)+\mathrm{Mg}_{2} \mathrm{SiO}_{4}(s)
$$$$
\rightarrow 2 \mathrm{MgCl}_{2}(\mathrm{~s})
$$$$
+\mathrm{SiO}_{2}(s)
$$$$
+\mathrm{H}_{2} \mathrm{O}(l)
$$

${ }^{\mathrm{a}}$ Thermodynamic information was sourced from [Robie and Hemingway 1979]

\subsection{History of research investigating ocean alkalinity as an engineered carbon sink}

The use of enhanced ocean alkalinity for C storage was first proposed by Kheshgi [1995]. Realizing the slow rate of natural mineral dissolution, Kheshgi [1995] proposed the creation of highly reactive lime $(\mathrm{CaO})$ or portlandite $\left(\mathrm{Ca}(\mathrm{OH})_{2}\right)$ from the calcination of limestone. Notionally, $\mathrm{CaO}$ or $\mathrm{Ca}(\mathrm{OH})_{2}$ would readily dissolve in the surface ocean and sequester $\mathrm{CO}_{2}$ through the reactions in Table 1 . The high energy costs of creating lime, and research focus on other forms of climate change mitigation, has meant that the proposal was largely disregarded in the 1990's and early 2000's. Interest in ocean liming (and more generally ocean alkalinity for carbon storage) was reinvigorated around debates about geoengineering [e.g., The Royal Society, 2009]. In this context, the techno-economic feasibility of Ocean Liming was re- 
examined by Renforth et al., [2013], who suggest similar energy and financial requirements to other air capture technologies. However, both Kheshgi [1995] and Renforth et al., [2013] recognized that the production of lime from limestone may not be the most efficient process for increasing ocean alkalinity due to the large energy and $\mathrm{CO}_{2}$ burden of calcination. The development of this idea and the proposed integration of mineral carbonation [Renforth and Kruger 2013] is expanded upon here in section 5. Consideration of ocean alkalinity carbon storage has largely been driven by technology proposals. An unpublished white paper [Henderson et al., 2008] discussed the broad range of biogeochemical consequences of ocean liming, and highlighted knowledge gaps including poor constraints of the relationship between elevated carbonate mineral saturation and precipitation, uncertainty in the impact of elevated alkalinity on biology, and the rate of dispersion/dilution of added materials.

An alternative proposal was developed independently by Rau and Caldeira [1999], who suggested that the dissolution of carbonate minerals (e.g., $\mathrm{CaCO}_{3}$ ) exposed to waste flue gas $\mathrm{CO}_{2}$ and seawater (Accelerated Weathering of Limestone; AWL) as a means for increasing ocean alkalinity. The ultimate fate of the stored carbon is the same as ocean liming (i.e. $\mathrm{HCO}_{3}{ }^{-}$ and $\mathrm{CO}_{3}{ }^{2-}$ ions), but the reaction pathway is different. Raising the partial pressure of $\mathrm{CO}_{2}$ to $>5,000 \mu \mathrm{atm}$ (at a total pressure of $1 \mathrm{~atm}$ ) in contact with seawater, creates the conditions in which carbonate minerals can spontaneously dissolve. Therefore, contacting carbonate minerals, seawater and power station flue gas $\left(10 \% \mathrm{CO}_{2}\right.$ at $\left.1 \mathrm{~atm}\right)$, would result in increased alkalinity in the effluent discharged back to the ocean. The key limitation of this process is the amount of water required, in which thousands of tons of seawater are needed per ton of $\mathrm{CO}_{2}$ sequestered. However, Rau and Caldeira [1999] point out that the once-through cooling water consumed within some power stations equates to around 400 tons per ton of $\mathrm{CO}_{2}$ emitted, thus lowering the additional water requirements of AWL. Caldeira and Rau [2000] suggested the cost and environmental impact compares favorably to direct injection of $\mathrm{CO}_{2}$ in the deep ocean. The engineering requirements were developed in Rau et al., [2007], and Langer et al., [2009] who explored the processing and handling costs of an up-scaled industry (discussed further in section 5). Rau (2011) provided results from the operation of a bench-scale experiment, which demonstrated high levels of $\mathrm{CO}_{2}$ sequestration largely as a function of the solution/gas volume ratio within the reactor. He showed that a solution:gas flow ratio of 8 was sufficient to capture $85 \%$ of the $\mathrm{CO}_{2}$ from a $10 \%$ gas at 1 atm. Chou et al., [2015] investigated the operation of a two stage AWL reactor in which gas-liquid equilibration occurs prior to solid-liquid equilibration, and found lower carbon sequestration efficiencies of $<50 \%$. Despite this work, AWL research has been largely confined to small-scale experiments.

The dissolution of minerals in a carbonic acid solution is relatively slow compared to stronger acids. Therefore, House et al., [2007] proposed the creation of alkalinity in the ocean through electrolysis (equation 10 in Table 1) and the reaction of the $\mathrm{Cl}_{2}$ and $\mathrm{H}_{2}$ gaseous products in a fuel cell to produce electricity and hydrochloric acid (equation 11). The acidity is then neutralized through the dissolution of a silicate mineral (equation 12). While the kinetics of this process would be rapid, the energy requirements are substantial (section 5). An alternative electrochemical approach was proposed in which $\mathrm{CaCO}_{3}$ [Rau 2008] or a magnesium silicate [Rau et al., 2013] was dissolved around an acidic anode and a high $\mathrm{pH}\left(\mathrm{Ca}(\mathrm{OH})_{2}\right.$ or $\left.\mathrm{Mg}(\mathrm{OH})_{2}\right)$ solution was created around the cathode. The high $\mathrm{pH}$ solution would then be used to remove $\mathrm{CO}_{2}$ from air directly, with the resulting bicarbonate-rich solution added to the ocean. 
Alternatively, the hydroxide could be added to the ocean to consume excess $\mathrm{CO}_{2}$. In either case ocean alkalinity is increased.

A number of studies investigate the potential of adding naturally occurring minerals directly to the land surface [Hartmann et al., 2013; Hartmann and Kempe 2008; Köhler et al., 2010; Manning 2008; Manning et al., 2013; Moosdorf et al., 2014; Renforth 2012; Schuiling and Krijgsman 2006; Taylor et al., 2016; ten Berge et al., 2012), coastal environments (Hangx and Spiers 2009; Schuiling and de Boer 2010; Montserrat et al., 2017; Meysman and Montserrat 2017], and the open ocean [Harvey 2008; Köhler et al., 2013]. The feasibility of such approaches is still highly contested given the slower dissolution kinetics at ambient temperatures and pressures, and the solubility limits of naturally occurring minerals. However, the direct comparison to elevated temperature/pressure mineral carbonation is problematic, as constraints of reactor size are removed. In chemical engineering, a reaction time on the order of minutes is required to facilitate reasonable reactor sizes for commercial operations. Reactions in the open environment could have a time constraint on the order of years $\left(10^{5}-10^{6}\right.$ times longer) because of the much larger volume. On one hand, spreading natural minerals on the land surface [reviewed by Hartmann et al., 2013] potentially allows the naturally corrosive chemistry in soil pore waters [Manning and Renforth 2013] to be used to accelerate dissolution kinetics. Notionally, the products of dissolution (including increased alkalinity of rainwater) are transported to the ocean via runoff, rivers and shallow groundwater. Alternatively, Manning [2008] and Manning et al., [2013] suggest that solution chemistry in soil pore-waters may promote the precipitation of carbonate minerals, which has been demonstrated widely in anthropogenic soils [Renforth et al., 2009; Washbourne et al., 2015, 2012]. If so, the precipitated carbonate becomes the sink for $\mathrm{CO}_{2}$ rather than ocean alkalinity. If ocean $\mathrm{HCO}_{3}{ }^{-}$ and $\mathrm{CO}_{3}{ }^{2-}$ were the sole repository of the carbon, then others argue that such an approach may be limited by the saturation state or environmental $\mathrm{pH}$ limits of the rain/river water [Köhler et al., 2011]. It may be possible to use the constantly refreshed water of coastal environments, in which wave action could increase the attrition of mineral particles [Schuiling and de Boer 2010; Montserrat et al., 2017; Meysman and Montserrat 2017]. However, the slightly alkaline pH of ocean water is likely to retard dissolution kinetics so that very small particles are needed [Hangx and Spiers 2009]. For instance, Köhler et al., [2013] investigated the direct addition of olivine particles to the surface ocean. As it is imperative that the added particles dissolve within the mixed layer, they suggest that crushing and grinding to a diameter of $1 \mu \mathrm{m}$ is necessary.

It is highly unlikely that any of the above proposals (e.g., Figure 2) will form humanity's sole response to climate change. However, at this stage, there is nothing that warrants their exclusion from research and policy development, particularly considering that mineral weathering and ocean alkalinity production is the primary mechanism whereby nature will eventually consume and store anthropogenic $\mathrm{CO}_{2}$. 


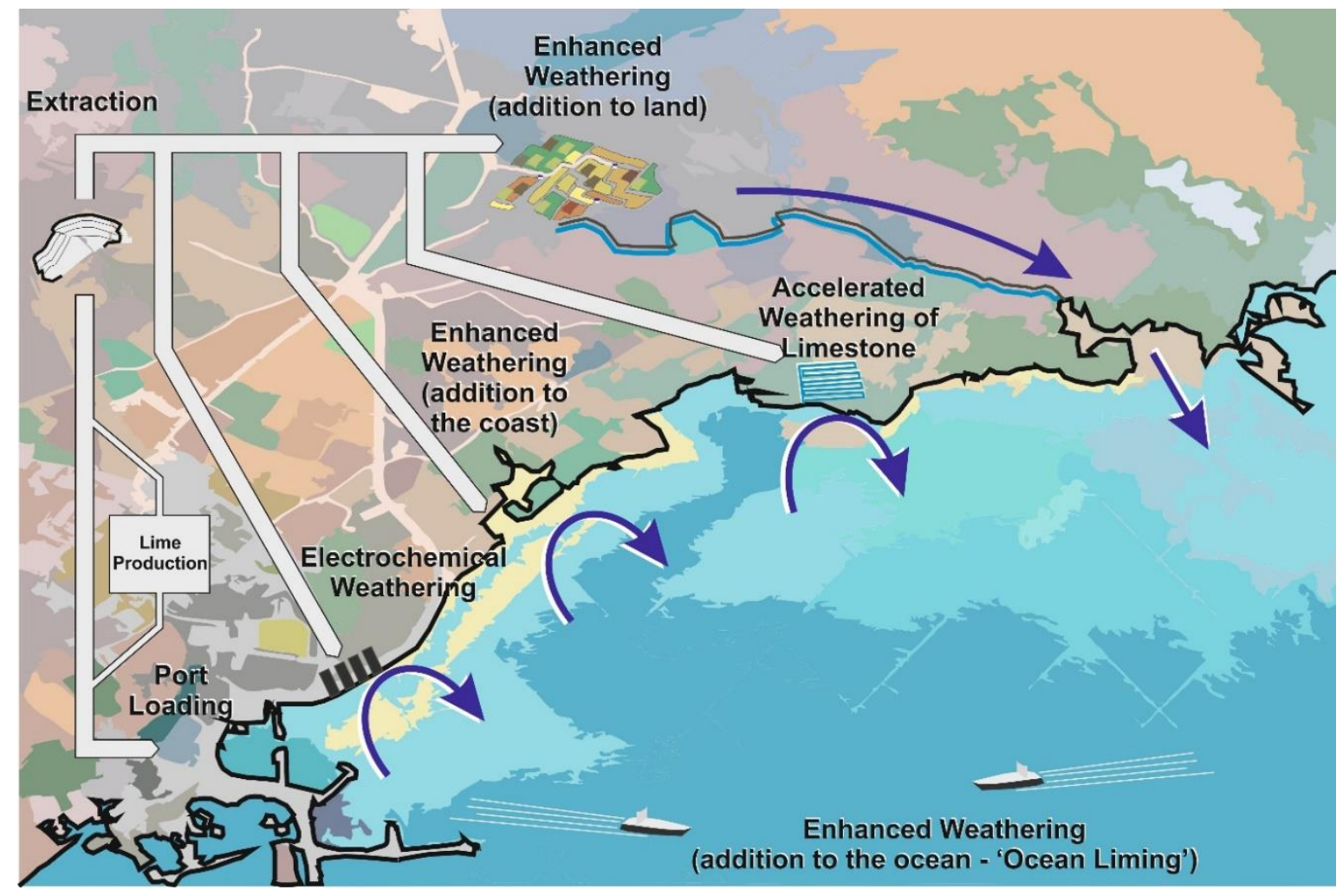

Figure 2: Proposed technologies for carbon storage as ocean alkalinity.

\section{Ocean Carbon Cycle}

Several inter-related processes are responsible for inorganic removal of $\mathrm{CO}_{2}$ from the atmosphere: weathering of silicate and carbonate rocks, reaction with carbonate sediments, and the alkalinity, or buffering capacity, of the ocean. This section provides a brief overview of these processes and their operation in the natural Earth system. It is important to note that these processes are distinct from "the biological pump" in which organic material is produced and settles to the deep ocean (equating to a carbon flux of $\sim 10 \mathrm{Gt} \mathrm{C}^{-1}$ ). That process also plays a critical role in the $\mathrm{C}$ cycle and is the focus of $\mathrm{C}$-sequestration schemes involving ocean fertilization [e.g., Wallace et al., 2010; Williamson et al., 2012]. Overview of the full carbon cycle has also been provided elsewhere, including recently by the IPCC [Ciais et al., 2014], and is not repeated here.

\subsection{Weathering of silicate minerals}

Many silicate minerals were formed at high temperature and are unstable in the presence of water at the temperature and pressure conditions of the surface Earth. These minerals break down slowly at the surface in a variety of reactions together referred to as chemical weathering. At its simplest, these reactions can be characterized by the weathering of wollastonite $\left(\mathrm{CaSiO}_{3}\right.$, equation 13).
$\mathrm{CaSiO}_{3}+\mathrm{CO}_{2} \leftrightarrow \mathrm{CaCO}_{3}+\mathrm{SiO}_{2}$
equation 13 
Other silicate minerals involve a full array of elements and produce a range of other endproducts, frequently including clay minerals, but, as above, are often characterized by the consumption of $\mathrm{CO}_{2}$ (see Table 1 for examples).

These weathering reactions are exothermic, but do proceed slowly due to the significant kinetic limitation created by the strong bonding found in silicate minerals. Because of their importance in global geochemical cycles, controls on the rates at which these reactions proceed have been extensively studied for individual minerals and in natural soils and catchments [White and Brantley 1995]. The principle factors controlling weathering rate are the temperature, run-off (to provide water to remove reaction products), and the available surface area (i.e. the grainsize of the rock or mineral [West et al., 2005]). Biological activity also accelerates weathering [e.g., Cockell 2011]

The total removal of $\mathrm{CO}_{2}$ from the atmosphere by natural weathering of silicate minerals may be as high as $\approx 0.25 \mathrm{Gt} \mathrm{C} \mathrm{a}^{-1}$ [Suchet and Probst 1995; Gaillardet et al., 1999; Hartmann et al., 2009] but is poorly constrained due to difficulty in separating fluxes from weathering silicates and carbonates, and may be significantly smaller [Liu et al., 2011]. On geological timescales, this removal flux is balanced by volcanic sources of $\mathrm{CO}_{2}$ from the Earth interior. These weathering and volcanic fluxes are very small compared to a total mass of carbon in the oceanatmosphere-biosphere system of $\approx 42,000 \mathrm{Gt} \mathrm{C} \mathrm{[Ciais} \mathrm{et} \mathrm{al.,} \mathrm{2014],} \mathrm{so} \mathrm{that} \mathrm{imbalances} \mathrm{between}$ weathering and volcanism must be sustained over long periods (i.e. 100-1,000 ka) to cause significant direct change to the surface-Earth carbon system and climate. Nevertheless, such changes in the weathering/volcanism balance are fundamental in controlling the climate system, and the temperature dependence of weathering rate provides a long-term negative feedback on climate change to keep Earth's long-term climate in a relatively narrow range [Berner et al., 1983].

\subsection{Alkalinity control of ocean C content}

Carbon dioxide reacts with water to form the weak acid, carbonic acid (equation 14).

$\mathrm{CO}_{2}+\mathrm{H}_{2} \mathrm{O} \leftrightarrow \mathrm{H}_{2} \mathrm{CO}_{3} \quad$ equation 14

This acid dissociates to form bicarbonate ion $\left(\mathrm{HCO}_{3}{ }^{-}\right)$and carbonate ion $\left(\mathrm{CO}_{3}{ }^{2-}\right)$, with the extent of dissociation controlled by the excess base in the water. Alkalinity is, by definition, a measure of this excess base (i.e. the capacity of a solution to neutralize acid). As alkalinity increases, more dissociation of carbonic acid occurs, and greater amounts of $\mathrm{C}$ are held in solution as $\mathrm{HCO}_{3}{ }^{-}$and $\mathrm{CO}_{3}{ }^{2-}$ (see Box 1 for details). Seawater has a high alkalinity $(2.5 \mathrm{mEq}$ $\mathrm{kg}^{-1}$ ) which, coupled to the large volume of the ocean, make oceanic inorganic $\mathrm{C}$ by far the largest $\mathrm{C}$ reservoir in the ocean-atmosphere-biosphere system $(\approx 42,000 \mathrm{Gt} \mathrm{C}$; [Ciais et al., 2014]).

The functional value of alkalinity as a chemical property is that it remains unchanged with pressure or temperature, its change describes the cumulative effect of numerous chemical equilibria, and it is a measurable parameter that is useful in reconstructing those systems. There are many definitions of alkalinity, with an entire chapter in the definitive text book, Zeebe and Wolf-Gladrow [2001] devoted to this subject. In the context of this review, however, we use the definition provided by Dickson [1981] in which 'total alkalinity' $\left(\mathrm{A}_{\mathrm{T}}\right)$ is the proton deficiency of a solution relative to an arbitrarily defined zero point (with additional useful 
definitions provided in text of the supporting information [Drever, 1988]). The zero point being the pK value of 4.5 at $25^{\circ} \mathrm{C}$ and zero ionic strength, such that acids with $\mathrm{K}<10^{-4.5}$ (e.g., carbonic acid, boric acid) are proton acceptors and acids with $\mathrm{K}>10^{-4.5}$ (e.g., hydrofluoric acid, hydrochloric acid) are proton donors. (equation 15).

$A_{T}=\left[\mathrm{HCO}_{3}^{-}\right]+2\left[\mathrm{CO}_{3}^{2-}\right]+\left[\mathrm{B}(\mathrm{OH})_{4}^{-}\right]+\left[\mathrm{OH}^{-}\right]+\left[\mathrm{HPO}_{4}^{-}\right]+2\left[\mathrm{PO}_{4}^{2-}\right]+\left[\mathrm{H}_{3} \mathrm{SiO}_{4}^{-}\right]+\left[\mathrm{HS}^{-}\right]+$ $2\left[\mathrm{~S}^{2-}\right]+\left[\mathrm{NH}_{3}^{-}\right]-\left[\mathrm{H}^{+}\right]-\left[\mathrm{HSO}_{4}^{-}\right]-[\mathrm{HF}]-\left[\mathrm{H}_{3} \mathrm{PO}_{4}\right] \quad$ (equation 15)

\section{Box 1: The carbonate system}

A partial pressure difference of $\mathrm{CO}_{2}$ over water will promote transfer across the liquid-gas interface and the dissolution of $\mathrm{CO}_{2}$ into the liquid. Some of that $\mathrm{CO}_{2}$ will hydrate to form carbonic acid $\left(\mathrm{H}_{2} \mathrm{CO}_{3}\right)$. As aqueous $\mathrm{CO}_{2}$ is far more concentrated, it is convenient to

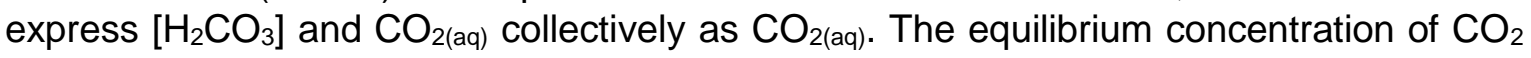
in the water is governed by Henry's law (equation 16):

$$
\left[\mathrm{CO}_{2}(\mathrm{aq})\right]=\mathrm{K}_{\mathrm{CO}_{2}} \cdot \mathrm{fCO}_{2} \quad \text { equation } 16
$$

Where $\mathrm{fCO}_{2}$ is the fugacity of $\mathrm{CO}_{2}\left(\mathrm{fCO}_{2}=\mathrm{pCO}_{2}\right.$ for practical purposes), and $\mathrm{K}_{\mathrm{CO} 2}$ is the Henry's constant. The hydrated aqueous $\mathrm{CO}_{2}$ will deprotonate into bicarbonate $\left(\mathrm{HCO}_{3}{ }^{-}\right)$ and carbonate ions $\left(\mathrm{CO}_{3}{ }^{2-}\right)$ (equations 17 and 18). The relative quantities of which are given by the equilibrium constants $\mathrm{K}_{1}$ and $\mathrm{K}_{2}$ (equations 19 and 20).

$$
\begin{aligned}
& \mathrm{CO}_{2(a q)}+\mathrm{H}_{2} \mathrm{O} \stackrel{\leftrightarrow}{\leftrightarrow} \mathrm{HCO}_{3}^{-}+\mathrm{H}^{+} \quad \text { equation } 17 \\
& \mathrm{HCO}_{3}^{-} \leftrightarrow \mathrm{CO}_{3}^{2-}+\mathrm{H}^{+} \quad \text { equation } 18 \\
& K_{1}=\frac{\left[\mathrm{HCO}_{3}^{-}\right]\left[\mathrm{H}^{+}\right]}{\left[\mathrm{CO}_{2}(\mathrm{aq})\right]} \quad \text { Equation } 19 \quad K_{2}=\frac{\left[\mathrm{CO}_{3}^{2-}\right]\left[\mathrm{H}^{+}\right]}{\left[\mathrm{HCO}_{3}^{-}\right]} \quad \text { equation } 20
\end{aligned}
$$

$\mathrm{H}^{+}$is removed from solution during weathering (equation 1), which results in the forward reactions in equations 17 and 18 . Aqueous $\mathrm{CO}_{2}$ is reduced, and $\mathrm{HCO}_{3}{ }^{-}$and $\mathrm{H}^{+}$produced, to compensate. Simultaneously, some $\mathrm{HCO}_{3}{ }^{-}$will be converted to $\mathrm{CO}_{3}{ }^{2-}$ (equation 18). $\mathrm{CO}_{2}$ will be transferred from the gas phase into the solution to maintain equilibrium in equation 14).

It is possible to constrain and calculate (at known temperature and salinity) the concentrations of $\left[\mathrm{CO}_{2(\mathrm{aq})}\right]\left[\mathrm{HCO}_{3}^{-}\right],\left[\mathrm{CO}_{3}{ }^{2-}\right], \mathrm{pH}, \mathrm{DIC}$, Alkalinity, by only knowing two of the parameters. Details for these calculations are provided in Zeebe and Wolf-Gladrow [2001].

The saturation state of a solution with respect to a mineral is defined in equation 21 (for calcium carbonate). $\Omega=1$ suggests a solution in thermodynamic equilibrium with the mineral phase, whereas, $\Omega<1$ or $>1$ suggests undersaturation and oversaturation respectively.

$$
\Omega=\frac{\gamma_{\mathrm{Ca}_{\mathrm{CO}}}\left[\mathrm{Ca}^{2+}\right]\left[\mathrm{CO}_{3}^{2-}\right]}{K_{S p}} \quad \text { equation } 21
$$

Where $\mathrm{Yca}_{\mathrm{ca}}$ and $\mathrm{Y}_{\mathrm{co}}$ represent the activity coefficients of calcium and carbonate ions respectively, which are difficult to constrain in ionic solutes like seawater [see Mucci 1983] 


\subsection{The combined impact of weathering and ocean alkalinity}

Weathering of silicates on land can remove $\mathrm{CO}_{2}$ from the atmosphere without involving the ocean if the cations releases are all re-precipitated as secondary minerals (e.g., $\mathrm{CaCO}_{3}$ ) on land For example, the reaction between olivine and $\mathrm{CO}_{2}$ to produce magnesium carbonate, equation 22).

$$
\mathrm{Mg}_{2} \mathrm{SiO}_{4}+2 \mathrm{CO}_{2}+2 \mathrm{H}_{2} \mathrm{O} \rightarrow 2 \mathrm{MgCO}_{3}+\mathrm{H}_{4} \mathrm{SiO}_{4} \quad \text { equation } 22
$$

If, on the other hand, the cations are transported to the ocean they increase the alkalinity, and lead to transfer of $\mathrm{CO}_{2}$ to $\mathrm{HCO}_{3}{ }^{-}$and $\mathrm{CO}_{3}{ }^{2-}$. The resulting decrease of dissolved $\mathrm{CO}_{2}$ causes uptake of atmospheric $\mathrm{CO}_{2}$ by air-sea gas exchange.

At the $\mathrm{pH}$ of seawater, most of $\mathrm{C}(\approx 80-90 \%)$ is in the singly-charged $\mathrm{HCO}_{3}{ }^{-}$form (see Box 1$)$. Addition of ions with a divalent charge, such as $\mathrm{Ca}^{2+}$, is therefore compensated by formation of two singly-charged ions containing $\mathrm{C}$, and consequently to uptake of two $\mathrm{CO}_{2}$ molecules from the atmosphere. In practice the uptake is 1.4 to 1.7 molecules because of the presence of some $\mathrm{CO}_{3}{ }^{2-}$, (i.e. a reduction of uptake efficiency, $\eta$, by $15 \%$ - 30\%), depending on temperature, salinity and $\mathrm{pCO}_{2}$ (equation 23; see supporting information for derivation [Dickson, 1990]). The products of silicate weathering (e.g., equation 2) therefore have potential to make a larger impact on $\mathrm{CO}_{2}$ removal if they reach the ocean than if they re-precipitate as secondary minerals.

$$
\begin{aligned}
& \frac{\Delta C_{T}}{\Delta A_{T}}=\eta=\left(S \cdot 10^{-3.009}+10^{-1.519}\right) \ln \left(p C O_{2}\right)-\left(S \cdot 10^{-2.100}\right)-\left(T \cdot p C O_{2}\right)\left(S \cdot 10^{-7.501}-\right. \\
& \left.10^{-5.598}\right)-\left(T \cdot 10^{-2.337}\right)+10^{-0.102} \quad \text { equation } 23 .
\end{aligned}
$$

Where $\mathrm{pCO}_{2}$ is the partial pressure of $\mathrm{CO}_{2}$ in equilibrium with the solution (in $\mu$ atm), and $\mathrm{T}$ is the temperature (in ${ }^{\circ} \mathrm{C}$ ), and $\mathrm{S}$ is the salinity (in \%). This relationship was derived from $\mathrm{CO} 2$ sys [Lewis et al., 1998] using seawater scale $\mathrm{pH}$ and equilibrium constants from Roy et al., [1993]. For $\mathrm{pCO}_{2}=400 \mathrm{ppmv}, \mathrm{S}=35 \%$, and $\mathrm{T}=17^{\circ} \mathrm{C}, \eta=0.831$. This implies that 0.83 moles of carbon are stored per mole of $\mathrm{H}^{+}$consumed, or 1.66 per mole of $\mathrm{Ca}^{2+}$ or $\mathrm{Mg}^{2+}$ added to the ocean.

The divalent cations present in carbonate minerals (e.g., $\left.\mathrm{CaCO}_{3}\right)$ mean that even weathering of carbonates can lead to removal of $\mathrm{CO}_{2}$ from the atmosphere. If carbonate minerals (e.g., in limestone) dissolve on land and subsequently re-precipitate, there is no net effect on $\mathrm{CO}_{2}$, but if the $\mathrm{Ca}^{2+}$ reaches the ocean, the resulting increase in alkalinity leads to uptake of $\mathrm{CO}_{2}$. Because the dissolution of $\mathrm{CaCO}_{3}$ releases a $\mathrm{C}$ atom, the net impact of such dissolution on $\mathrm{CO}_{2}$ uptake is smaller ( 0.4 to 0.7 ) than $\mathrm{Ca}^{2+}$ ions released from silicate weathering, but it is important to note the rather counter-intuitive fact that dissolving $\mathrm{CaCO}_{3}$ in seawater leads to uptake of $\mathrm{CO}_{2}$ from the atmosphere.

\subsection{The oceanic alkalinity cycle}



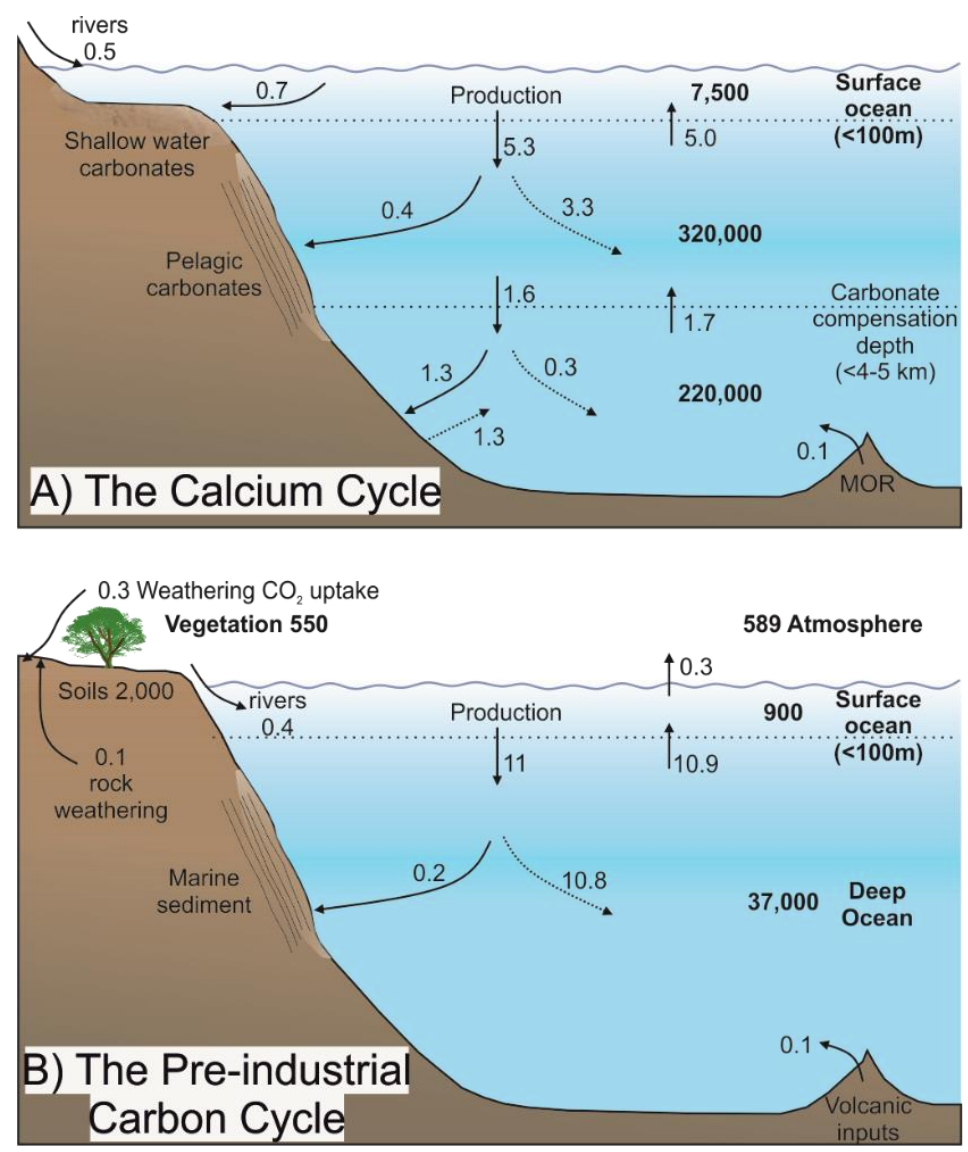

Figure 3: The global ocean A) calcium and B) pre-industrial carbon cycle. Adapted from Andersson [2014] and Sabine and Tanhua [2009]. Arrows represent fluxes in Gt Ca or Gt C per year $\left(\mathrm{a}^{-1}\right)$.

To a first approximation, the active oceanic cycle of alkalinity is that of $\mathrm{Ca}^{2+}$, and particularly the processes of formation and dissolution of $\mathrm{CaCO}_{3}$ (Figure $3 \mathrm{~A}$ ). Seawater in the surface ocean is supersaturated with respect to calcite by a factor of about 4 times (and aragonite by about 2.5 times), but the presence of other elements in seawater prevent inorganic precipitation of calcite in almost all oceanic settings [Berner 1975]. Many species of plant and animal have, however, developed chemical approaches to overcome this limitation and precipitate $\mathrm{CaCO}_{3}$ as calcite or aragonite, leading to removal of $\mathrm{Ca}^{2+}$ (and alkalinity) from the surface ocean. This removal occurs in the shallow water, neritic zone, particularly in large tropical reefs and carbonate platforms (e.g., corals, halimeda) and in the open ocean in planktonic ecosystems (e.g., coccolithophores, foraminifera). By removing alkalinity, biological production of $\mathrm{CaCO}_{3}$ from surface seawater leads to a flux of $\mathrm{CO}_{2}$ from the ocean to the atmosphere [Frankignoulle et al., 1994]. This is in contrast to the biological production of organic C (i.e. soft tissue), which causes subsequent ocean uptake of $\mathrm{CO}_{2}$.

The deep ocean is characterized by dissolution of $\mathrm{CaCO}_{3}$ and an increase in alkalinity (Figure $3 \mathrm{~B}$; and Andersson [2014]). Remineralization of settling organic $\mathrm{C}$ at depth releases $\mathrm{CO}_{2}$ and decreases the $\mathrm{pH}$ of seawater. This, coupled to a decrease in calcite solubility with increasing pressure, means that at some depth in the ocean, termed the calcite saturation horizon, water become undersaturated for calcite (Figure 4; [see Zeebe 2012]). At slightly greater depth - the lysocline - dissolution rates are sufficiently fast that sediment start to lose an appreciable fraction of the calcite settling from above. The depth at which dissolution of calcite removes 
virtually all calcite is termed the calcite compensation depth. This deep-ocean dissolution of $\mathrm{CaCO}_{3}$ leads to an increases in alkalinity of up to $10 \%$ relative to surface waters. It serves to partially neutralize the acidity generated by remineralization of organic matter; a process termed carbonate compensation [Ridgwell and Zeebe, 2005]. On timescales longer than the circulation of the ocean (i.e. $>1 \mathrm{ka}$ ), carbonate compensation alters the alkalinity of the whole ocean and acts as a natural buffer to offset changes in atmospheric $\mathrm{CO}_{2}$ created by imbalances elsewhere in the $\mathrm{C}$ cycle.

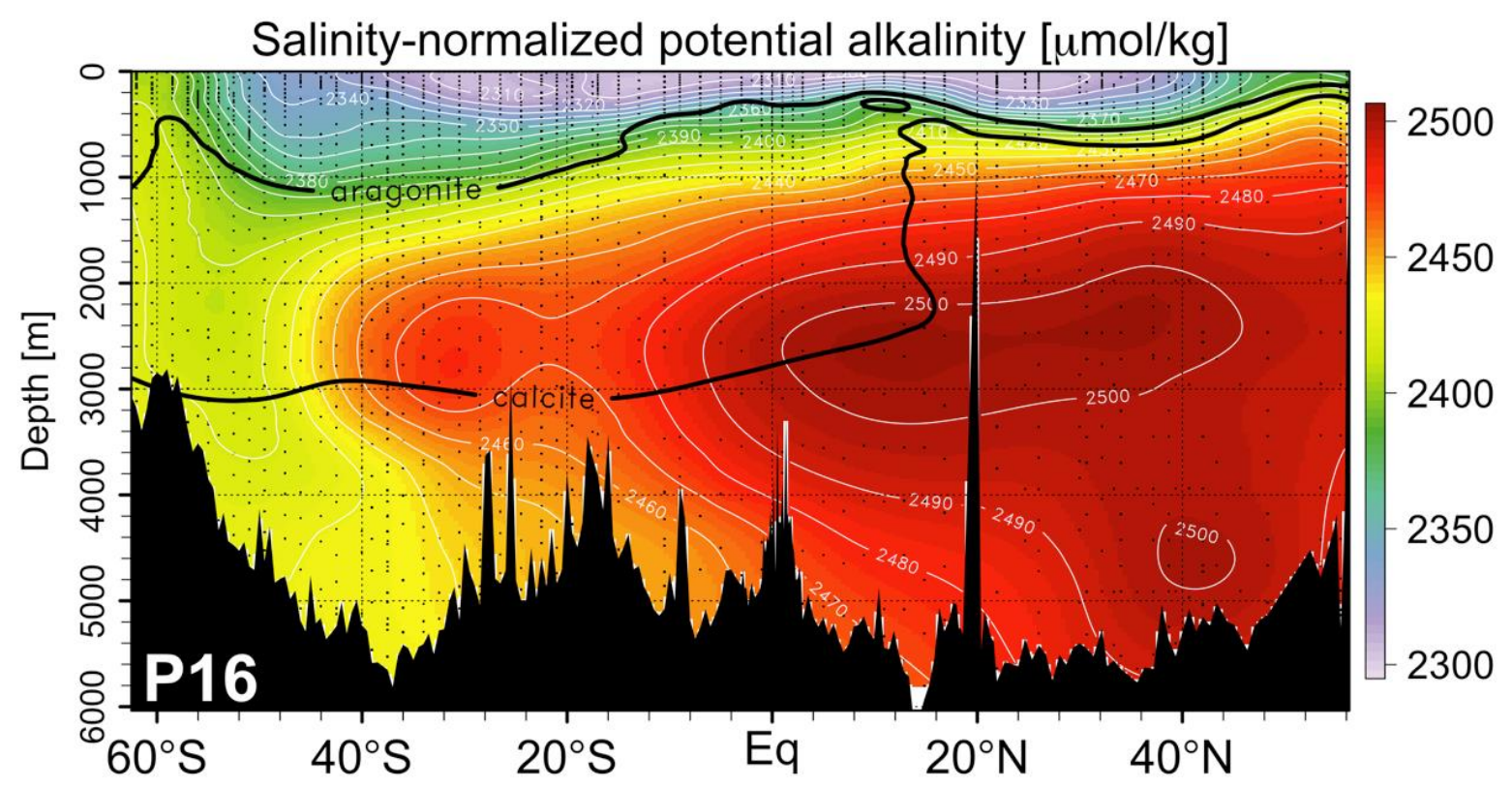

Figure 4: Salinity normalized potential alkalinity for the N-S P16 section in the central Pacific, defined according to Carter et al., [2014] and using the GLODAP dataset. Note the significant increase in deep waters, particularly in the north where waters have been isolated from the atmosphere for more than $1 \mathrm{ka}$, accumulating respired organic carbon from above, and dissolved $\mathrm{CaCO}_{3}$. Also shown are the depths of saturation for aragonite and calcite. Below these lines, the mineral is undersaturated (i.e. omega $<1$ ) and prone to dissolve. The lysocline and carbonate compensation depth - sedimentary features reflecting this change in saturation, are found slightly below the depth of calcite saturation. Units are microequivalents $\mathrm{kg}^{-1}$.

Upwelling of deep elevated alkalinity waters to the surface, which typically happens at high latitudes in the ocean, leads to surface variation in alkalinity of about $5 \%$ (Figure 5). Seasonal variation of up to 80-110 $\mu \mathrm{eq} \mathrm{kg^{-1 }}$ are also seen, resulting from changes in vertical mixing [Lee et al., 2006], riverine inputs [Cai et al., 2010], and especially primary production [WolfGladrow et al., 2007]. 


\section{Salinity-normalized potential alkalinity $[\mu \mathrm{mol} / \mathrm{kg}]$}

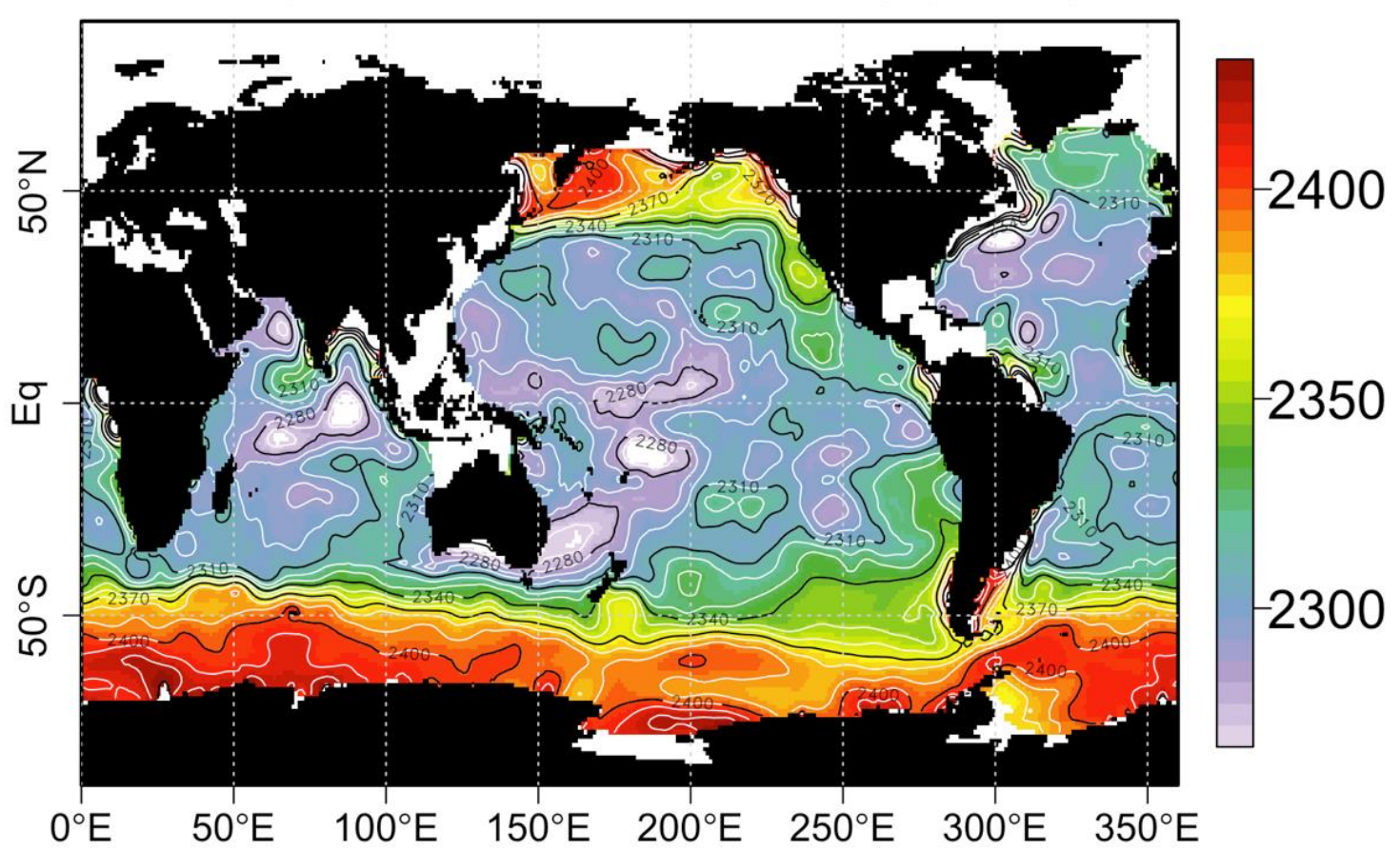

Figure 5: Salinity normalized alkalinity in the surface ocean (in microequivalents $\mathrm{kg}^{-1}$ ) showing the range and pattern of natural variation using the GLODAP dataset.

\subsection{The oceanic alkalinity cycle}

Imbalances between the input and removal fluxes of alkalinity can result in changes in global oceanic alkalinity and therefore the capacity of the ocean to store C. Such alkalinity-induced changes in partitioning of $\mathrm{C}$ between atmosphere and ocean are thought to play an important role in controlling climate change on timescales of 1 ka and longer [e.g., Zeebe 2012]. Through studying these natural changes in ocean alkalinity, it may be possible to constrain future changes in ocean chemistry from artificial changes in ocean alkalinity.

The oceanic residence time of $\mathrm{Ca}^{2+}$ with respect to riverine input is greater than $1000 \mathrm{ka}$ (Figure $3 \mathrm{~A}$ ), on which timescale the balance between volcanic degassing and sedimentary removal of $\mathrm{C}$ becomes a dominant control. So the major way in which alkalinity changes become important is changes in precipitation and particularly dissolution of $\mathrm{CaCO}_{3}$ (i.e. through carbonate compensation). Two time periods, (the Pleistocene and the Paleocene-Eocene) provide an indication of such processes.

Several processes may have led to higher ocean alkalinity during the glacial periods of the Pleistocene (e.g., the last glacial, $20 \mathrm{ka}$ ago). Such higher alkalinity would increase storage of $\mathrm{CO}_{2}$ in the ocean, and contribute to the decrease of atmospheric $\mathrm{pCO}_{2}$ known to be a significant cause of glacial cooling. One such process, operating in the surface ocean, is that lower glacial sea level would leave less continental shelf area for formation of carbonate reefs. The resulting decrease in $\mathrm{CaCO}_{3}$ precipitation, and probable erosion and dissolution of old reefs, would increase global ocean alkalinity [Opdyke and Walker 1992]. Another process, but operating in the deep ocean, stems from changes in ocean circulation in the Atlantic leading to sluggish 
deep waters containing substantially more re-mineralized $\mathrm{CO}_{2}$. This would lower deep-water $\mathrm{pH}$ to raise the lysocline, and thereby add alkalinity by dissolution of $\mathrm{CaCO}_{3}$ [Boyle 1988; Sigman et al., 2010].

Geochemical proxies have been developed to reconstruct past aspects of the ocean carbonate system, with two, measured in marine carbonates, seeing the greatest use: carbonate B isotope composition systematically reflects changing concentrations of $\mathrm{B}$ species with $\mathrm{pH}$, and an empirical relationship is observed between carbonate $\mathrm{B} / \mathrm{Ca}$ and the concentration of $\mathrm{CO}_{3}{ }^{2-}$. Application of such proxies has been used to reconstruct past ocean carbonate chemistry. One such study indicates higher alkalinity in the glacial ocean [Rickaby et al., 2010], though this is not observed in all ocean regions [Zeebe and Marchitto 2010]. No single model is yet accepted to explain glacial-interglacial atmospheric $\mathrm{pCO}_{2}$ cycles, but it is clear that the $\mathrm{CO}_{2}$ removed from the atmosphere during glacials was stored in the ocean. Alkalinity changes may have played a role in this storage (see Sigman and Boyle [2000] for a summary of glacial-interglacial $\mathrm{pCO}_{2}$ mechanisms).

A second example of the role of ocean alkalinity in the global carbon cycle is provided by an abrupt warm period $56 \mathrm{Ma}$ ago; the Paleocene-Eocene Thermal Maximum (PETM). This event is thought to have been triggered by a massive release of $\mathrm{C}$ to the ocean-atmosphere system (>2,000 Gt C) probably from catastrophic breakdown of methane clathrates [Archer et al., 2009]. Although the source of the $C$ differs, this rapid $C$ release is widely seen as a useful analogue for the likely response of the Earth system to present-day anthropogenic $\mathrm{C}$ release [McInerney and Wing 2011]. At the PETM, the large increase in $\mathrm{CO}_{2}$ in the ocean resulting from $\mathrm{C}$ release led to significant decreases in ocean $\mathrm{pH}$ and shoaling of the lysocline to increase ocean alkalinity [Zachos et al., 2005]. This carbonate compensation buffered a significant fraction of the change in $\mathrm{CO}_{2}$ and occurred on a timescale of $<10,000$, short geologically, but still a slow response relative to human timescales. The controls of atmospheric $\mathrm{CO}_{2}$ on glacial/interglacial time periods are reviewed by PAGES [2016] and Archer et al., [2000].

\section{Modeling elevated alkalinity}

The importance of the carbon cycle for climate ensures that a wide range of models have been developed to understand and predict its operation. These range from simple box models to highly sophisticated carbon components to general circulation models. These models can be used to provide information about the likely impact of intentional addition of alkalinity to the oceans.

\subsection{Box models}

At its very simplest, the ocean can be modeled as a single box to consider the scale of change on the natural system required to uptake significant amounts of anthropogenic $\mathrm{CO}_{2}$. Assuming addition of $\mathrm{Ca}^{2+}$ : adding one mole of $\mathrm{Ca}^{2+}$ to a single-box ocean causes an increase in $\mathrm{HCO}_{3}{ }^{-}$ and $\mathrm{CO}_{3}{ }^{2-}$ and the uptake of $\approx 1.7$ moles of $\mathrm{CO}_{2}$ (see section 2.3). Addition of sufficient $\mathrm{Ca}^{2+}$ to fully compensate for present anthropogenic emission of $10 \mathrm{Gt} \mathrm{C} \mathrm{a}^{-1}$ therefore requires addition of $20 \mathrm{Gt} \mathrm{Ca}^{2+} \mathrm{a}^{-1}$. This is $\approx 20$ times the annual riverine input of $\mathrm{Ca}^{2+}$, a very significant perturbation, and obviously a very substantial undertaking in engineering terms. The large volume of the ocean and its high $\mathrm{Ca}^{2+}$ concentration, however, mean that the oceanic perturbation is very much smaller and only a 0.9 mmoles $\mathrm{kg}^{-1}$ increase in $\mathrm{Ca}^{2+}$ is required. Even if considering the surface ocean alone this annual addition is less than a $0.3 \%$ increase in 
total $\mathrm{Ca}^{2+}$. This simple one-box approach demonstrates the possibility of substantial uptake of $\mathrm{C}$ to the ocean with relatively small changes in the ocean, but also the scale of the effort required to effect significant alkalinity addition.

At the next level of sophistication, models which divide the ocean into a small number of boxes can be used to assess changes caused by continued addition of ocean alkalinity. An example is shown in Figure 6, which imposes the 20-fold increase to riverine alkalinity fluxes, as required to compensate for $10 \mathrm{Gt} \mathrm{C} \mathrm{a}^{-1}$ anthropogenic emissions, for 300 years. Such a model demonstrates the expectation that long-term alkalinity addition could compensate for anthropogenic $\mathrm{C}$ addition, and could prevent the associated decrease in ocean $\mathrm{pH}$. They also show the scale of change in alkalinity in the surface and deep ocean that results from this intervention, and the significant changes in lysocline depth that arise both from anthropogenic C emission, and from alkalinity addition. Paquay and Zeebe [2013] used a slightly more complex model with 10 boxes (for the surface, intermediate and deep ocean for the 3 largest ocean basins and the high latitudes) to investigate the impact of adding alkalinity across the entire surface ocean to totally compensate for various carbon emission scenarios. In that study, sufficient alkalinity was added to exactly compensate for $\mathrm{pH}$ changes imposed by fossil fuel addition, which was possible even in their largest emission scenario (compensating for 5,000 Gt $\mathrm{C}$ over 500 years) by adding up to $15 \mathrm{Gt} \mathrm{Ca}^{2+} \mathrm{a}^{-1}$ ). 


\section{No added alkalinity}
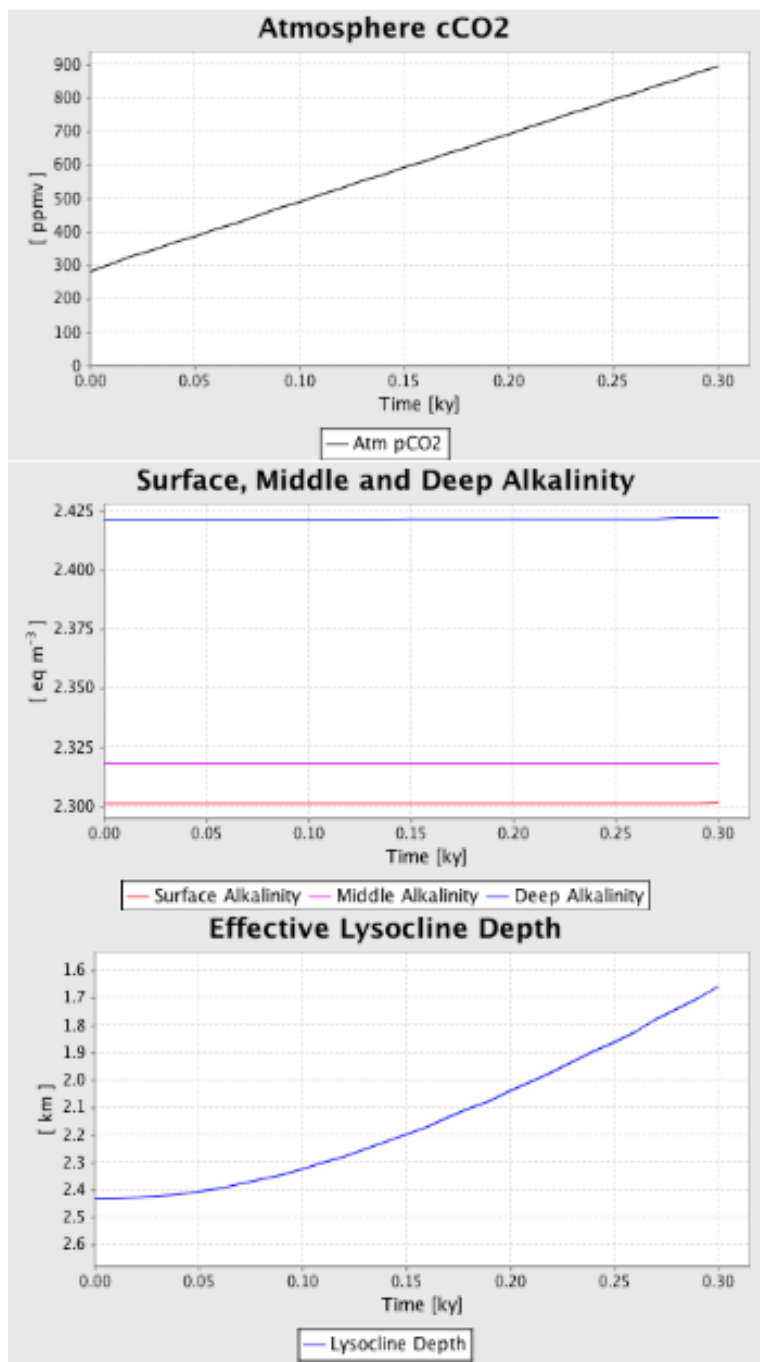

Surface, Deep pH
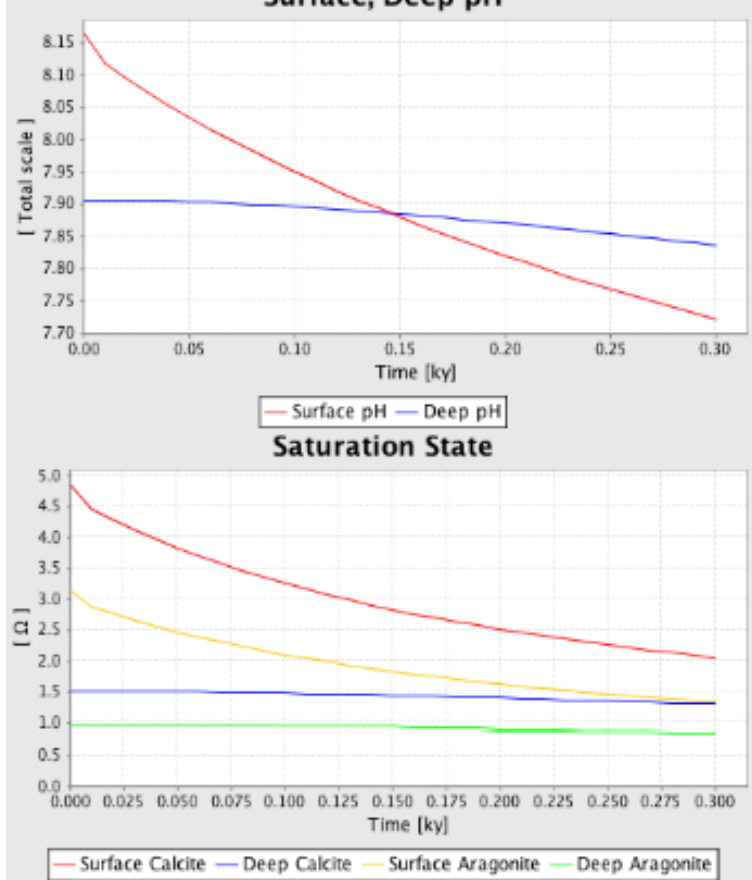

\section{With added alkalinity}

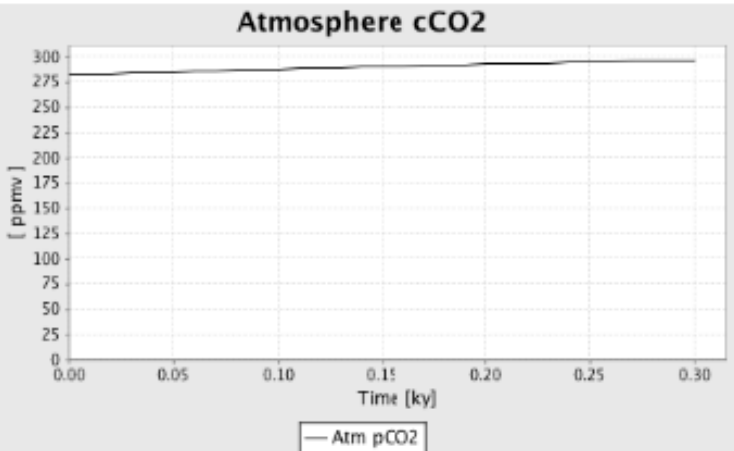

Surface, Middle and Deep Alkalinity
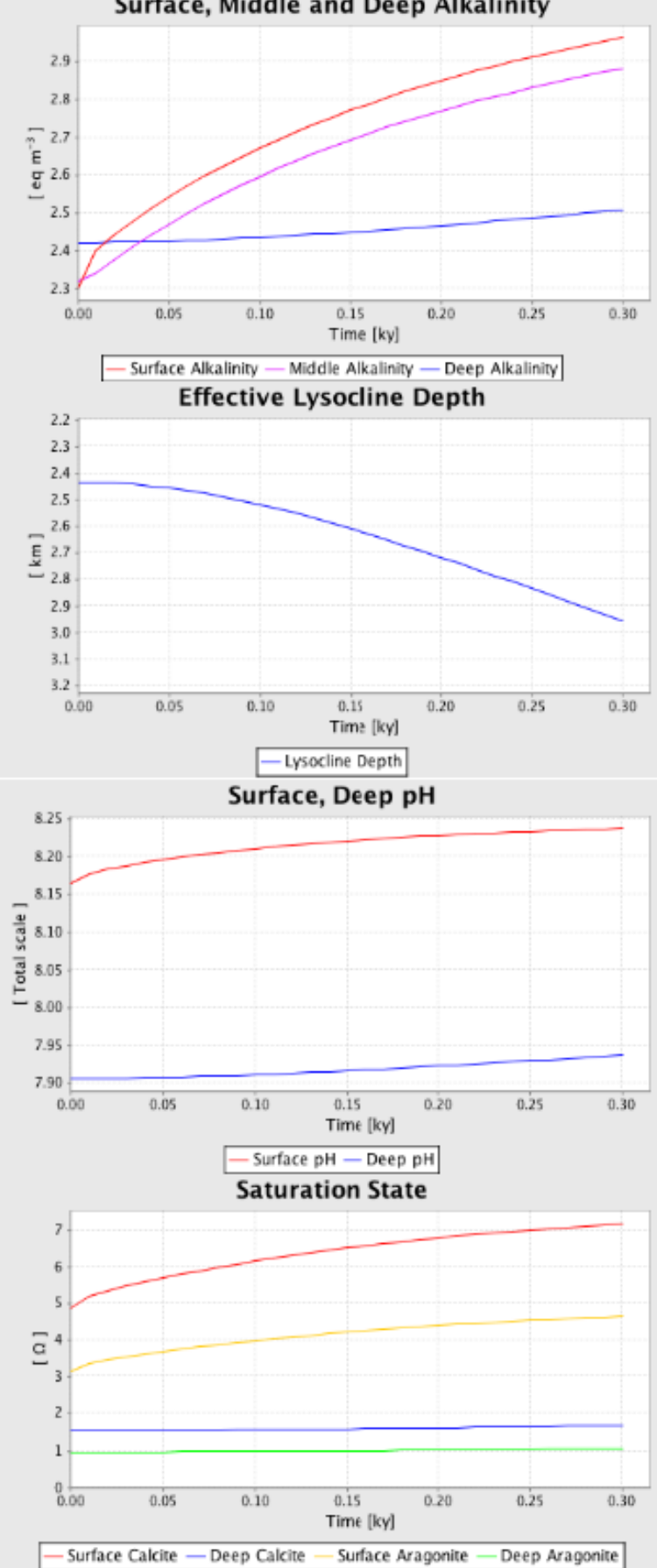
Figure 6: Output from a 3-box model mimicking significant features of the ocean carbon system (http://www.noc.soton.ac.uk/jmodels/; Chuck et al., [2005]). Left hand panels take an initially equilibrium carbon cycle and perturbs it with a sufficient $\mathrm{C}$ flux to cause a $2 \mathrm{ppmV}$ increase in atmospheric $\mathrm{CO}_{2} \mathrm{a}^{-1}$, approximately equivalent to today's rate of $\mathrm{CO}_{2}$ rise. Right hand panels impose the same $\mathrm{C}$ flux, but also increase the riverine alkalinity flux by a factor of 20 to increase $\mathrm{C}$ uptake to the ocean. Note that scales are not identical in left and right panels. The increased alkalinity flux in the right hand panels prevents the significant changes in atmosphere $\mathrm{CO}_{2}$ and ocean $\mathrm{pH}$ seen in the left-hand figures. The right hand panels also illustrate the long-term effects on ocean saturation due to continued addition of alkalinity.

These model results were previously presented in Henderson et al., [2008].

\subsection{Spatially resolved models}

To more completely mimic the ocean response to addition of alkalinity, ocean models with high spatial resolution which capture both ocean circulation and the operation of the carbon cycle can be used. Ilyina et al., [2013], for instance, used the Hamburg Ocean Carbon Cycle Model to simulate the response to the addition of sufficient alkalinity to counteract all anthropogenic emissions from the 'business as usual' A1B baseline scenario $(\approx 1,400 \mathrm{Gt}$ C by 2100 ). This model assumed addition in particular patches of the surface ocean, equivalent to one seventh of the ocean surface, and was able to assess the distribution of alkalinity and its effects into the global ocean (Figure 7). Alkalinity increased, as expected, to between 2.3 and $3.0 \mathrm{mEq} \mathrm{kg}{ }^{-1}$ for most of the ocean, but rising up to $5.5 \mathrm{mEq} \mathrm{kg}{ }^{-1}$ in the north Atlantic and North Pacific where alkalinity addition was imposed. Similarly, $\mathrm{pH}$ was generally returned to values similar to pre-industrial in much of the ocean, but was elevated around application regions, and calcite saturation similarly increased $\left(\Omega_{\text {calcite }} \approx 20\right)$. As for the simple box models, this spatially-resolved modeling, indicates the general success of alkalinity addition in generating ocean uptake of $\mathrm{CO}_{2}$, but highlights clearly the challenges imposed by extreme ocean changes (e.g., elevated $\mathrm{pH}$ and carbonate saturation) in regions of alkalinity addition. 

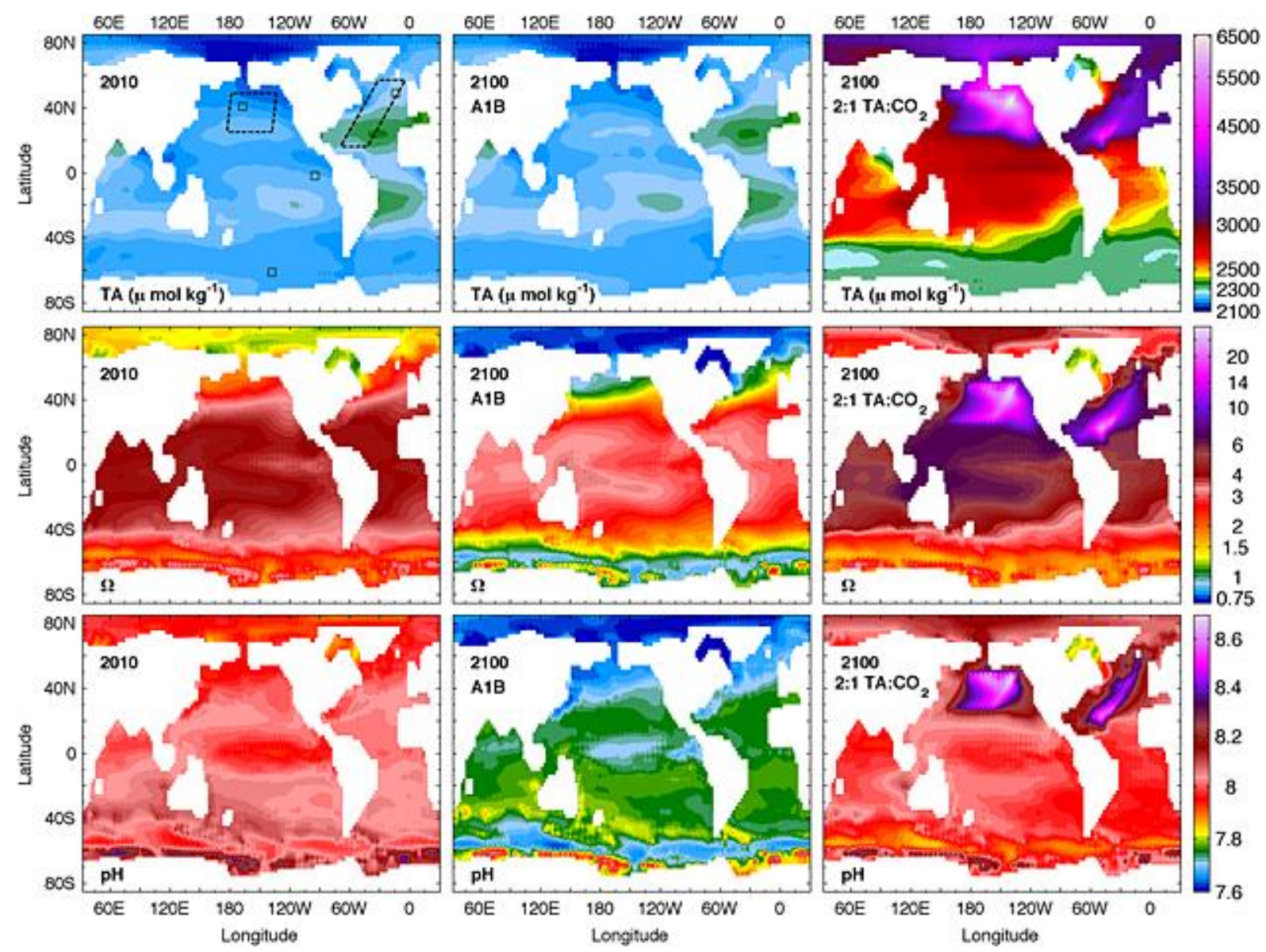

Figure 7: Model results to demonstrate the impact of alkalinity addition to one seventh of the surface ocean. Reprinted by permission from John Wiley Sons, Inc: Geophysical Research Letters [Ilyina et al., 2013], copyright @ 2013. Surface maps of alkalinity (top row), $\Omega_{\text {calcite }}$ (middle row) and $\mathrm{pH}$ (bottom row) are shown for three scenarios: 2010 (left column); 2100

following $\mathrm{A} 1 \mathrm{~B} \mathrm{CO}_{2}$ emission (middle column); 2100 with addition of alkalinity (right column). The dashed boxes in the upper left panel show the regions of alkalinity addition. Note that ocean saturation and $\mathrm{pH}$ are returned to broadly 2010 levels by alkalinity addition, but that there are very large changes in the system in the North Atlantic and North Pacific around the sites of alkalinity addition

Subsequent studies have also used full ocean models to assess the impact of alkalinity addition. Ferrer-Gonzalez and Ilyina [2016] used a fully integrated Earth System Model and added sufficient alkalinity to compensate emissions from RCP8.5 to a level congruent with RCP4.5. Despite imposing a uniform distribution of alkalinity addition, the ocean response was more marked in some regions, notably the Arctic, where $\mathrm{pH}$ climbed to 8.6 and $\Omega_{\text {calcite }} \approx 10$, and the tropics where $\Omega_{\text {calcite }}$ was also high. Keller et al., [2014] (using the UVic model) also imposed a uniform alkalinity addition, but limited the amount of addition to that which could be delivered by modern ship fleets $\left(\approx 6 \mathrm{Gt} \mathrm{Ca}^{2+} \mathrm{a}^{-1}\right.$ as $\mathrm{Ca}(\mathrm{OH})_{2}$ added by uniformly increasing total alkalinity). This level of addition created only modest uptake of $\mathrm{CO}_{2}$ from the atmosphere (166 Gt C by $2100 ; ~ 8 \%$ of the A1B/RCP8.5 emissions scenario). While the ocean system was relatively unperturbed in this model, it powerfully illustrates the engineering difficulty inherent in delivering the very large amounts of alkalinity required to compensate for any significant 
fraction of emitted $\mathrm{CO}_{2}$. It is likely that alkalinity addition could not be the sole mechanism used for any substantial negative emissions approach, but would be part of a portfolio of measures.

Most models of alkalinity addition do not specify the chemical added to generate change, or assume pure $\mathrm{Ca}(\mathrm{OH})_{2}$, which is effectively "pure" alkalinity. Real world application of alkalinity might, however, be pursued by addition of a particular mineral. Köhler et al., [2013] investigated one such scenario by using a biogeochemical model to assess the impact of direct addition of olivine to the ocean surface. Olivine (forsterite rich, $\mathrm{Mg}_{2} \mathrm{SiO}_{4}$ ) dissolution increases total alkalinity with a molar 1:4 olivine/alkalinity ratio) but also releases silicon. The authors force their model with a range of olivine addition scenarios (from 1 to $10 \mathrm{Gt} \mathrm{a}^{-1}$ ) for localized (ship) and global distribution scenarios. Surprisingly, while there is elevated alkalinity, the model predicts a decrease in $\mathrm{CaCO}_{3}$ export and an increase in organic carbon export due to the fertilization effect of dissolved silica on diatoms. Natural silica flux into the ocean is approximately $170 \mathrm{Mt}$ of $\mathrm{Si} \mathrm{a}^{-1}$ (e.g., from riverine input) [Tréguer et al., 1995]. There would be approximately $200 \mathrm{Mt}$ of Si released for every Gt of olivine added to the ocean, so it is not surprising that a significant fertilization effect is observed. Olivine also contains iron (as fayilite, $\mathrm{Fe}_{2} \mathrm{SiO}_{4}$ ), which may also fertilize biological activity. Hauck et al., [2016] suggests that theoretically around $0.6 \mathrm{Gt} \mathrm{C} \mathrm{a}^{-1}$ could be sequestered for every $\mathrm{Gt} \mathrm{a}^{-1}$ of olivine added to the surface ocean, with $57 \%, 37 \%$, and $6 \%$ of the effect coming from alkalinity, iron, and silicon respectively. A complication in this relates to the rate of olivine dissolution required, which are assumed to be instant and complete in the modeling. If $\mathrm{CO}_{2}$ is removed from the atmosphere, terrestrial carbon sinks would release $\mathrm{CO}_{2}$ [e.g., Vichi et al., 2013]. This 'rebound' together with emissions from material extraction, processing and transport would also diminish the net sequestration potential of this and other alkalinity addition approaches

The handful of modeling studies investigating an intentional increase of ocean alkalinity have been useful in broadly defining the relationship between carbon sequestration extent and the impact on the ocean carbonate system. Figure 8 shows the range of pathways from these models in $\Omega-\mathrm{pCO}_{2}$ space. This figure shows the decrease in $\Omega_{\text {calcite }}$ that has already occurred due to anthropogenic $\mathrm{CO}_{2}$ emissions, and the further decrease expected as $\mathrm{CO}_{2}$ emissions continue. Alkalinity levels are depicted by the contours (the shaded region representing levels in the modern ocean), and the impact of various model scenarios on this alkalinity.

The models shown on this figure demonstrate the potential advantages to ocean saturation state of alkalinity addition. For instance, some studies suggest increased risk to coral ecosystems

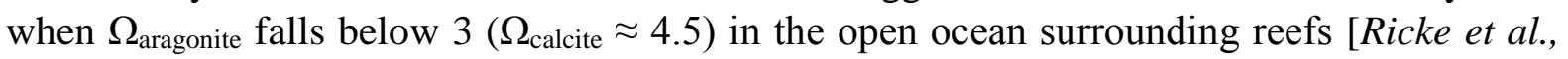
2013]. These ecosystems generally occupy waters with elevated carbonate saturation, so their fate may be visualized in Figure 8 by the future trajectory of the upper part of the shaded box. By increasing saturation state, alkalinity addition could keep the ocean at a saturation state conducive to continued coral reef health. 


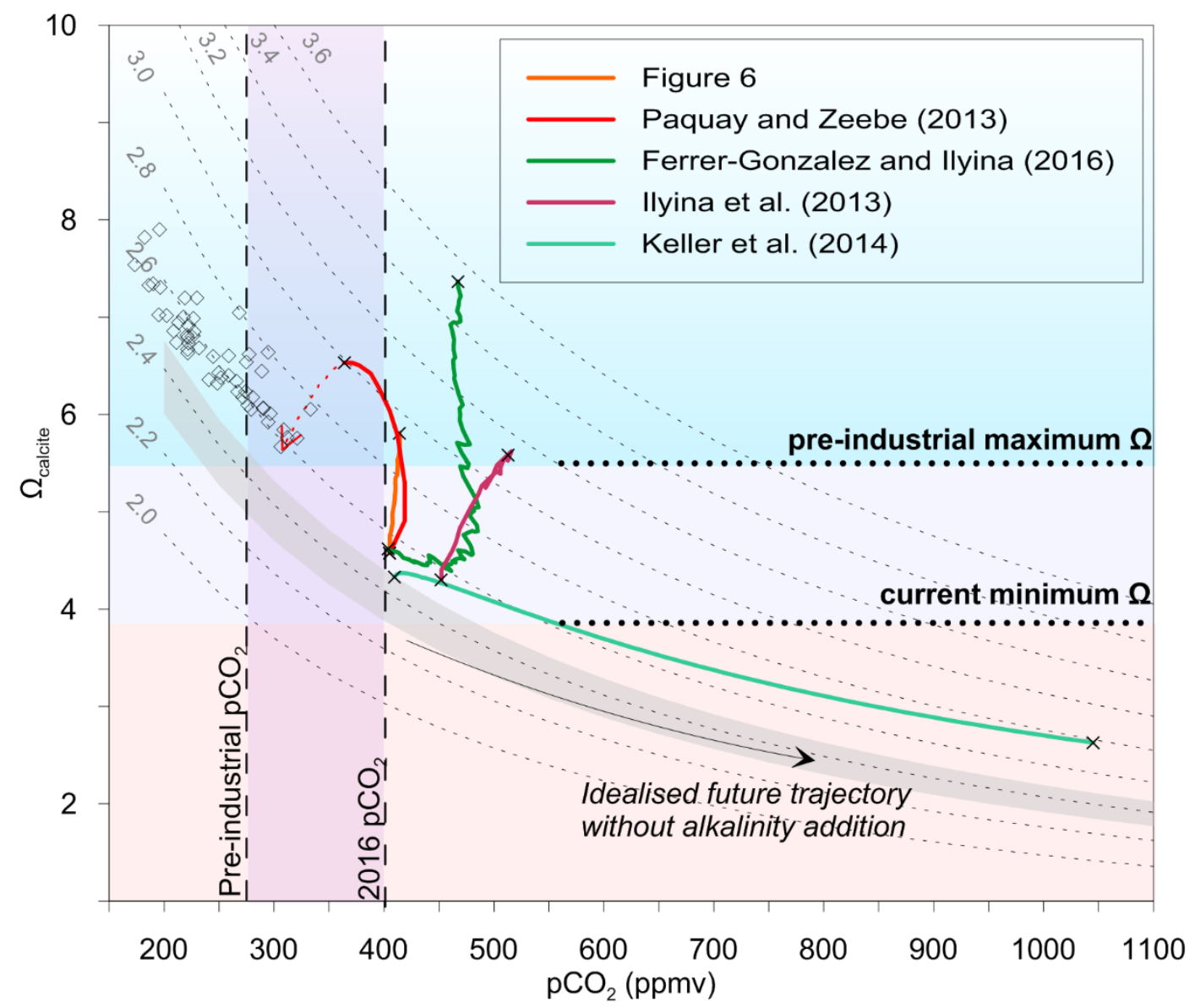

Figure 8: Results from modeling studies showing the relationship between $\Omega_{\text {calcite }}$ and $\mathrm{pCO}_{2}$ for various alkalinity addition scenarios [Ferrer-González and Ilyina 2016; Ilyina et al., 2013; Keller et al., 2014; Paquay and Zeebe 2013]. The contours represent average surface ocean $\left(0-100 \mathrm{~m}\right.$ depth) $\mathrm{A}_{\mathrm{T}}$ in $\mathrm{mEq} \mathrm{kg} \mathrm{kg}^{-1}$ at $16^{\circ} \mathrm{C}$ and $35 \%$ salinity, and the hatched region represents the 2 s.d. about the mean of modern surface ocean alkalinity. The open symbols represent ocean conditions reconstructed from Hönisch et al., [2009] for the past 2 Ma.

\section{Longevity of carbon storage}

\subsection{The saturation state of carbonate minerals in the ocean}

The residence time of dissolved inorganic carbon in the whole ocean is around $100 \mathrm{ka}$, which would effectively form a permanent storage reservoir on human timescales. However, this may decrease if alkalinity is reduced by increased formation and export of carbonate minerals from the surface ocean. Given that seawater is already supersaturated with respect to some magnesium and calcium carbonate minerals (see Table $\mathrm{S} 1$ in supporting information), it is intuitive to think that any additional alkalinity would precipitate out of solution. However, spontaneous nucleation is strongly inhibited in seawater, and carbonate production is thought to be largely biologically controlled, although there is no estimate of the relative proportions. This section considers what controls carbonate production in the ocean, and how this may change if alkalinity was intentionally increased.

Through transport, mixing, and export, elevated alkalinity at the surface will also eventually have an impact on conditions in the interior ocean. Elevated alkalinity in the water column will increase the carbon compensation depth $(\mathrm{CCD}$; the depth in the oceans at which calcite 
dissolves quicker than it is supplied; [Ridgwell 2007]). A deeper CCD will lead to an increase in the extent of sediment exposed to elevated saturation states, and notionally an increase in calcification and export, and thus increase the net removal of $\mathrm{CaCO}_{3}$ from the ocean. This partially undoes the effect of adding alkalinity. However some of this alkalinity will eventually be returned to the surface through upwelling. This effect is therefore a long-term negative feedback. However, it is unlikely to completely reverse the effectiveness of alkalinity input because the fluxes of carbonate in the natural cycle are smaller than those that those required on human timescales. Barker et al., [2006] suggest that elevated organic carbon export associated with carbonate production at the surface, may offset any $\mathrm{CO}_{2}$ release, either through sequestration of organic carbon into sediments/interior ocean, or through enhanced dissolution of sediments from increased oxidation of organic carbon.

It is critical for the assessment of carbon storage due to ocean alkalinity to understand its overall impact on the carbon cycle, particularly on carbon production and export. The following sections present an overview of biological and abiotic controls of carbonate formation in the ocean.

\subsection{Biological carbonate precipitation and dissolution}

Carbonate precipitation is a key feature in the physiology of a large number of ocean dwelling organisms [Addadi et al., 2006; Müller 2011]. Distinction is often made between pelagic (e.g., coccolithophores, foraminifera, pteropods/heteropods) and benthic (e.g., corals, molluscs, and crustaceans) calcifiers. Figure 9 shows the typical morphology of a coccolithophore and foraminifera. There is considerable variation in the mechanisms of calcification [Müller, 2011] which result in species/genus variability to environmental stimuli. As such, research investigating species and ecosystem response to ocean acidification has produced variable results [Ries et al., 2009]. Generally, species that are more efficient at maintaining $\mathrm{pH}$ in the internal environment in which they calcify are less affected by changes in carbonate chemistry of the ambient environment.
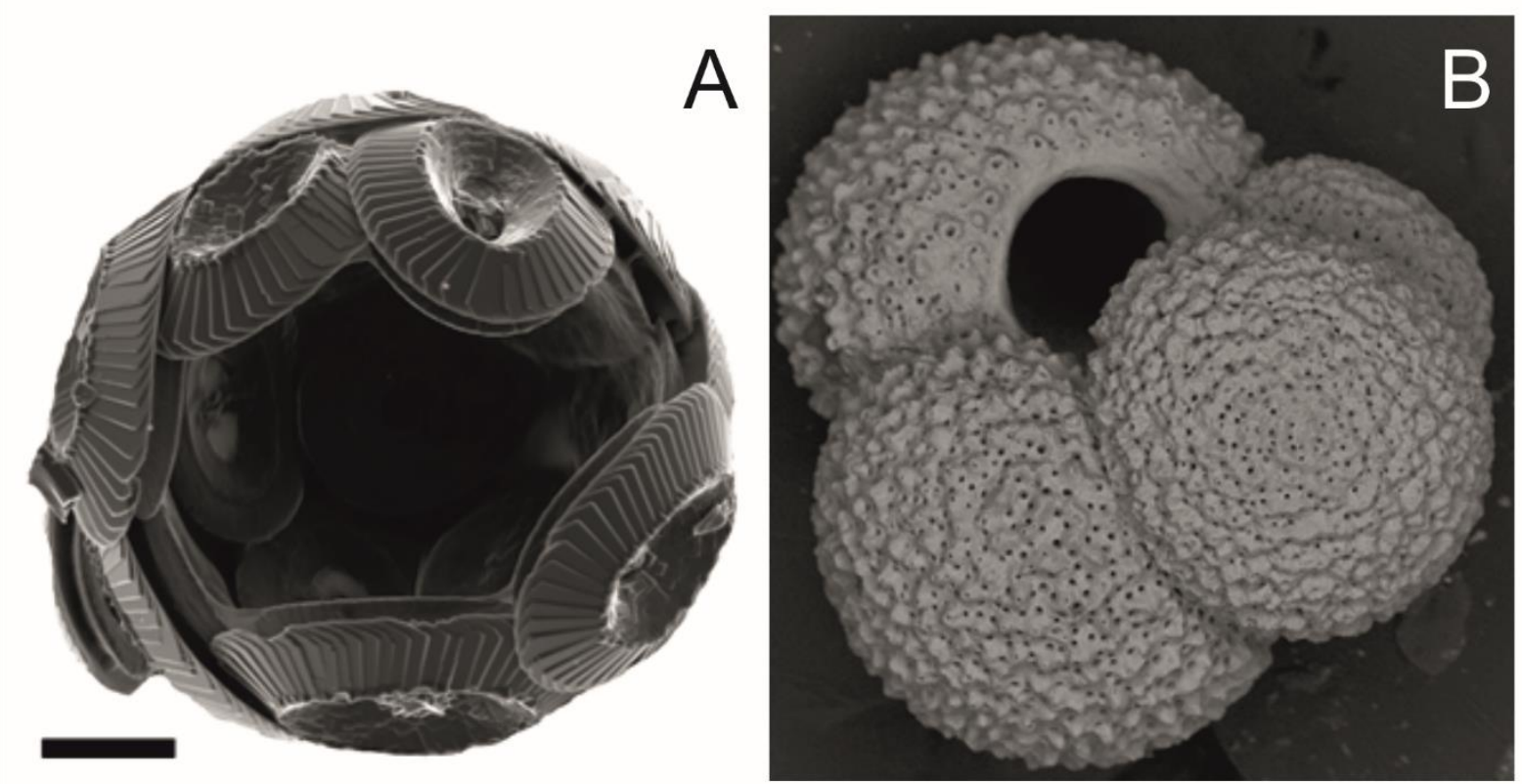
Figure 9: Scanning electron microscope images of A) A coccolithophore Coccolithus pelagicus ssp. Braarudii and B) a foraminifera Globigerina bulloides. Courtesy of Michaël

Hermoso (University of Oxford). Approximate width is $10 \mu \mathrm{m}$ and $30 \mu \mathrm{m}$ for A and B respectively

Elevated $\mathrm{CO}_{2}$ in the atmosphere lowers $\left[\mathrm{CO}_{3}{ }^{2-}\right]$ in the ocean, which puts stress on shell forming organisms ('ocean acidification'). Extensive research has been conducted over the last 20 years to understand the impact of ocean acidification on marine biota and the global carbon cycle [Doney et al., 2009]. Most of this research omits the investigation of elevated saturation states (e.g., Figure 10, which is not exhaustive, but indicative), and primarily focuses on manipulating $\left[\mathrm{CO}_{2}(\mathrm{aq})\right]$ rather than alkalinity.

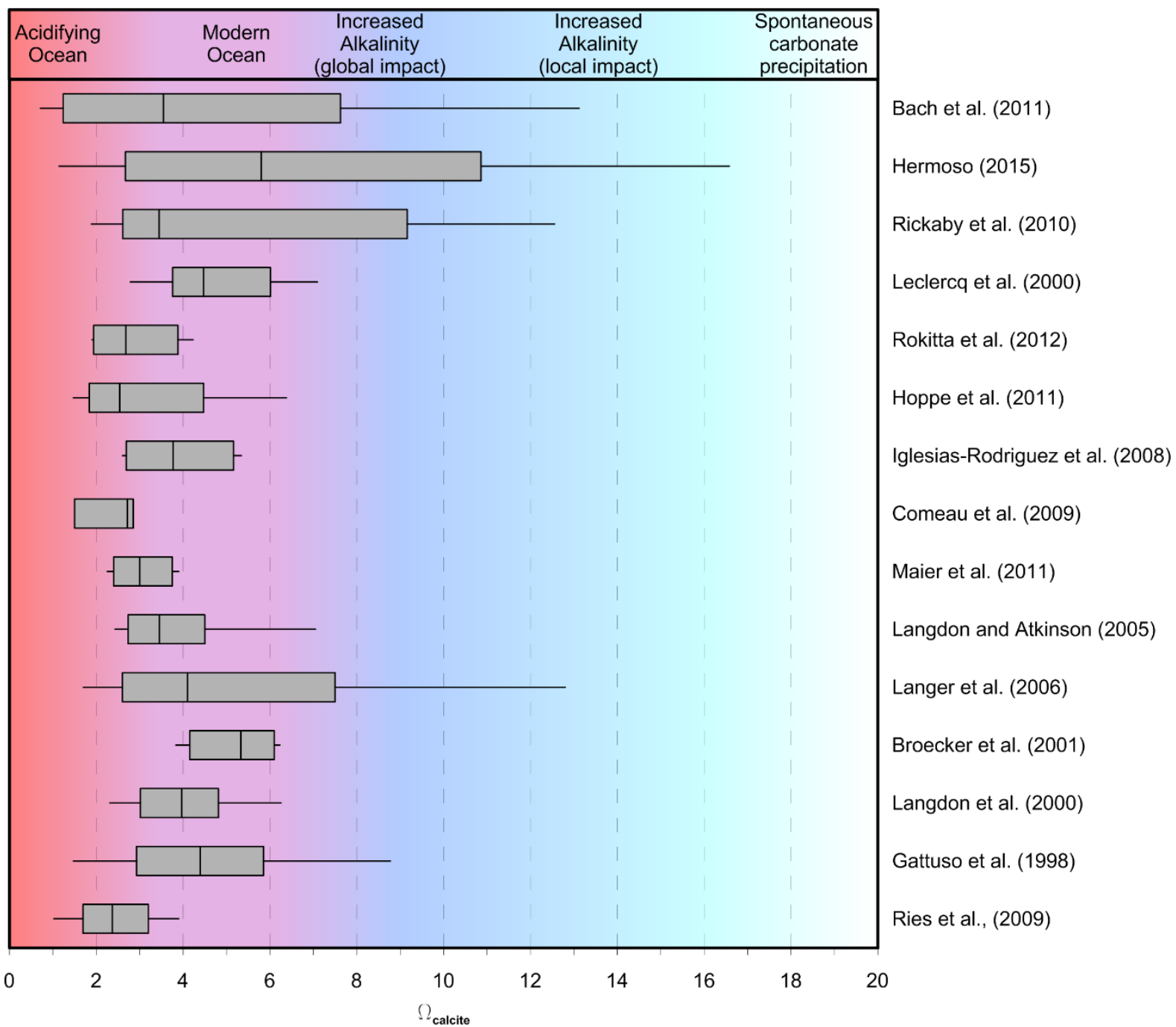

Figure 10: Indicative $\Omega_{\text {calcite }}$ ranges of culture experiments investigating calcification rate. [Bach et al., 2011; Broecker et al., 2001; Comeau et al., 2009; Gattuso et al., 1998; Hermoso 2015; Hoppe et al., 2011; Iglesias-Rodriguez et al., 2008; Langdon et al., 2000; Langdon and Atkinson 2005; Langer et al., 2006; Leclercq et al., 2000; Maier et al., 2011; Rickaby et al., 2010; Ries et al., 2009; Rokitta et al., 2012].

Phytoplanktonic calcifiers are responsible for a considerable proportion of particulate inorganic carbonate production in the surface ocean. They produce carbonate minerals in controlled microenvironments within the cell [Marsh 2003]. By regulating the concentration of $\mathrm{Ca}^{2+}, \mathrm{CO}_{2}$ 
and $\mathrm{pH}$ they can express a high degree of control on the internal saturation state of carbonate minerals. The response of these organisms to an acidifying ocean has been well studied (references in Figure 10). However fewer studies investigate the impact of elevated alkalinity on calcification rate. Langer et al., [2006] investigated a wide range of aqueous carbon dioxide levels by the addition of hydrochloric acid or sodium hydroxide in a closed single species culture experiment ( $\Omega_{\text {calcite }}$ from 2 to $13, \mathrm{pH} 7.8$ to 8.7 ). They measured the cellular carbon content of Calcidisus leptoporus and Coccolithus pelagicus (important primary producing coccolithophore species). Both species showed a reduction in calcification at elevated calcite saturation, possibly in response to lower concentrations of aqueous $\mathrm{CO}_{2}$. As ocean acidification is concerned largely with $\left[\mathrm{CO}_{2}(\mathrm{aq})\right]$ and the resulting decrease in $\left[\mathrm{CO}_{3}{ }^{2-}\right]$, it is difficult to interpret ocean acidification results for ocean alkalinity carbon storage, which would promote a different relationship between $\left[\mathrm{CO}_{2}(\mathrm{aq})\right]$ and $\left[\mathrm{CO}_{3}{ }^{2-}\right]$. For instance, it is possible to modify dissolved inorganic carbon (DIC) while maintaining constant $\mathrm{pH}$ to create conditions in which $\mathrm{pCO}_{2}$ and $\Omega_{\text {calcite }}$ are simultaneously elevated [Rickaby et al., 2010]. In these experiments there was little change in particulate inorganic carbon production (for Gephyrocapsa oceanica and C. pelagicus at $\mathrm{pCO}_{2}=1,800 \mathrm{ppmv}$, and $\Omega_{\text {calcite }}=13$ ), whereas variations in organic carbon fixation were detected. However, Hermoso [2015] demonstrated a parabolic relationship between $\mathrm{pH}$ (and $\Omega$ ) and growth rate for the same species. The results in Bach et al., [2011] for Emiliania huxleyi are highly relevant to ocean alkalinity addition. By undertaking two experimental regimes in which $\mathrm{pCO}_{2}$ is manipulated while allowing $\mathrm{pH}$ to vary or maintaining it at a constant value, the results decouple the impact of $\mathrm{A}_{\mathrm{T}}$ and $\left[\mathrm{CO}_{2}\right]$ on inorganic carbon production, and suggest a plateau at around $\mathrm{A}_{\mathrm{T}}=4.9 \mathrm{mEq} \mathrm{kg}^{-1}$.

Although coral reefs constitute only a small proportion of the ocean they are responsible for up to $50 \%$ of the global $\mathrm{CaCO}_{3}$ production [Mackenzie and Andersson 2013; Smith and Kinsey 1976]. Species of coral express a wide degree of control on the chemistry of their calcifying fluids. Those that have little control generally follow an abiotic relationship between $\Omega$ and calcification rate (Figure 11, see below). Whereas, some coral species have evolved a capacity for buffering against lower $\Omega$ [McCulloch et al., 2012]. The response of corals to elevated saturation states is poorly constrained. While corals are responsible for carbonate production, they are also the site for dissolution (e.g., through raised $\mathrm{pCO}_{2}$ from respiration). Generally, the rate of dissolution follows an abiotic relationship with $\Omega$, which will likely be impeded by elevated alkalinity. Schneider et al., [2011] investigated the response of Stichopus herrmanni and Holothuria leucospilota (species of sea cucumber) in chemically isolated incubation experiments. These species dissolve calcium carbonate particles within their digestive tract and secrete solutions with elevated levels of alkalinity. In these experiments, alkalinity levels increased by around 0.1 and $0.05 \mathrm{mEq} \mathrm{kg}^{-1}$ for $S$. Herrmanni and H. leucospilota respectively (70-85\% due to the accelerated dissolution of carbonate, the remainder due to ammonia secretion). The dissolution of carbonate minerals is an important component of the natural carbon cycle $\left(0.1-0.2 \mathrm{Gt} \mathrm{C} \mathrm{a}^{-1}\right)$, which may be impacted by elevated alkalinity. 


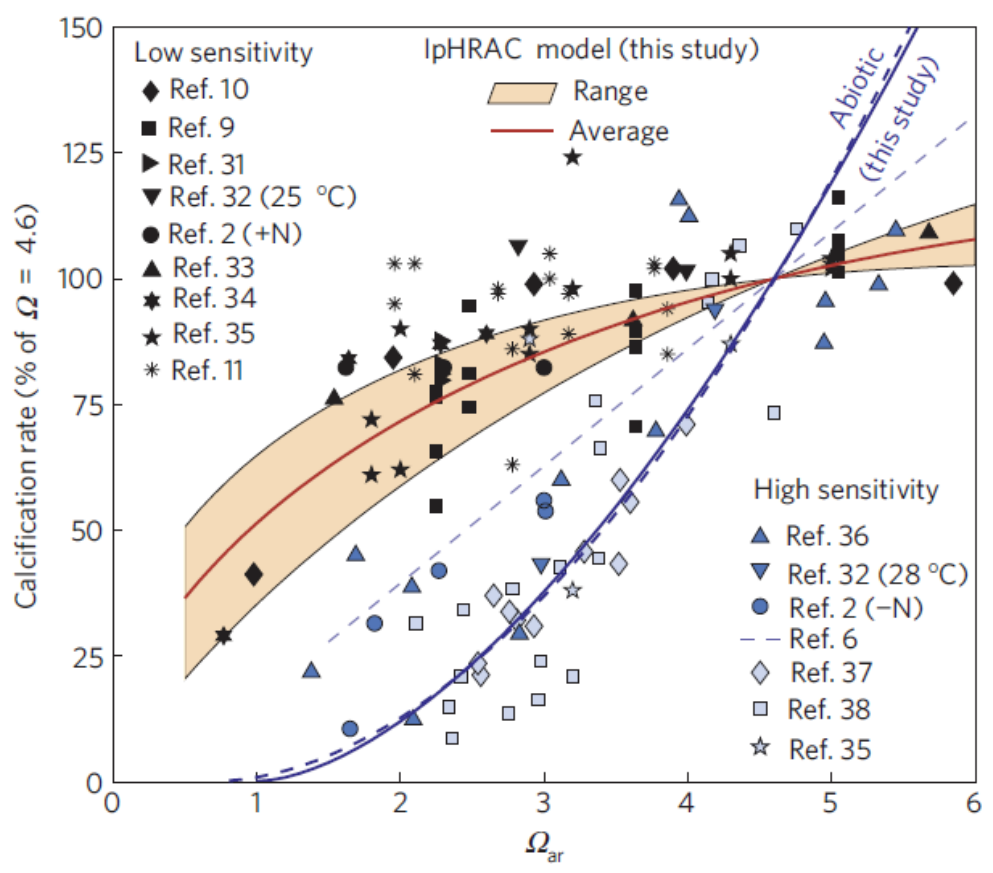

Figure 11: Percentage change in calcification rates (relative to $\Omega=4.6$ ) plotted against seawater aragonite saturation states . Reprinted by permission from Macmillan Publishers Ltd: Nature Climate Change [McCulloch et al., 2012], copyright ( 2012 . For embedded figure references see McCulloch et al., [2012].

Some paleoclimate research attempts to correlate the shell mass or density of marine organisms to the carbonate chemistry of the oceans. Such a record of past calcification rates are important for understanding the potential effects of ocean acidification, but could also be useful for constraining the stability of elevated alkalinity. For instance, Barker and Elderfield [2002] derive a relationship between $\left[\mathrm{CO}_{3}{ }^{2-}\right]$ of seawater to the shell mass of Orbulina universa (a planktonic foraminifera) picked from sediment. Assuming the growth time for the organism remains relatively constant, the shell mass is directly analogous to calcification rate. Bijma et al., [2002] suggest a linear relationship between shell mass and $\left[\mathrm{CO}_{3}{ }^{2-}\right](\mathrm{SW}=29.5+$ $0.051\left[\mathrm{CO}_{3}{ }^{2-}\right]$ ), which can be expressed as a function that relates the change in relative growth rate $(\Delta \mathrm{R})$ to the change saturation state $\left(\% \Delta \mathrm{R}=2.0 \Delta \Omega_{\text {calcite, }}\right.$ assuming constant $\left[\mathrm{Ca}^{2+}\right]=10$ mmoles $\mathrm{kg}^{-1}$, current $\Omega_{\text {calcite }}=4.8, \mathrm{pK}_{\mathrm{sp}}=5.62$, current core-top shell mass of $38 \mu \mathrm{g}$ ). This suggests that the calcification rate of $O$. univers $a$ would increase around $12 \%$ for a future ocean with $\Omega_{\text {calcite }}=7$. This approach yields various sensitives from experimental studies on a range of organisms (increases from 12 to 79\%) [Aldridge et al., 2012; Beer et al., 2010; Marshall et al., 2013]. Due to other environmental factors influencing shell mass during growth, there is weak significance in most of the shell mass- $\left[\mathrm{CO}_{3}{ }^{2-}\right]$ experimental relationships. As such, this approach only provides a limited constraint on the impact of elevated alkalinity on calcification rate. However, assuming the proportional change is representative of the proportional change in growth rate, the range of values are substantially less than what would be expected from exclusively abiotic controlled kinetics $\left(\sim 138 \%\right.$ rate change over the same increase in $\Omega_{\text {calcite, }}$, see below). However, if this change was directly translated into elevated PIC export (with no impact on carbon returned to the surface through upwelling) then a future increase of ocean alkalinity [e.g., Ferrer-González and Ilyina 2016] would result in a net flux of $\sim 0.5-4$ Gt C out of the surface ocean. 
Given the relatively low specific gravity of organic molecules (often $<1$ ), their aggregation with inorganic carbon is the mechanism by which they sink out of the surface ocean (often referred to as 'ballasting', [Alldredge and Silver 1988; Klaas and Archer 2002]). The 'marine snow' product has a defined PIC: particulate organic carbon (POC) ratio (the ratio between particulate inorganic and organic carbon, typically 1:4). As such, increased export of inorganic carbon due to increased biological calcification, may also result in increased organic carbon export. Providing the ratio of POC to PIC is $>1$, the organic carbon export would offset the $\mathrm{CO}_{2}$ emission associated with the counter carbonate pump. However, increased biological carbon export (and subsequent remineralization) could decrease the dissolved oxygen content in the water column (see section 7), or result in increased weathering in underlying sediments [Barker et al., 2006].

Considerably more research is required to investigate the response of organisms and ecosystems to elevated alkalinity. An experimental regime for this has been included below in Table 2, which suggests various parameters in the carbonate system for a range of addition scenarios. Scenario A represents the average conditions in the surface ocean following extensive and long term increases in ocean alkalinity as predicted by Ilyina et al., [2013] and this study (section 3.1). Scenario B represents an increase of ocean alkalinity with minimal mitigation of the most extensive $\mathrm{CO}_{2}$ emission scenario [Keller et al., 2014]. Scenario $\mathrm{C}$ represents Scenario A followed by additional $\mathrm{CO}_{2}$ removal from the atmosphere. Scenarios D and $\mathrm{E}$ represent a continuum between Scenario A and the regional 'hot spots' predicted in Ilyina et al., 2013. Scenario F simulates similar $\Omega_{\text {calcite }}$ conditions to E with non-equilibrated $\mathrm{pCO}_{2}$.

Table 2. Experimental range for testing ocean alkalinity carbon storage.

\begin{tabular}{|c|c|c|c|c|c|}
\hline Scenario & Description & $\begin{array}{l}\mathrm{pCO}_{2} \\
(\mu \mathrm{atm})\end{array}$ & $\begin{array}{l}\mathrm{AT}_{\mathrm{T}} \\
\left.(\mathrm{mEq} \mathrm{kg})^{-1}\right)\end{array}$ & $\mathbf{\Omega}_{\text {calcite }^{\mathrm{a}}}$ & $\begin{array}{l}\text { pH } \\
\mathbf{a}\end{array}$ \\
\hline $\mathrm{A}$ & $\begin{array}{l}\text { Extensive alkalinity addition and a limit to } \\
\text { global emissions, global impact }\end{array}$ & 600 & 3.0 & 5.3 & 8.0 \\
\hline B & $\begin{array}{l}\text { Extensive alkalinity addition and unabated } \\
\text { global emissions, global impact }\end{array}$ & 1000 & 3.0 & 3.6 & 7.8 \\
\hline $\mathrm{C}$ & $\begin{array}{l}\text { Extensive alkalinity addition and carbon } \\
\text { dioxide removal from the atmosphere, } \\
\text { global impact }\end{array}$ & 400 & 3.0 & 7.0 & 8.1 \\
\hline $\mathrm{D}$ & $\begin{array}{l}\text { Rapid alkalinity addition, moderate } \\
\text { localized impact }\end{array}$ & 350 & 4.1 & 12.7 & 8.3 \\
\hline $\mathrm{E}$ & $\begin{array}{l}\text { Rapid alkalinity addition, severe localized } \\
\text { impact }\end{array}$ & 350 & 5.5 & 20.1 & 8.4 \\
\hline $\mathrm{F}$ & $\begin{array}{l}\text { Rapid alkalinity addition, severe localized } \\
\text { impact on confined environments }\end{array}$ & 20 & 2.7 & 18.2 & 9.0 \\
\hline
\end{tabular}

aParameters determined using CO2sys [Lewis et al., 1998] using equilibrium constants from Roy et al., [1993] and approximated. Note, $\mathrm{pCO}_{2}$ and $\mathrm{A}_{\mathrm{T}}$ are the independent variables.

\subsection{Abiotic Carbonate Precipitation}

A long standing discussion since the 1960's [Broecker and Takahashi 1966; Cloud Jr., 1962] is whether calcium carbonate can precipitate abiologically from seawater at typical environmental conditions. Early work attempted to explain the formation of 'whitings' [Broecker et al., 2001; Morse et al., 2003], which are characterized by the rapid flocculation 
and deposition of calcium carbonate crystals (a common feature at the Great Bahama Bank and in the Persian Gulf). Initially, spontaneous (pseudo-homogenous) nucleation of carbonate in seawater was postulated to be the cause. But initial studies by Pytkowicz [1965] suggest that highly elevated saturation states were required to spontaneously precipitate calcium carbonate from seawater, confirmed to be between $\Omega_{\text {calcite }} \approx 19$ and 25 by Morse and He [1993]. Others suggest that carbonate precipitation on re-suspended sediment to be the cause of the whiting events [Bustos-Serrano et al., 2009; Morse et al., 2003]. If precipitation occurs on re-suspended sediment, the availability of a carbonate surface area for nucleation is an important control for carbonate precipitation from seawater.

There have been extensive laboratory studies investigating carbonate precipitation in seawater for 'seeded' experiments (i.e. there is nuclei mineral surface in contact with the solution, Figure 12), in which the rate is proportional to the saturation state through equation 24 [see Inskeep and Bloom 1985].

$$
R=k(\Omega-1)^{n} \quad \text { equation } 24
$$

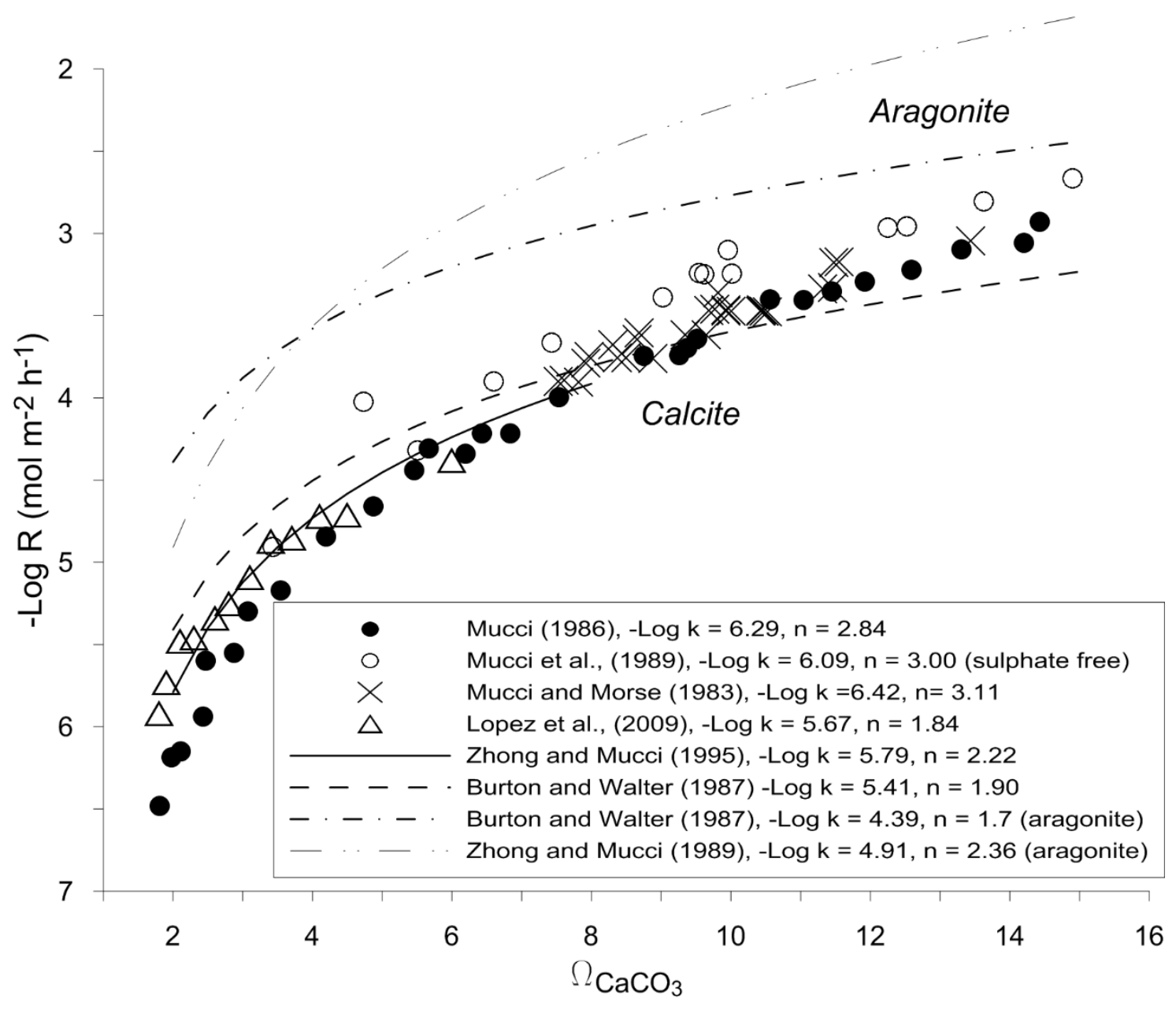

Figure 12: The relationship between saturation state and precipitation rate in natural and synthetic phosphate free seawater at $25^{\circ} \mathrm{C}$. [Burton and Walter 1987; Lopez et al., 2009; Mucci 1986; Mucci et al., 1989; Mucci and Morse 1983; Zhong and Mucci 1995, 1989]

Temperature is thought to control the mineralogy of the precipitating phase. In seawater, calcite nucleates at temperatures $<8^{\circ} \mathrm{C}$, and above this aragonite is the precipitating phase [Morse et 
al., 1997]. Although, the hydrated calcium carbonate polymorph ikaite $\left(\mathrm{CaCO}_{3}, 6 \mathrm{H}_{2} \mathrm{O}\right)$ has been found to be stable at near zero temperatures [Lu et al., 2012].

The role of magnesium [Berner 1975], phosphate [Burton and Walter 1990] and sulfate [Busenberg and Plummer 1985] ions on the inhibition of carbonate precipitation has received substantial attention. Increasing the concentration of magnesium relative to calcium is thought to increase the stoichiometric solubility constant of calcite resulting in a decrease in the $\left[\mathrm{Ca}^{2+}\right]$ $\left[\mathrm{CO}_{3}{ }^{2-}\right]$ ion activity product (IAP, equation 25; adapted from Mucci and Morse [1983])

$$
I A P=\frac{K_{c}^{0}}{K_{c}^{*}} \cdot\left(1-\frac{S}{1000}\right)^{2} \quad \text { equation } 25
$$

Where $\mathrm{K}_{\mathrm{c}}{ }^{0}$ is the thermodynamic solubility of calcite at $25^{\circ} \mathrm{C}$ and $1 \mathrm{~atm}\left(\mathrm{pK}_{\mathrm{c}}{ }^{0}=8.48\right)$ and $\mathrm{S}$ is the salinity. pKc* is thought to vary between 6.59 and 6.27 for $\left[\mathrm{Mg}^{2+}\right] /\left[\mathrm{Ca}^{2+}\right]$ between 0 and 20. Therefore, a magnesium to calcium concentration ratio of 5.1 (typical of the surface ocean) would reduce the ion activity product by $45 \%$ compared to a magnesium free solution. Although the mechanisms for $\mathrm{Mg}^{2+}$ incorporation onto calcite surfaces and its role in the inhibition of precipitation is the subject of continued debate [Astilleros et al., 2010; Davis et al., 2000; Lin and Singer 2009; Morse et al., 2007]. This inhibition is not apparent for aragonite, in which there is an order of magnitude less $\mathrm{Mg}^{2+}$ adsorption onto the precipitating surface [Berner 1975; Mucci and Morse 1983]. However, given the elevated saturation state of aragonite in seawater (Table S1 in the supporting information [Ball and Nordstrom 1991; Parkhurst et al., 1980; Parkhurst and Appelo 1999; Pilson 1998; U.S. Environmental Protection Agency 1998]), some form of inhibition must be occurring.

The presence of phosphate ions $\left(\mathrm{PO}_{4}{ }^{3-}\right)$ in seawater has been shown to inhibit calcite precipitation [Burton and Walter 1990; Mucci 1986] through adsorption onto the calcite surface (equation 26). Both studies investigated elevated initial phosphate concentrations (up to 100's of $\mu$ moles of $\left.\mathrm{P} \mathrm{kg}^{-1}\right)$ with respect to typical surface ocean concentrations $\left(<1 \mu\right.$ mole $\left.\mathrm{kg}^{-1}\right)$.

$$
\log R=-15.76-1.45 \log \left[\mathrm{PO}_{4}^{3-}\right]+3.17 \log (\Omega-1) \quad \text { equation } 26
$$

where $\left[\mathrm{PO}_{4}{ }^{3-}\right]$ is the phosphate concentration in solution (moles $\mathrm{l}^{-1}$ ), and $\mathrm{R}$ is the precipitation rate (moles $\left.\mathrm{m}^{-2} \mathrm{hr}^{-1}\right)$. This relationship is thought to be valid between phosphate concentrations of 1 and $100 \mu$ moles $\mathrm{kg}^{-1}$. Similar to phosphate, the presence of sulfate ions $\left(\mathrm{SO}_{4}{ }^{2-}\right)$ in solution has been shown to inhibit the precipitation of calcite [Bots et al., 2011; Busenberg and Plummer 1985; Fernández-Díaz et al., 2010; Tang et al., 2012]. $\mathrm{SO}_{4}{ }^{2-}$ is present at concentrations of approximately 28 mmoles $\mathrm{kg}^{-1}$ in seawater, but substantially smaller concentrations are sufficient to impede carbonate formation [Busenberg and Plummer 1985].

The availability of carbonate mineral surface area in the ocean is therefore critical in upscaling the laboratory derived precipitation rates. This surface area is notionally provided by resuspended sediment in whiting events on continental shelves [Morse et al., 2003]. The availability of carbonate mineral surface area in the open ocean less well constrained. Using satellite derived Moderate-Resolution Imaging Spectroradiometer data, Balch et al., [2005] present surface particulate inorganic carbon concentrations for a number of oceanic regions. The concentration is larger in coastal areas (2.5-3.7 $\left.\mu \mathrm{g} \mathrm{C}^{-1}\right)$ compared to the open ocean $(0.7$ $-2.8 \mu \mathrm{g} \mathrm{C}^{-1}$ ). Assuming the composition of the PIC is aragonite or Mg-calcite (molecular mass between 97 and $100 \mathrm{~g}$ (carbonate) $\mathrm{mol}^{-1}$, and assuming up to $20 \% \mathrm{MgCO}_{3}$ ), the concentration of carbonate minerals in the open surface ocean may be between 5.6 and $23.4 \mu \mathrm{g}$ 
$1^{-1}$. Walter and Morse [1985] determined the surface area of shallow seawater sediments to be between 0.1 and $24.0 \mathrm{~m}^{2} \mathrm{~g}^{-1}$, although samples were limited to size fraction $>37 \mu \mathrm{m}$, which would exclude smaller particles with a larger surface area to mass ratio. However, based on these measurements, the volumetric surface area of carbonate minerals in the mixed layer could be between $10^{-6.3}$ and $10^{-3.2} \mathrm{~m}^{2} \mathrm{l}^{-1}$. Furthermore, the majority, if not all of the PIC in the surface ocean is produced biologically, which has been shown to considerably less reactive than synthetic counterparts (see the supporting information [Cubillas et al., 2005; Hassenkam et al., 2011; Honjo and Erez 1978; Keir 1980; Walter and Hanor 1979]), possibly due to a protective organic layer on the mineral surface [Godoi et al., 2009]. Figure 12 suggests that a precipitation rate of around $10^{-5}$ moles $\mathrm{m}^{-2} \mathrm{~h}^{-1}$ would be expected for seawater $\left(\Omega_{\text {calcite }}=3-4\right)$ seeded with carbonate minerals. This could equate to a carbonate formation rate of between 0.01 and 14.3 Gt C $\mathrm{y}^{-1}$ in the surface ocean $\left(\sim 300 \times 10^{6} \mathrm{~km}^{2}, 60 \mathrm{~m}\right.$ deep $)$ for a volumetric surface area between $10^{-6.3}$ and $10^{-3.2} \mathrm{~m}^{2} \mathrm{l}^{-1}$. Clearly, the larger value is inconsistent with measurements of carbonate production in the ocean carbon cycle $\left(2 \mathrm{Gt} \mathrm{C} \mathrm{y}^{-1}\right)$. However, it is possible that a lower abiotic precipitation rate is presently masked by a larger biological signal. While biological carbonate precipitation depends on numerous factors, the abiotic precipitation follows a predicable relationship with $\Omega$, and (assuming the lower end member) would increase from 0.01 to $0.4 \mathrm{Gt}$ $\mathrm{C}^{-1}$ for an increase in $\Omega_{\text {calcite }}$ from its current value to 10 (a $20 \%$ increase of carbonate production). This value is speculative, but highlights the potential significance of abiological carbonate precipitation in the ocean at elevated alkalinity.

Spontaneous ('unseeded') nucleation of carbonate minerals is thought to contribute little to carbonate production and export from the surface ocean [Pytkowicz 1965]. Morse and He [1993] suggest that a calcite saturation state of $>19$ is required for nucleation in seawater at $25^{\circ}$ C. In extended duration experiments Pokrovsky [1998] investigated the induction time required for spontaneous $\mathrm{CaCO}_{3}$ (aragonite) nucleation, which is proportional to the saturation state (equation 27)

$$
\log \tau=A+n \log \Omega \quad \text { equation } 27
$$

Where $\mathrm{A}$ is 7.207 and $\mathrm{n}$ is -3.784 for $\left[\mathrm{Mg}^{2+}\right] /\left[\mathrm{Ca}^{2+}\right]$ ratio of 5.3 at $20^{\circ} \mathrm{C}$ (Figure 13). Rather than a threshold saturation state to induce carbonate precipitation, Pokrovsky [1998] suggests an induction time of around 2 months for $\Omega_{\text {aragonite }} \approx 4$ decreasing to around 1 week for $\Omega_{\text {aragonite }}$ $\approx 7$, and 9 hours for $\Omega_{\text {aragonite }}=15$. Similar to seeded precipitation, it is possible that spontaneous nucleation occurs in the surface ocean, but is masked by a larger biological signal, and an increase in carbonate saturation state may accelerate these processes to have a significant impact on the overall carbon cycle. 


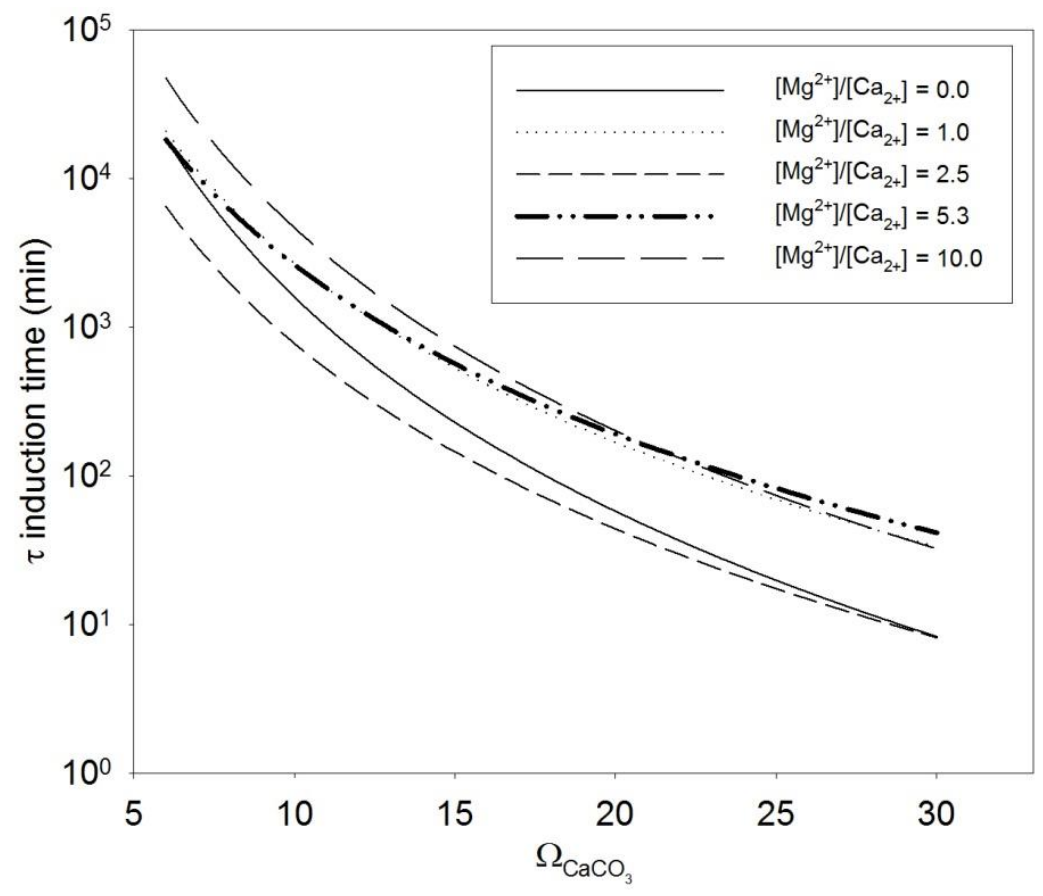

Figure 13: The relationship between homogenous nucleation induction time and carbonate saturation at $20^{\circ} \mathrm{C}$ [adapted from Pokrovsky 1998].

\section{Production processes}

\subsection{Ocean Liming}

Kheshgi $[1995]$ first proposed adding lime $(\mathrm{CaO})$ or portlandite $\left(\mathrm{Ca}(\mathrm{OH})_{2}\right)$ to the surface ocean. Three schemes were explored including (1) the calcination of limestone, (2) the calcination of limestone with flue gas $\mathrm{CO}_{2}$ capture and sequestration, (3) the calcination of limestone with flue gas $\mathrm{CO}_{2}$ capture and sequestration using oxy-fuel firing (a simplification of the latter is included in Figure 14). Accounting for carbon and energy balances across the whole life cycle, the technoeconomics of this approach was assessed by Renforth et al., [2013], for calcite and dolomite feedstocks. They suggested that lime or dolime production in an oxy-fuel fired kiln with CCS, together with the associated energy costs of raw material preparation and ocean disposal, would require between 6 and 10 GJ per net ton of $\mathrm{CO}_{2}$ sequestered. Note that in engineering calculations it is important to consider the total mass processed, which is why units in this section are in terms of $\mathrm{CO}_{2}$ rather than C. Renforth et al., [2013] also explored the use of steam flash calcination and solar calcination, both of which could potentially reduce the costs of lime production (4 and $2 \mathrm{GJ}$ t $\mathrm{CO}_{2}$ respectively). 


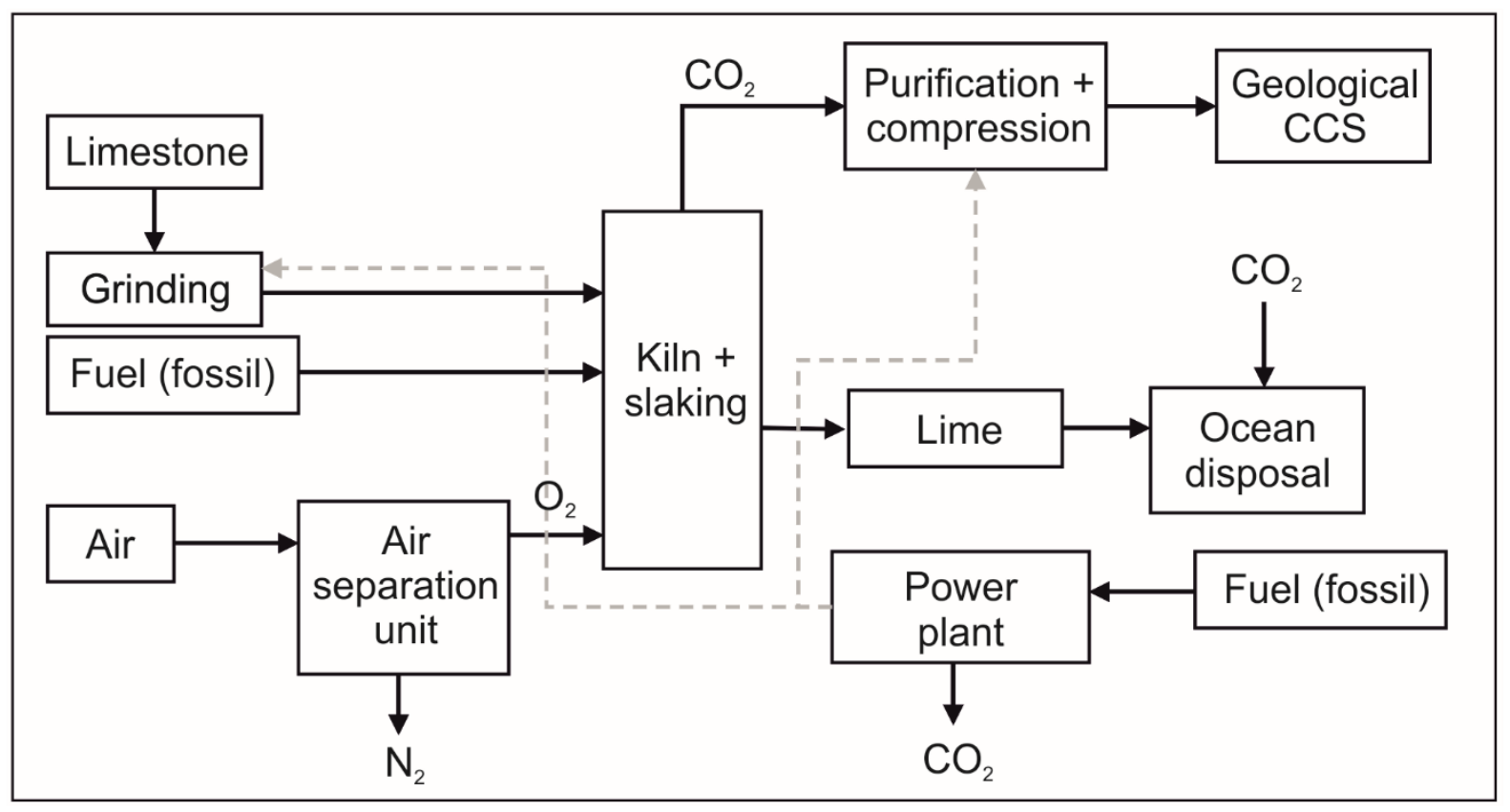

Figure 14: Schematic of lime production for ocean disposal. Developed from Kheshgi [1995] and Renforth et al., [2013].

Renforth and Kruger [2013] investigated the possibility of using forsterite rich olivine $\left(\mathrm{Mg}_{2} \mathrm{SiO}_{4}\right)$ as a feedstock for a coupled mineral carbonation ocean liming process (Figure 15). Ground olivine could be fed into a (single-stage) mineral carbonation reactor (at elevated $\mathrm{pCO}_{2}$ ). This produces magnesite and silica (equation 28). After dewatering, the precipitated magnesite could be fed into a kiln/ slaking system to produce brucite $\left(\mathrm{Mg}(\mathrm{OH})_{2}\right)$ (equation 29), which could be used for ocean liming (equation 30). The evolved $\mathrm{CO}_{2}$ is recycled back into the mineral carbonation reactor. The value of this approach is that it avoids the $\mathrm{CO}_{2}$ burden of decomposing a carbonate raw material, and $\mathrm{MgCO}_{3}$ decarbonates at a lower temperature than $\mathrm{CaCO}_{3}$. However, due to the energy penalty from water evaporation in the kiln, and the additional energy required to grind the olivine, the energy savings over $\mathrm{CaCO}_{3}$ calcination appear to be minimal.

$$
\begin{array}{cr}
\mathrm{Mg}_{2} \mathrm{SiO}_{4}+2 \mathrm{CO}_{2} \rightarrow 2 \mathrm{MgCO}_{3}+\mathrm{SiO}_{2} \text { (Mineral Carbonation) } & \text { equation } 28 \\
2 \mathrm{MgCO}_{3}+2 \mathrm{H}_{2} \mathrm{O} \rightarrow 2 \mathrm{Mg}(\mathrm{OH})_{2}+2 \mathrm{CO}_{2} \text { (Calcination) } & \text { equation } 29 \\
2 \mathrm{Mg}(\mathrm{OH})_{2}+4 \mathrm{CO}_{2} \rightarrow 2 \mathrm{Mg}^{2+}+4 \mathrm{HCO}_{3}^{-} \text {(Ocean liming) } & \text { equation } 30
\end{array}
$$




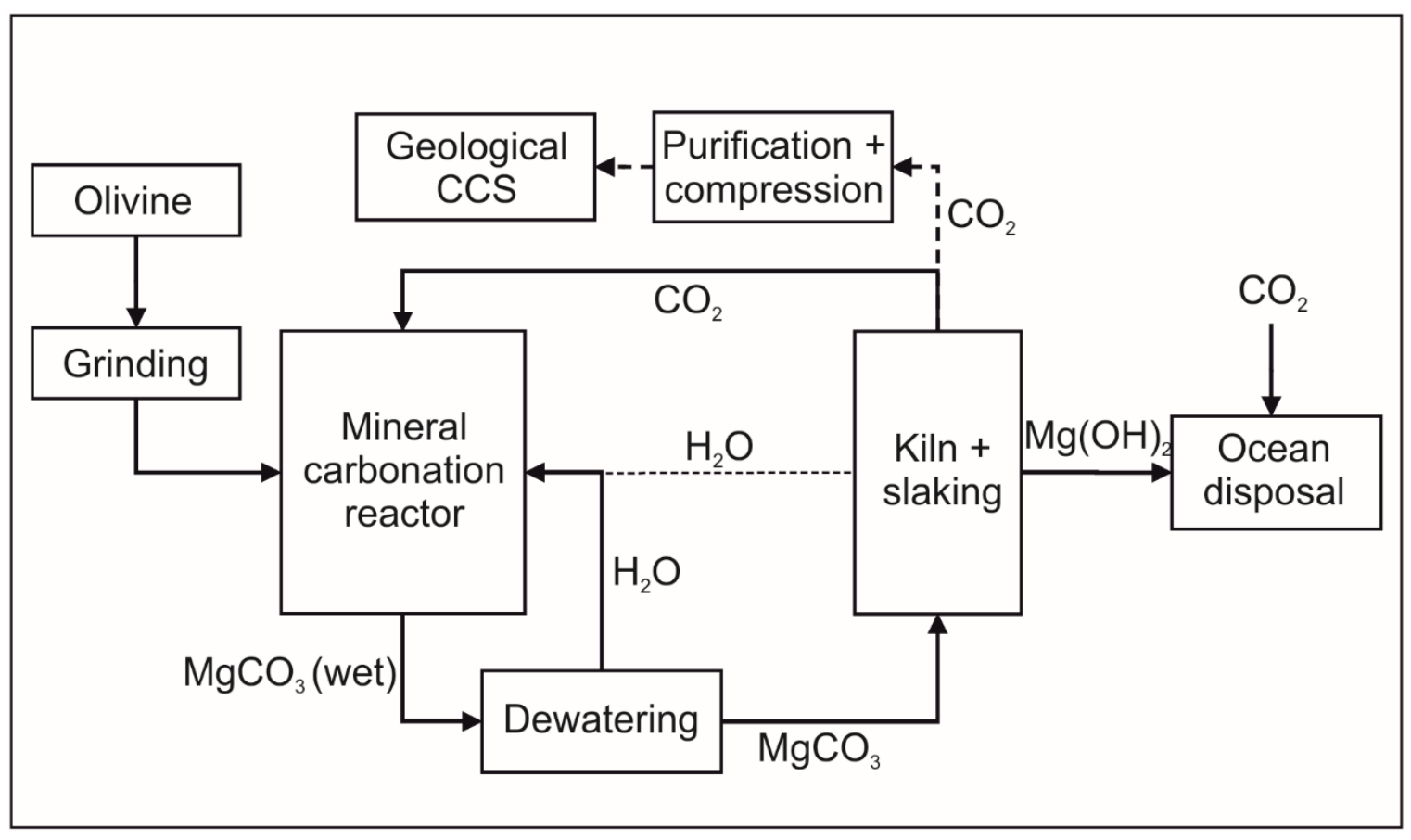

Figure 15: A simplified schematic of a coupled mineral carbonation ocean liming process. Adapted from Renforth and Kruger [2013].

A number of multi-step mineral carbonation processes promote the creation of $\operatorname{Mg}(\mathrm{OH})_{2}$ as part of the overall reaction to capture carbon dioxide from point sources as $\mathrm{MgCO}_{3}[$ Fagerlund et al., 2012; Madeddu et al., 2014; Nduagu et al., 2012]. The use of the produced $\mathrm{Mg}(\mathrm{OH})_{2}$ to increase ocean alkalinity has not been explored. However, such a scheme reduces the constraints on plant location (rather than being next to the emission point source it could be located to exploit unused renewable energy), and notionally reduces the overall cost by $\sim 60-$ $80 \%$ (from additional $\mathrm{CO}_{2}$ draw-down per mole of base added). However, it is likely that the $\mathrm{Mg}(\mathrm{OH})_{2}$ will need to be relatively pure for ocean liming to minimize biological impact from $\mathrm{Fe}$ and Si that may be present.

\subsection{Accelerated Weathering of Limestone}

The accelerated weathering of limestone is the process in which flue gasses are scrubbed with a mixture of limestone and seawater [Rau and Caldeira 1999; Figure 16]. It is directly analogous to flue gas desulfurization, albeit on a larger scale. Seawater brought into equilibrium with $15 \% \mathrm{CO}_{2}$ and calcite will be able to sequester $0.53 \mathrm{t} \mathrm{CO}_{2}$ per kt of seawater [Caldeira and Rau 2000]. Therefore, a coal fired power station producing $500 \mathrm{MW}$ and $0.5 \mathrm{t}$ $\mathrm{CO}_{2} \mathrm{~s}^{-1}$ will require around $900 \mathrm{~m}^{3} \mathrm{~s}^{-1}$ of seawater, which is, for example, two orders of magnitude greater than the largest seawater reverse osmosis facilities $\left(1-5 \mathrm{~m}^{3} \mathrm{~s}^{-1}\right.$ [Lior 2012]), and an order of magnitude greater than the largest sewage treatment works (e.g., the Atotonilco el Alto treatment plant, $35 \mathrm{~m}^{3} \mathrm{~s}^{-1}$ [Mendoza 2012]). However, a once-through seawater cooled, $500 \mathrm{MW}$ plant pumps some $20 \mathrm{~m}^{3} \mathrm{~s}^{-1}$ of seawater, meaning that around $6 \%$ of the plant's $\mathrm{CO}_{2}$ could theoretically be converted to seawater alkalinity without new pumping. The volume ratio between liquid and gas in the reactor has a strong influence on capture efficiency, too little water in the reactor and there is insufficient carbonate solubility to remove $\mathrm{CO}_{2}$ from the gas phase. Increasing the liquid-gas ratio increases the capture efficiency until a maximum is reached, after which the efficiency starts to decrease as $\mathrm{CO}_{2}$ in the gas is used to suppress the 
natural buffering of seawater rather than promoting carbonate dissolution. While most of this research has focused on flue gas capture, AWL could be relevant to air capture if applied to mitigation of $\mathrm{CO}_{2}$ from electricity production via biomass combustion (i.e. an alternative storage mechanism for biomass energy carbon capture and storage).

Figure 16: Schematic for the accelerated weathering of limestone.

Langer et al., [2009] suggest that 71\% of US power stations are located within $100 \mathrm{~km}$ of limestone deposits, and 200 are adjacent to the coast. Given the water requirements, the AWL reactor must be located adjacent to the coast. While there is considerable potential for AWL, (Rau et al, [2007] suggests a minimum cost of $<\$ 10$ per $\mathrm{t} \mathrm{CO}_{2}$ via use of waste limestone and recycled once-through power plant cooling seawater), the engineering requirements require considerable more research.

\subsection{Electrochemical splitting}

To overcome the $\mathrm{CO}_{2}$ geological sequestration burden of ocean liming, House et al., [2007] proposed a method to increase aqueous $\mathrm{NaOH}$ through direct electrolysis of seawater (Figure 17). This chlor-alkali method has been used industrially for over 100 years to produce $\mathrm{NaOH}$ from seawater and brines [Brinkmann et al., 2014]. The electrolysis cell consists of an anode and cathode separated by a sodium permeable membrane. Seawater (or an enriched $\mathrm{NaCl}$ brine) is fed into the section of cell containing the anode, chloride ions are oxidized into chlorine gas. At the cathode, hydrogen ions are reduced from a stream of fresh water to produce hydrogen gas. The result is a movement of $\mathrm{Na}^{+}$ions across the membrane and the creation of aqueous $\mathrm{NaOH}$ at the cathode. This high $\mathrm{pH}$ solution could then be added to the ocean to increase alkalinity. The chlorine and hydrogen gases could be reacted in a fuel cell to produce hydrochloric acid, which must be neutralized through reaction with a silicate mineral. Assuming no efficiency losses, the energy requirements of electrolysis (1.8 GJ per $\left.\mathrm{t} \mathrm{CO}_{2}\right)$ is completely met by the exergy ('available' energy) destruction in the fuel cell and during acid neutralization (1.9 GJ per $\mathrm{t} \mathrm{CO}_{2}$ ). However applying a range of efficiency scenarios and energy emission intensities, House et al., [2007] suggest that an optimistic scenario (70\% efficiency for electrolysis and fuel cell generation, on a 10 moles $\mathrm{kg}^{-1} \mathrm{NaCl}$ solution) would require between 3 and $18 \mathrm{GJ}$ per $\mathrm{tCO}_{2}$. More pessimistic efficiencies are unlikely to be carbon negative when exploiting anything but a decarbonized energy sector. 


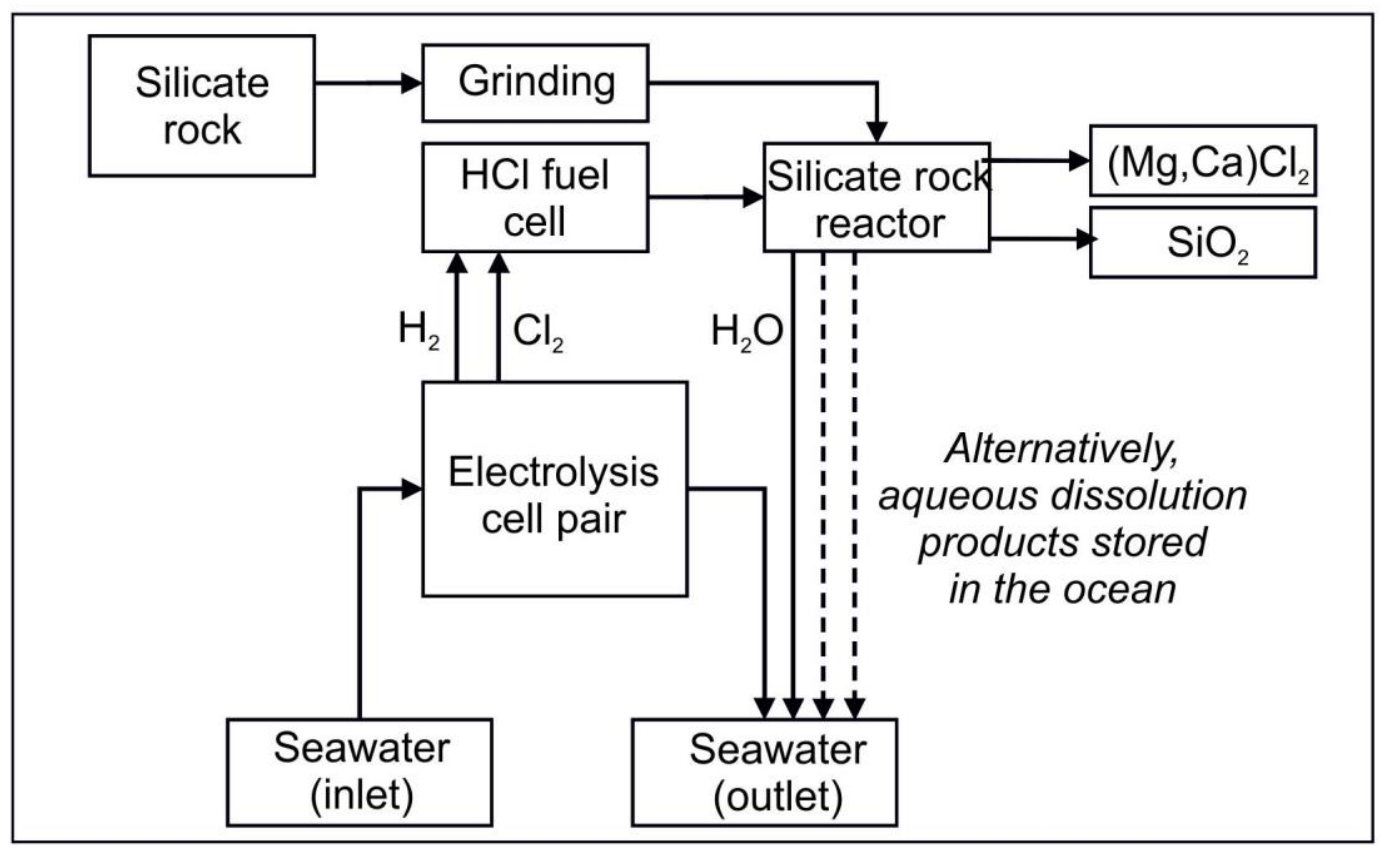

Figure 17: Direct electrolysis of seawater (adapted from House et al., [2007])

Rau [2008] proposed an alternative method that uses a $\mathrm{CaCO}_{3}$ solution as the electrolyte (Figure 18), in which acid conditions produced around the anode dissolve $\mathrm{CaCO}_{3}$. In such a solution the $\mathrm{CO}_{3}{ }^{2-}$ ions would migrate towards the anode, protonate, and degas as $\mathrm{CO}_{2}$. The $\mathrm{Ca}^{2+}$ cations would migrate towards the cathode to produce a high $\mathrm{pH} \mathrm{Ca}(\mathrm{OH})_{2}$ rich solution. Notionally, $\mathrm{Ca}(\mathrm{OH})_{2}$ could precipitate at sufficiently elevated $\mathrm{pH}$ and $\left[\mathrm{Ca}^{2+}\right]$, however Rau [2008] suggests the addition of the high $\mathrm{pH}$ solution to the ocean as the mechanism for ocean alkalinity increase. The energy requirements for this may be around $5 \mathrm{GJ}$ (electrical) per $\mathrm{t} \mathrm{CO}_{2}$ consumed, which to be $\mathrm{CO}_{2}$-emissions-negative must be powered by non-fossil-derived electricity. A similar energy expenditure $\left(7.6 \mathrm{GJ}_{\mathrm{e}}\right.$ per $\left.\mathrm{t} \mathrm{CO}_{2}\right)$ was calculated if silicate minerals rather than carbonates were dissolved at the anode in seawater [Rau et al., 2013].

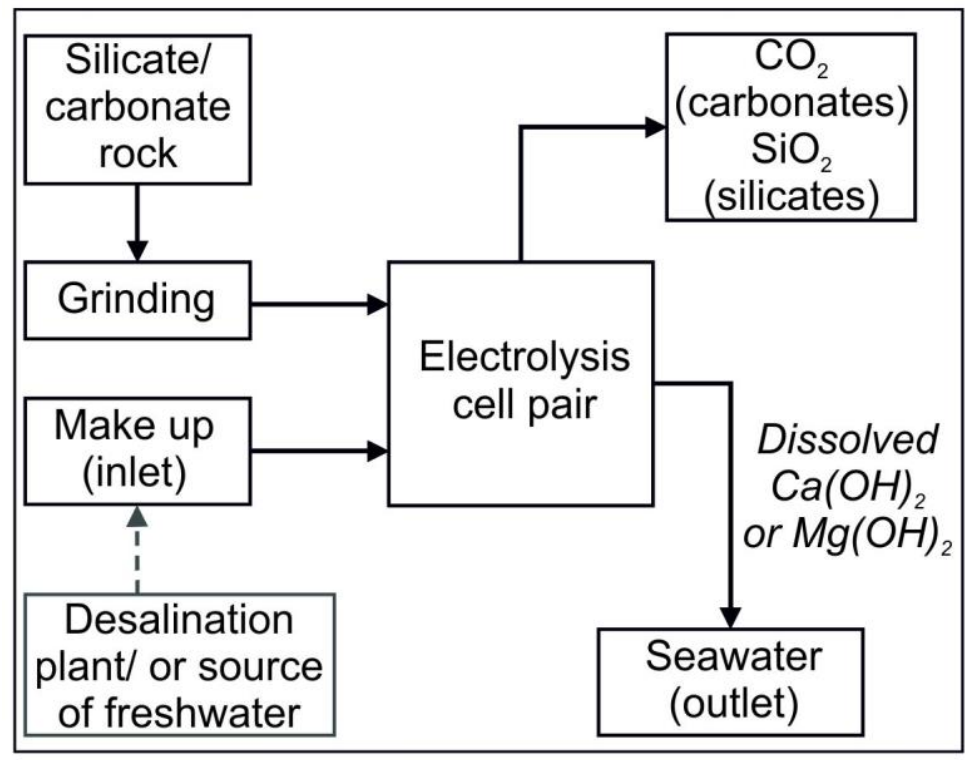

Figure 18: Electrochemical accelerated dissolution of minerals [Rau 2008; Rau et al., 2013].

Seawater, natural or artificial brines could be the source of the electrolyte, which would 
negate the use of freshwater/desalination (although this would require the treatment of $\mathrm{H}_{2}$ and $\mathrm{Cl}_{2}$ produced)

An approach was proposed by Davies [2015], in which an $\mathrm{MgCl}_{2}$ rich brine is thermally decomposed into magnesium oxide and hydrochloric acid, which requires around $0.8 \mathrm{GJ}$ of electrical and $13 \mathrm{GJ}$ of thermal energy per $\mathrm{t} \mathrm{CO}_{2}$ sequestered. Like the electrochemical methods discussed above, the hydrochloric acid is disposed/neutralized by reaction with silicate rocks. As Davies [2015] suggests, this proposal is probably most suitable for the treatment of desalination reject brines using solar energy, the global potential of which is on the order of 1 $\mathrm{Mt} \mathrm{CO}_{2} \mathrm{a}^{-1}$.

\subsection{Comparative Cost Estimate}

The limited technoeconomic assessment of these processes largely focus on deriving overall energy and carbon balances, and there has been little optimization. Furthermore, some of the reaction kinetics are poorly constrained (particularly for artificial materials), resulting in considerable uncertainty in the design of the flow sheet. Finally, the energy and cost associated with transporting the material from the extraction site to the processing or application site (see below) can only be estimated at this stage. However, Table 3 brings together the various cost estimates of ocean alkalinity $\mathrm{C}$ sequestration technologies. An important consideration is a 'threshold' imposed by the energy intensity of carbon emissions derived from fossil fuels (i.e. the inverse of the carbon intensity of fuels; italicized in Table 3). Surpassing $10 \mathrm{GJ} \mathrm{t} \mathrm{CO}_{2}$ of thermal energy or $3 \mathrm{GJ} \mathrm{t} \mathrm{CO}_{2}$ of electrical energy, then it may be more reasonable to decommission a coal fired power station than to run the negative emission technology. While the predicted financial and energy costs are variable, and at this stage largely speculative, they suggest a level of competitiveness with 'conventional' methods of mitigation.

Table 3. Comparison of electrical and thermal energy requirements and financial costs of ocean alkalinity carbon storage technologies

\begin{tabular}{llcc}
\hline Technology & \multicolumn{2}{c}{ GJ tCO2 } & US\$ tCO \\
\cline { 2 - 4 } & Electricity & Thermal \\
\hline Ocean Liming (Oxy-fuel flash & 1.3 & 4.8 & 126 \\
$\begin{array}{l}\text { calciner: limestone) } \\
\text { Ocean Liming (Endex CFC: }\end{array}$ & -0.1 & 5.5 & 100 \\
$\begin{array}{l}\text { limestone) } \\
\text { Ocean Liming (Oxy-fuel flash }\end{array}$ & 0.7 & 3.2 & 95 \\
$\begin{array}{l}\text { calciner dolomite) } \\
\text { Ocean Liming (Endex CFC: }\end{array}$ & -0.1 & & \\
dolomite) & & 4.2 & 72 \\
\end{tabular}




\begin{tabular}{|c|c|c|c|}
\hline Ocean Liming (Solar calciner: & 0.4 & $0.6^{\mathrm{b}}$ & 159 \\
\hline \multicolumn{4}{|l|}{ limestone) } \\
\hline Electrochemical weathering (Mg- & $5^{\mathrm{c}}$ & & - \\
\hline \multicolumn{4}{|l|}{ Silicate) } \\
\hline Electrochemical weathering $\left(\mathrm{CaCO}_{3}\right)$ & $5^{\mathrm{c}}$ & & $14-190$ \\
\hline $\begin{array}{l}\text { Electrochemical weathering }(\mathrm{NaOH} \\
\text { production) }\end{array}$ & $3-18$ & & - \\
\hline $\begin{array}{l}\text { Direct carbonate addition to } \\
\text { upwelling regions }\end{array}$ & $<0.1$ & 3.6 & - \\
\hline Mineral Carbonation/Ocean liming & 2.2 & 5.0 & \\
\hline Accelerated weathering of limestone & & & $10-40$ \\
\hline Enhanced weathering & $0.1-8.4$ & $0.8-4.2$ & $20-600$ \\
\hline Direct air capture & $7.5-10$ & & $100-1000$ \\
\hline Typical cost of 'conventional' CCS & 6.7 & & $30-100$ \\
\hline Energy cost of decommissioning coal & 3 & 10 & \\
\hline
\end{tabular}

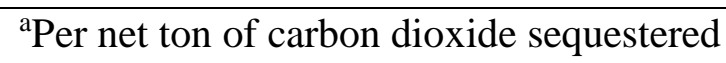

${ }^{\mathrm{b}}$ Additional thermal requirements from fossil fuels

${ }^{c}$ Per ton of $\mathrm{CO}_{2}$ extracted rather than net sequestration.

[Renforth et al., 2013; Renforth and Kruger 2013 and references therein]

\subsection{Upscaling production}

If the proposal is to mitigate humanity's $\mathrm{CO}_{2}$ emissions then a solution must be able to operate on a scale that is meaningful to the challenge. However, defining what is 'meaningful' is problematic, which has previously been attempted by deconstructing the problem rather than assessing what might be possible. For instance, Pacala and Socolow [2004] chose annual emissions 'wedges' of $1 \mathrm{Gt} \mathrm{C} \mathrm{a}^{-1}$ by 2050 (each wedge mitigating around $14 \%$ of their business as usual $\mathrm{CO}_{2}$ emissions scenario) by upscaling known mitigation strategies. Refining this approach to include projected efficiency improvements and the most up to date emission pathways, Davis et al., [2013] used 19 (9 to stabilize emissions and 10 to reduce to zero), although the wedge size remains the same. A consequence of the wedge approach is that it has conceptually defined the scale at which a mitigation technology should be able to achieve. The problem is the choice of $1 \mathrm{GtC}$ is largely arbitrary. It is possible that the portfolio of climate change mitigation technologies will contain considerably more than 7 or 19 different measures (e.g., the UK Government's pathways calculator contains over 40 proposals [DECC 2010], and does not expand upon a range of over 20 geoengineering proposals [Bellamy et al., 2012]). While some measures may be able to operate at a multiple $\mathrm{Gt} \mathrm{C} \mathrm{a}^{-1}$ scale (e.g., renewable energy 
proposals), many of them could well be more feasible at hundreds of $\mathrm{Mt} \mathrm{C} \mathrm{a}^{-1}$ scale (solving 1 $-5 \%$ of the emission mitigation requirements).

Another important aspect of scale is the cumulative potential of a mitigation strategy. Humanity could emit between 880 (RCP 2.6) and thousands of Gt C by the end of the century (section 1). This is particularly important when considering technologies that propose to store $\mathrm{CO}_{2}$ in another part of the Earth system (or in geological reservoirs), where the capacity of the sink may be limited, and the total requirements of storage could be on the order of trillions of $t$ of C. While the efficacy of a potential technology is an important consideration (i.e. the proportional capacity for dealing with the problem), the decision to invest in a technology must also include the predicted future costs, the required resources to progress development, and the lead time for implementation. There is no widely employed or transparent decision making framework for investment in technology development for a climate change solution portfolio.

For a mineral sequestration technology to capture $\mathrm{CO}_{2}$ as bicarbonate in the ocean, the theoretical mass ratio between mineral and $\mathrm{CO}_{2}$ is shown in Table 1 . While some of the anthropogenically produced minerals achieve a mass ratio of $>1 \quad\left(\mathrm{CO}_{2}\right.$ : mineral), their production necessitates the extraction and processing of natural minerals (e.g., the calcination of limestone to produce lime). Therefore, between 1 and 3.5 tons of raw material will need to be extracted for every ton of $\mathrm{CO}_{2}$ captured. This requirement will increase once inefficiencies are accounted for.

The cement industry is a useful analogue for the scale and rate of deployment of a mineral carbon sequestration technology. The global cement industry extracts around 7 billion tons of raw material (mainly limestone, shale and/or clay), which are ground and processed in a kiln, and the finished product ( 4.2 billion tons of cement $\mathrm{a}^{-1}$ ), is distributed locally. In 1960 global cement production was around $0.3 \mathrm{Gt}$, in 2014 it was $4.2 \mathrm{Gt}$. The majority of this production capacity was created in China, which had an annual compound production growth of $11.5 \%$ between 2000 and 2012 [USGS, 2014]. However, it is unclear how comparable this growth is to a future mineral carbon sequestration industry (i.e. are the constraints comparable?). For instance, infrastructure development during the industrial revolution expanded at about 5\%, tractor production in the U.S. during the height of agricultural mechanization grew at a rate of $16 \%$, post-war U.K. road infrastructure grew at a rate of $15 \%$, and recent cement production grew at a rate of 12\% ([DECC 2015; Hilbert and López 2011; Roth and Divall 2015; Renforth et al., 2011; USGS 2014]), see supporting information Table S3). With appropriate policy/market drivers, an expansion of $>20 \%$ may be possible, but $10-15 \%$ may be more realistic, and consistent with historic industrial development.

Figure 19 presents the time required to upscale production to 0.1 (Figure 19A), 1 (Figure 19B) and 10 (Figure 19C) $\mathrm{Gt} \mathrm{a}^{-1}$ for a range of exponential growth rates (equation 31). A growth rate of $12 \%$ would need to be sustained for 45 to 60 years to create $1 \mathrm{Gt}$ worth of production capacity (based on an initial capacity of $1-5 \mathrm{Mt} \mathrm{a}^{-1}$ ). However, sustaining this growth rate for an additional 20 years would create $10 \mathrm{Gt}$ of capacity. Hypothetically, if $50 \mathrm{Mt} \mathrm{a}^{-1}$ of spare capacity was available (and convertible) in existing industries, then the upscaling period would be 26 years for $1 \mathrm{Gt}$ (based on $12 \%$ growth)

$$
P_{t}=P_{0}(1+r)^{t} \quad \text { equation } 31
$$

$\mathrm{P}$ is the production in year $\mathrm{t}$ of the expansion with growth rate $\mathrm{r}$, and $\mathrm{P}_{0}$ is the initial production. 


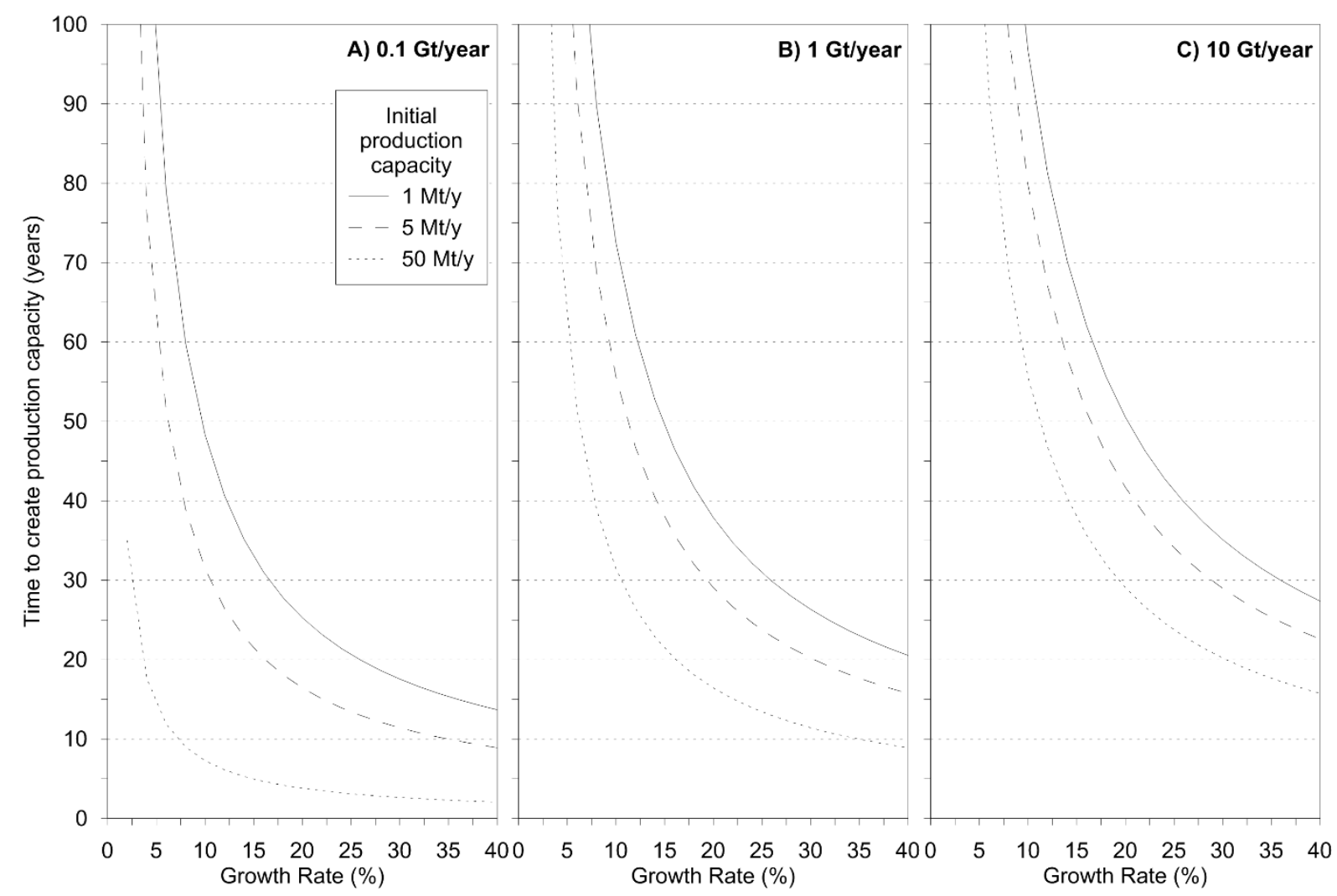

Figure 19: Time required to create A) $0.1 \mathrm{Gt}, \mathrm{B}) 1 \mathrm{Gt}$, and C) $10 \mathrm{Gt}$ worth of production capacity as a function of technology growth rate (assuming an exponential growth). The different lines represent the initial capacity of $1 \mathrm{Mt} \mathrm{a}^{-1}$ and $5 \mathrm{Mt} \mathrm{a}^{-1}$ (which are broadly consistent with the minimum and maximum production capacity of a single cement plant), and $50 \mathrm{Mt} \mathrm{a}^{-1}$ which is (hypothetical/fictional) spare capacity present within existing industries.

\section{$6 \quad$ Ocean Transport and Disposal}

\subsection{Ocean Transport}

Moving material from the extraction and production site to the ocean will require a combination of land and ocean transport. The use of these depends on the location of the mineral resource, the processing plant, port facilities, and the application area of the ocean. As such, at this stage, it is possible to make only general statements regarding transport requirements of a mineral carbon sequestration proposal.

Global shipping capacity is around 8 billion tons $\mathrm{a}^{-1}$ (the utilization of which broadly follows fluctuations in international trade [UNCTAD 2012]). Capacity of material transport over land is likely to be substantially more (10's of billions of tons). For the addition of material to the ocean Harvey [2008] suggests a fleet of 3000 ships would be required to add $4 \mathrm{Gt}$ of $\mathrm{CaCO}_{3}$. Renforth et al., [2013] suggest a fleet of 100 ships would be required to add $1 \mathrm{Gt}$ of $\mathrm{Ca}(\mathrm{OH})_{2}$ (the difference between these studies is largely a result of the solubility different of the materials added). Compared to an existing fleet of 50,000, this represents a small expansion. While upscaling transport and infrastructure to cope with additional movement of material could be challenging, upscaling the extraction and processing components would probably be more limiting. Transport over land incurs substantially more cost (energy and financial) than 
over the ocean (see supporting information Table S4, [CEFIC 2011; Davis et al., 2011]). However, a mineral carbon sequestration technology may have an energy foot print of GJ per ton of material, it may be possible to move material 10s or 100s of $\mathrm{km}$ over land and $1000 \mathrm{~s} \mathrm{~km}$ over the ocean before significantly impacting the energy or carbon balance of the technology. Given the abundance of mineral resource, it may be possible to optimize a technology to minimize transport requirements. Moosdorf et al., [2014] demonstrated that large distances can be covered with minimal impact on the $\mathrm{CO}_{2}$ budget of enhanced weathering proposals.

\subsection{Ocean addition}

Compared to the distributed global impact, the localized impact of increased alkalinity appears to be more substantial. For instance, if alkalinity addition were more rapid than the rate of $\mathrm{CO}_{2}$ gas to liquid transfer, there would be an increase in $\left[\mathrm{CO}_{3}{ }^{2-}\right]$ and $\left[\mathrm{OH}^{-}\right]$and a decrease in $\left[\mathrm{CO}_{2}\right.$ (aq)]. However, these effects would be highly transient in the open ocean. Figure 20 shows that addition rates would have to be several orders of magnitude larger than suggested in Renforth et al., [2013] before a significant and extended impact on $\mathrm{pH}$ was observed (see Box 2 for ocean dispersal discussion). This assumes instantaneous dissolution within the rapidly mixed wake of a ship. It is possible that a particle could sink out of the wake and dissolve in the less turbulent part of the mixed layer, creating areas of elevated alkalinity.
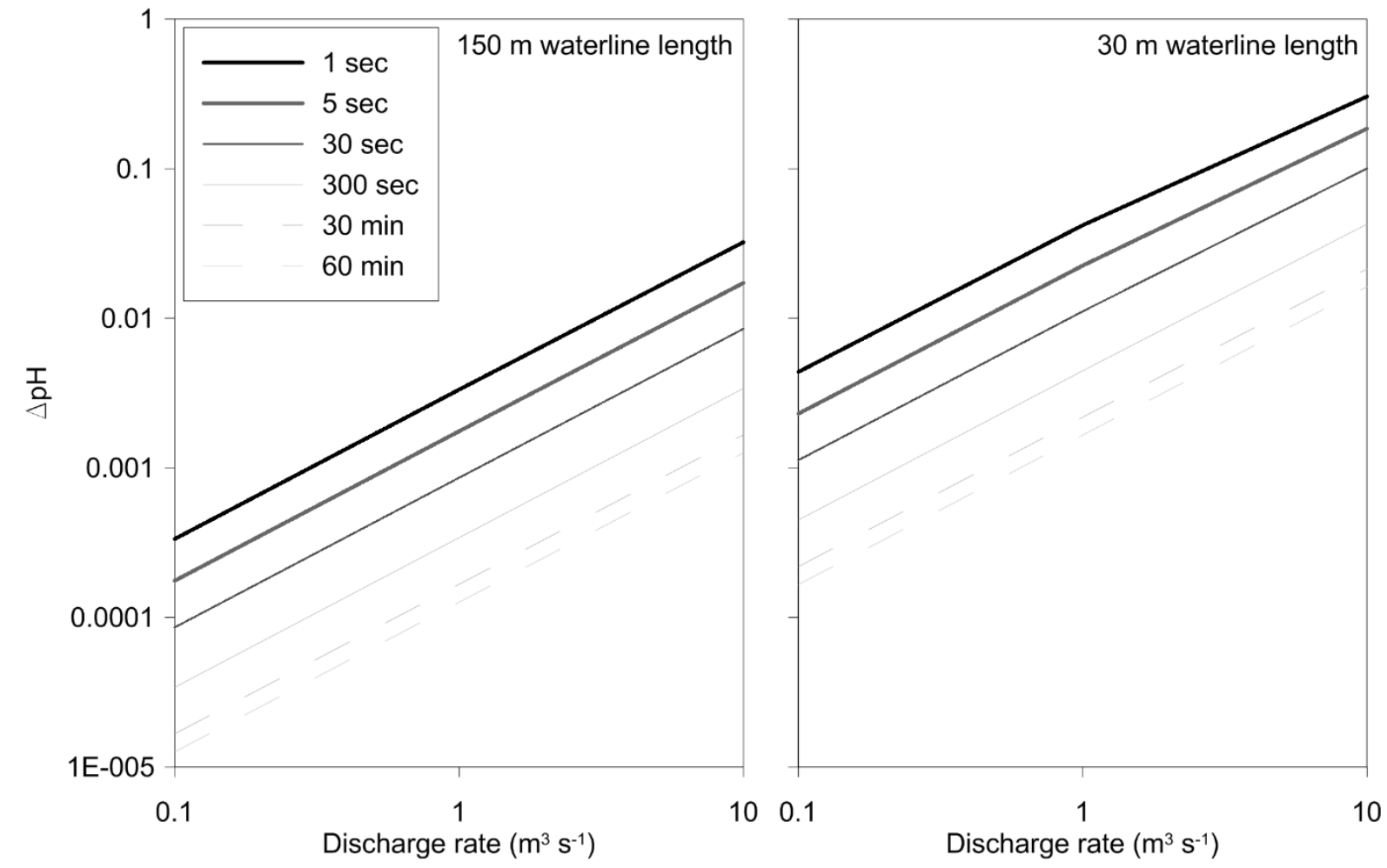

Figure 20: Change in $\mathrm{pH}$ from dumping of high $\mathrm{pH}$ solutions (or instantly dissolved particles) from the rear of a ship moving at 10 knots $\left(18.5 \mathrm{~km} \mathrm{~h}^{-1}\right)$, derived from the IMO formula (see

Box 2). Lines denote time after disposal. The model assumes no $\mathrm{pH}$ buffering.

The cumulative effect of regional alkalinity addition over decades may produce conditions with the potential significant ecosystem impact [e.g., Ilyina et al., 2013]. It is conceivable that in some confined environments, or under rapid application rates, the ambient $\mathrm{pH}$ may be sufficiently elevated to impact ocean biology. Establishing the relationship between addition rate and local impact could be used to develop application limits to minimize environmental 
impact. Furthermore, alkalinity addition will likely create secondary environmental impacts specific to the technology and the application site due to the co-dissolution of elements that could stimulate biological activity.

Box 2: The dynamics of disposal at sea

Dilution rates in the wake of ships has been investigated since the 1960s [Delvigne 1987; Delft 1970), both theoretically [Lewis 1985] and through laboratory and field testing [Byrne et al., 1988]. The general formula (equation 32) for the dilution factor (D) in a ships wake was adopted by the International Maritime Consultative Organization (now the 'International Maritime Organization') in 1975 based on a paper submitted by the Netherlands and Norway [IMCO 1975] and can be formulated as:

$$
D=\frac{c}{Q} \cdot U^{1.4} \cdot L^{1.6} \cdot t^{0.4} \quad \text { equation } 32
$$

Where $\mathrm{c}$ is a constant equivalent to 0.0030 for a single discharge orifice or 0.0045 for two discharge orifices, $\mathrm{Q}$ is the volume discharge rate, $\mathrm{U}$ is the vessel speed, $\mathrm{L}$ is the waterline length, and $\mathrm{t}$ is the time after disposal. However, field testing has shown that this formula underestimates the dispersal rate by 3 to 10 times [Bryne et al., 1988; Chou 1996]. equation 32 assumes that the density difference between the disposed chemical and seawater is minimal, and thus has greater relevance to the disposal of liquid. Although, Balch et al., [2005] demonstrated rapid lateral dispersion of particulate calcium carbonate during an addition experiment to coastal waters.

\section{$7 \quad$ Environmental impact and regulation}

\subsection{Global consequences of alkalinity addition}

The recent accumulation of anthropogenic $\mathrm{CO}_{2}$ in the atmosphere has caused a decrease in surface ocean $\mathrm{pH}$ by 0.1 units [Doney et al., 2009]. Future $\mathrm{CO}_{2}$ emissions will decrease the $\mathrm{pH}$ further. Increasing the $\mathrm{pCO}_{2}$ in equilibrium with the ocean increases $\left[\mathrm{CO}_{2(\mathrm{aq})}\right]$ in solution, and decreases $\left[\mathrm{CO}_{3}{ }^{2-}\right]$. Initial experiments [Riebesell et al., 2000] suggested that a reduction in $\left[\mathrm{CO}_{3}{ }^{2-}\right]$ and therefore a reduction in the saturation state of carbonate minerals, would lead to a reduction in carbonate formation of calcifying organisms. Substantial research has been undertaken in the last 20 years, which has unearthed a complex relationship between ocean chemistry and ecosystem impact [Fabry et al., 2008; Rost et al., 2008]. The consequences for organisms that precipitate extracellular carbonate (e.g., corals) is somewhat starker [HoeghGuldberg et al., 2007]. Broadly, limiting ocean acidification is an important driver for reducing $\mathrm{CO}_{2}$ emissions. Within this context, some have proposed the intentional addition of alkalinity to the oceans as a means to limit harm [Rau et al., 2012; Williamson and Turley 2012].

Almost $50 \%$ of historic anthropogenic $\mathrm{CO}_{2}$ emissions have been absorbed into the ocean [Sabine et al., 2004]. The ability of the oceans to take up additional $\mathrm{CO}_{2}$ is described by the Revelle Factor (RF) (i.e. the proportional change of aqueous $\mathrm{CO}_{2}$ to DIC, equation 33; [Revelle and Suess 1957]). The capacity for $\mathrm{CO}_{2}$ uptake is inversely proportional to $\mathrm{RF}$, and is currently between 9 and 15 [Sabine et al., 2004]. The RF has increased by around $15 \%$ on pre-industrial levels and will increase by $30-50 \%$ for a doubling of $\mathrm{CO}_{2}$ [Hauck and Völker 2015]. Increasing ocean alkalinity will proportionally decrease the RF by around 0.15 to 0.19 (for every \% change in alkalinity there will be a $0.15 \%$ to $0.19 \%$ decrease in RF, Figure 21 ). If alkalinity increased 
in the surface ocean from 2.3 to $3.0 \mathrm{mEq} \mathrm{kg}{ }^{-1}$, the Revelle Factor would decrease by around $5 \%$ (offsetting $10 \%$ of the potential anthropogenic increase).

$$
R F=\left[\frac{\partial\left[\mathrm{CO}_{2(a q)}\right]}{\left[\mathrm{CO}_{2(a q)}\right]} / \frac{\partial C_{T}}{C_{T}}\right]_{A_{T}=\text { const. }} \quad \text { equation } 33
$$

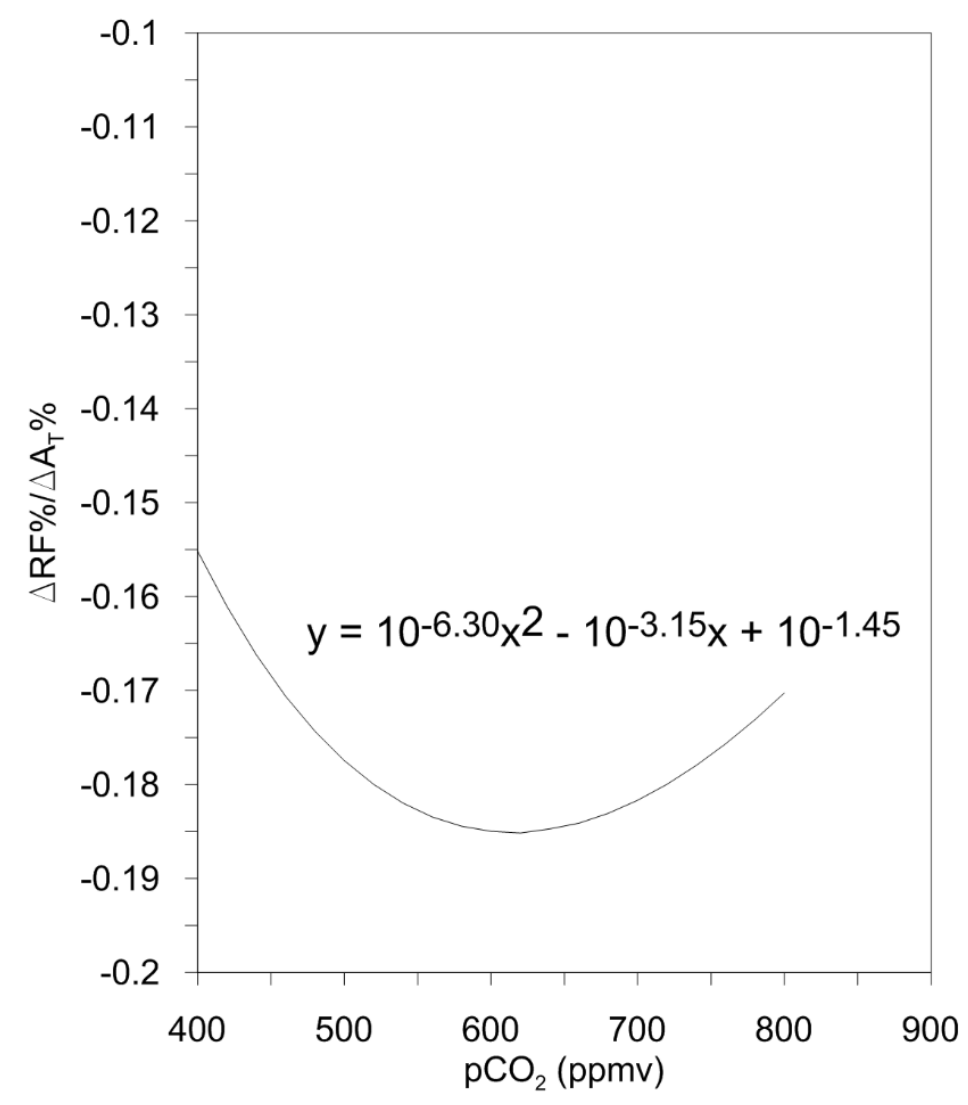

Figure 21: The proportional change in the Revelle Factor to total alkalinity increase.

As suggested by modeling results in section 5, the globally distributed effects of an increase in

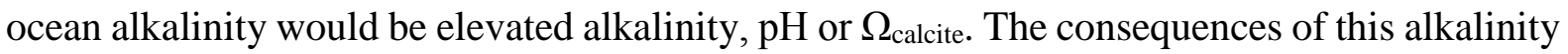
increase on marine ecosystems is poorly understood, but it may provide a competitive advantage for calcifying organisms [Henderson et al., 2008].

The addition of silicate minerals to the ocean could have a substantial fertilization effect from the dissolution of iron and silica in the material [Köhler et al., 2013]. Adding a billion tons of ultrabasic rock to the ocean (for $\sim 0.8$ billions of tons of $\mathrm{CO}_{2}$ removal), will also add $\sim 200$ million of tons of silicon and $\sim 70$ million tons of iron (see Renforth [2012] for a summary of rock chemical constituents). The proportion of Fe or Si dissolved and liberated is likely to be a fraction of the total added in the olivine, although it is difficult to predict [Hauck et al., 2016]. There is considerable literature on the potential environmental impact of ocean fertilization, including increased production of other more potent greenhouse gasses $\left(\mathrm{N}_{2} \mathrm{O}\right.$ and $\mathrm{CH}_{4}$, [Fuhrman and Capone 1991]), lower dissolved oxygen, and nutrient driven ecosystem structural changes [Lampitt et al., 2008]. It may be possible to extract the $\mathrm{Mg}$ or $\mathrm{Ca}$ from a 
silicate mineral (thus minimizing $\mathrm{Si}$ and $\mathrm{Fe}$ added to the ocean) to create pure oxides or hydroxides, however the technology to do this has yet to be developed.

\subsection{Localized elevated $\mathrm{pH}$ and reduced aqueous $\mathrm{CO}_{2}$}

In marine aquaria, 'calcium reactors' (that cycle the aquarium water through a bed of crushed limestone), or 'Kalkwasser' (a solution of $\mathrm{Ca}(\mathrm{OH})_{2}$ ), are widely used to prevent problematic decreases in $\mathrm{pH}$ caused by respiration and nitrification. As such, alkalinity is typically maintained between 3-6 mEq kg-1 [Tullock and Earle-Bridges 2002]. Even if sufficient alkalinity were introduced to the ocean mitigate all of anthropogenic $\mathrm{CO}_{2}$ emissions for the next 100 years, it is not anticipated to greatly exceed $4 \mathrm{mEq} \mathrm{kg}{ }^{-1}$. The first order impact of increasing $\left[\mathrm{CO}_{3}{ }^{2-}\right]$ and $\left[\mathrm{HCO}_{3}{ }^{-}\right]$in seawater is probably minimal. However, addition of alkalinity may induce transient elevated $\mathrm{pH}$ and/or lower $\left[\mathrm{CO}_{2}(\mathrm{aq})\right]$ around the point of addition (except AWL, which would likely result in elevated $\left[\mathrm{CO}_{2(\mathrm{aq})}\right]$ around the reactor outlet). Feng et al., [2016] suggest that it may be possible to influence carbonate chemistry at a regional scale (e.g., South China Sea, the Great Barrier Reef). However, the application rate of alkalinity would need to be large to have the desired effect. Ecosystems could also be exposed to the risk of rapid changes in chemistry should the addition be halted.

All autotrophic organisms have evolved strategies to concentrate carbon during photosynthesis. This is to compensate $\mathrm{CO}_{2}$ undersaturation in the modern atmosphere (and thus ocean) for Rubisco (the enzyme which catalyzes photosynthesis; Henderson et al., 2008). Therefore, transient reductions in aqueous $\mathrm{CO}_{2}$ caused by alkalinity addition could inhibit photosynthesis, and thus alter the function and structure of phytoplankton communities. Henderson et al., [2008] suggest that changes within the structure of these primary producers, could have important implications for the function of whole marine ecosystems. For instance, reduced rates of carbon and nitrogen fixation have been demonstrated in cyanobacterium Trichodesmium (an important primary producer) at low $\mathrm{pCO}_{2}$ [Hutchins et al., 2007; Ramos et al., 2007].

Scott et al., [2005] found reduced sodium uptake and ammonia excretion in Perca fluviatilis (Perch) exposed to a $\mathrm{pH} 9.5$ (through potassium hydroxide addition). The $\mathrm{Na}^{+}$imbalance is thought to allow the fish to retain $\mathrm{H}^{+}$and mitigate the effects of alkalosis (elevated blood $\mathrm{pH}$ ). Higher ammonia retention is a result of a lower concentration gradient across the gills caused by a decrease in the amount of ammonia converted to ammonium at the interface with high $\mathrm{pH}$ water [Saha et al., 2002]. In a toxicology study, Locke et al., (2009) suggest that between 100$320 \mathrm{mg} \mathrm{l}^{-1}\left(1.3-4.4\right.$ mmoles $\mathrm{l}^{-1}$, resulting in a $\left.\mathrm{pH}>10\right)$ of $\mathrm{Ca}(\mathrm{OH})_{2}$ is needed to have a detectable impact on the mortality of Gasterosteus aculeatus (a common coastal fish) over 96 days. Fish and mammals have developed renal compensation in order to excrete excess alkalinity [Wood et al., 1999], but prolonged exposure may have a chronic impact.

In a single species experiment, Cripps et al., [2013] investigated the impact of $\mathrm{Ca}(\mathrm{OH})_{2}$ addition on Carcinus maenas (a globally distributed crab species). The experiments (ranging from $\mathrm{pH} 8.5$ to $8.8, \mathrm{pCO}_{2} 200$ to $80 \mu \mathrm{atm}, \Omega_{\text {calcite }}=7$ to 13 ) demonstrated respiratory alkalosis possibly in response to lower levels of aqueous $\mathrm{CO}_{2}$. However, the authors note that these fluctuations are smaller than the daily changes experienced in intertidal rock pools, and it is not clear how an elevated ambient $\mathrm{pH}$ may impact the overall fluctuations in coastal 
environments. Locke et al., [2009] suggest Crangon septemspinosa (a common shrimp species) is sensitive to $\mathrm{Ca}(\mathrm{OH})_{2}$ addition, with $100 \%$ mortality for $\sim 100 \mathrm{mg} \mathrm{l}^{-1}$ addition after 14 days. Bivalves appear to have less control on the $\mathrm{pH}$ within their blood, and are possibly more sensitive to environmental changes [Byrne and Dietz 1997], although control may be unnecessary for anything other than shell formation [Booth et al., 1984].

\subsection{Localized changes in dissolved oxygen}

Dissolved oxygen in the ocean is controlled by a number of mechanisms including the biogenic production at the surface, respirative removal from remineralization of sinking organic matter, ocean-atmosphere gas exchange, and circulation [Joos et al., 2003]. The deleterious anthropogenic impact on dissolved oxygen is a concern and could increase the extent of oxygen minimum zones [Stramma et al., 2008]. Hypoxia alters benthic ecosystem structure and function, in which smaller taxa are more resilient than larger [Levin et al., 2009]. Although in a modest lime addition scenario (Keller et al., [2014]; equating to cumulative draw down of around $160 \mathrm{Gt} \mathrm{C}$ by 2100) no change in dissolved $\mathrm{O}_{2}$ was demonstrated.

Fertilizing biological activity through the addition of iron and silicon (or increased export through ballasting) may increase dissolved oxygen in the photic zone, but reduce it in the waters below due to remineralization of exported organic carbon [Fuhrman and Capone 1991]. Further to biological oxygen removal, fayalite $\left(\mathrm{Fe}_{2} \mathrm{SiO}_{4}\right)$, the iron end member of olivine is composed of $\mathrm{Fe}^{2+}$ which oxidizes to $\mathrm{Fe}^{3+}$ during dissolution in the presence of oxygen ([Schott and Berner 1985]; equation 34).

$$
\mathrm{Fe}_{2} \mathrm{SiO}_{4}+\frac{1}{2} \mathrm{O}_{2} \rightarrow \mathrm{Fe}_{2} \mathrm{O}_{3}+\mathrm{SiO}_{2} \quad \text { equation } 34
$$

An ophiolite may contain between 0 and $20 \% \mathrm{FeO}$ [Miyashiro 1975]. A rock with a fayalite to forsterite mass ratio of 1:9 (FeO 7\%) would consume approximately $12 \mathrm{~g} \mathrm{O}_{2}$ for every $\mathrm{kg}$ dissolved. A column of water in the mixed layer $\left(1 \mathrm{~m}^{2}\right.$ by $60 \mathrm{~m}$ deep) could contain on the order of 10 moles of $\mathrm{O}_{2}\left(\sim 200\right.$ moles $\mathrm{kg}^{-1}$, [Stramma et al., 2008]). It would therefore take around $25 \mathrm{~kg} \mathrm{~m}^{-2}$ of rapidly dissolving rock to completely remove $\mathrm{O}_{2}$ as it sank through the water column. During the European Iron Fertilization Experiment [Smetak et al., 2007], 7 tons of material was rapidly (within 1 day) spread over a $167 \mathrm{~km}^{2}$ patch $\left(10^{-4.4} \mathrm{~kg} \mathrm{~m}^{-2}\right)$, which over the following 14 days increased to $740 \mathrm{~km}^{2}\left(10^{-5} \mathrm{~kg} \mathrm{~m}^{-2}\right)$. It is therefore possible that oxygen consumption from iron oxidation can be easily mitigated with suitable addition rates, and exploiting rapid dilution in the mixed layer. However, the effects may be more significant in poorly mixed waters, waters with existing hypoxia, and sediments and soils.

\subsection{Alkalinity addition in shell fish production and coral reef protection}

Lime and hydrated lime have been used for almost a century to control invasive species in shellfish aquaculture (see Locke et al., [2009], and references therein). This involves dipping an entire sock of shellfish into a concentrated solution of lime/quicklime, or spraying a concentrated solution onto a bed [Piola et al., 2009]. For instance, Switzer et al., [2011] report that the addition of $\mathrm{Ca}(\mathrm{OH})_{2}$ was effective at controlling the invasive species of Didemnum vexillum (carpet sea squirt) on commercial oysters. However, at one of the treatment sites they report a considerable reduction in the survival rate the stock (although $\mathrm{pH}$ remained at ambient levels). This demonstrates the relative sensitivity of species to large transient doses of $\mathrm{Ca}(\mathrm{OH})_{2}$. However, Locke et al. [2009] suggests that targeted lime addition to these environments may 
be able to minimize the impact of ocean acidification or improve water quality in anaerobic estuaries from excess nutrient load.

Given the relative sensitivity of species to lime addition, its use for mitigating the effects of ocean acidification in natural environments requires careful consideration. The addition rate would have to be sufficient to overcome mixing of the local seawater with the ambient environment, but not sufficient to detrimentally impact ecosystems. Work is required to assess locations in which this may be feasible, and how such a scheme may operate.

\subsection{Regulation and ethics of adding alkalinity to the ocean}

The 1982 United Nations Convention on the Law of the Sea (LOSC [UN 1982]) lays down the legal framework for almost all matters relating to the seas and oceans. Carbon storage as alkalinity, as a novel marine activity, is not explicitly addressed in the Convention. Nevertheless, the provisions of the LOSC are generally applicable, setting out the territorial and economic claims of sovereign states, responsibilities for the protection of the marine environment, marine scientific research, and dispute resolution. The LOSC also provides for the development of specific and detailed norms under the Convention for new and emerging marine activities. Within this context, the issue of marine geoengineering was recently addressed under the London Convention and London Protocol [IMO 2003] (LC/LP), treaties that regulate marine pollution from the dumping of wastes or other matter at sea. The texts of these instruments excludes the 'placement of matter for a purpose other than the mere disposal thereof, provided that such placement is not contrary to the aims of this Protocol' from the definition of dumping and would therefore apparently exclude the addition of alkalinity to the ocean from falling under these regimes. However, in the case of ocean fertilization the Parties to the London Convention and the London Protocol determined in 2008 that the scope of the London Convention and Protocol includes ocean fertilization activities' due to significant risk that such placement would be contrary to the aims of both the London Convention and the London Protocol. Subsequently, the London Protocol was amended in October 2013 (London Protocol Resolution LP.4(8) - [IMO 2008]) to regulate ocean fertilization activities, and also enables the Parties to regulate other marine geoengineering activities in the future, potentially including the addition of alkalinity to the ocean. The amendments need to be ratified by $2 / 3 \mathrm{rds}$ of the Contracting Parties to come into force, which would provide a legally binding mechanism to regulate ocean fertilization, with the possibility of regulating other marine geoengineering activities in the future. On the face of it, carbon storage as alkalinity falls within the definition of 'marine geoengineering' as 'a deliberate intervention in the marine environment to manipulate natural processes, including to counteract anthropogenic climate change and/or its impacts, and that has the potential to result in deleterious effects, especially where those effects may be widespread, long-lasting or severe.' Hence, though the amendment to the London Protocol is not yet in force, there remains a possibility that the addition of alkalinity to the ocean could be regulated at a later date as a placement of matter into the sea for marine geoengineering purposes. Therefore, the addition of alkalinity to the ocean would likely operate under a complicated regulatory framework. Addition to coastal waters would fall under national (or regional) administration, whereas open ocean addition would require international oversight.

Beyond this, efforts have been undertaken to contribute to the development of an effective governance framework for geoengineering, a term which commonly covers several ocean 
alkalinity proposals. Rayner et al., [2013] have laid out a set of guiding ('Oxford') principles for geoengineering, including: 1) that it be regulated as a public good; 2) public participation in decision-making; 3) disclosure of research and open publication of results; 4) independent assessment of impacts; and 5) governance before deployment. This wider discussion has highlighted the responsibilities of researchers working on proposals that may eventually lead to widespread or intended impact [Owen et al., 2013]. With this in mind, Hubert and Reichwein [2015] suggest a means to codify norms for research within this space, deliberating on the foundational principles (e.g., prevention and precaution), the responsibility of states to prevent activity without prior assessment of harms, and the responsibility of scientists to design and undertake proportional step-by-step activates to further scientific understanding.

\subsection{Monitoring}

It is possible to achieve precision of less than $0.005 \mathrm{mEq} \mathrm{kg}^{-1}(0.02 \%)$ in routine measurements of seawater alkalinity [Dickson et al., 2007]. This suggests that an addition of $0.005-0.015$ $\mathrm{mEq} \mathrm{kg} \mathrm{a}^{-1} \mathrm{a}^{-1}$ could be detected. However, it may be several years before this signal is detectable above the background seasonal variability $\left(0-0.08 \mathrm{mEq} \mathrm{kg}^{-1}\right)$. A key limitation will likely be the ability to collect the appropriate amount of samples/data in a short enough time period to accurately quantify alkalinity changes across the whole ocean. Over the last 35 years ocean alkalinity data were collected as part of 42 cruises at 23,000 stations (see CDIAC's ocean carbon data collection http://cdiac.ornl.gov/oceans/). The collection of data from scientific cruises would likely form an important part of an ocean alkalinity monitoring system. However, automated monitoring systems are becoming increasingly common, which currently omit alkalinity or carbonate system measurements, but will likely include these in the near future [GOOS 2006].

\section{Conclusions and further work}

Storage of large volumes of $\mathrm{CO}_{2}$ may be necessary to prevent dangerous climate change. This paper explores the issues surrounding the chemical transformation of $\mathrm{CO}_{2}$ through mineral dissolution for storage as ocean alkalinity $\left(\mathrm{HCO}_{3}{ }^{-} \mathrm{CO}_{3}{ }^{2-}\right.$ ions). The ocean currently stores around $38,000 \mathrm{Gt} \mathrm{C}$ (equivalent to $\sim 140,000 \mathrm{Gt} \mathrm{CO}_{2}$ ) in this way, and may be able to store trillions of tons of $\mathrm{CO}_{2}$ with limited changes in bulk chemistry. If it were used as the sole destination of all anthropogenic $\mathrm{CO}_{2}$ emissions over the next $100-500$ a, then ocean alkalinity would increase from current levels of $2.3 \mathrm{mEq} \mathrm{kg}{ }^{-1}$ to $\sim 3 \mathrm{mEq} \mathrm{kg}^{-1}$ (resulting in a calcite saturation level of between 5 and 7.5). Considering these changes as an upper end member, it is unlikely that the average saturation state of calcite will surpass its pre-industrial level, although some environments may be more sensitive than others.

Transient localized impact around the point of alkalinity addition could be substantial. On one hand, it may be possible to ameliorate the effects of ocean acidification (i.e. maintaining the saturation state of calcite at an appropriate value) by controlled addition to sensitive environments. However, rapid uncontrolled changes in $\mathrm{pH}$, carbonate saturation state, and dissolved aqueous $\mathrm{CO}_{2}$ may have detrimental effects on ocean ecosystems. The source of alkalinity may be derived from carbonate or silicate minerals. Direct addition of the latter to the ocean may fertilize biological activity through the co-dissolution of nutrients (e.g., iron and silicon), although it may be possible to extract the magnesium or calcium prior to addition. While the addition of alkalinity is common in several marine environments (e.g., in aquaria and shellfish production), more research is needed to constrain the wider ecosystem response. 
Table 2 provides a range of carbonate system parameters that could be used as a basis for this experimental work.

Carbonate mineral precipitation is strongly inhibited in seawater, and is almost exclusively produced from biological activity. In the global carbon cycle, up to $2 \mathrm{Gt} \mathrm{C}^{-1}$ is incorporated into carbonate shells in the ocean, of which only $<0.3 \mathrm{Gt} \mathrm{C} \mathrm{a}^{-1}$ makes it into the lithosphere. The remainder is re-mineralized into dissolved aqueous species (into $\mathrm{CO}_{2}, \mathrm{HCO}_{3}{ }^{-}$and $\mathrm{CO}_{3}{ }^{2-}$ ). As such, the residence time for alkalinity in the ocean is on the order of $100-1,000 \mathrm{ka}$, and would form, for all practical purposes, a permanent sink for anthropogenic $\mathrm{CO}_{2}$. However, raised alkalinity in the ocean may change the rate of carbonate mineral production (both biogenic and abiological), but more experimental work is required to constrain this change. Research investigating the change of shell mass with carbonate ion concentration suggest a growth rate change between $10-80 \%$ for calcite saturation state of 7 , which is considerably less than the expected abiological increase of $140 \%$. Increased alkalinity will also likely reduce the rate at which carbonate is re-mineralized in sediments, and increase the depth of the ocean in which carbonate minerals are thermodynamically unstable ('lysocline'), and thus increase carbonate burial. An increased carbonate production or decrease in remineralization will lower, or reverse, the effectiveness of ocean alkalinity carbon storage. It is possible that increased carbonate production and ballasting will also increase the export of organic carbon. As the particulate organic to inorganic carbon ratio is $>1$, the effect may result in the additional drawdown of atmospheric $\mathrm{CO}_{2}$. Considerably more work is required to understand the longevity of carbon storage as elevated alkalinity in the ocean.

A range of techniques have been proposed for increasing ocean alkalinity, which exploit numerous reaction pathways (Table 1). However, all require the extraction, processing, and reaction of rocks. It may be possible to achieve $\mathrm{CO}_{2}$ :rock mass ratios $>1$ using ultrabasic minerals (larger than the $\sim 0.6$ mass ratio for solid carbonate formation). It may also be possible to use faster dissolving carbonate minerals for alkalinity addition $\left(\mathrm{CO}_{2}\right.$ : rock mass ratio $\left.\sim 0.5\right)$. While some components of these processes already operate at a large scale (e.g., the production of lime), generally the overall technologies have not developed beyond desk-top technoeconomic assessment or bench scale laboratory work. However, this work suggests some of the proposals to have a range of energy requirements and financial costs comparable to more widely studied alternatives (e.g., 1-10 GJ tCO ${ }_{2}^{-1}, \$ 50-150 \mathrm{tCO}_{2}^{-1}$ ). However, up-scaling these processes to have an impact on anthropogenic $\mathrm{CO}_{2}$ emissions (i.e. billions of tons $\mathrm{CO}_{2} \mathrm{a}^{-1}$ ) is a considerable challenge (as it is for mineral carbonation).

Finally, the modification of the ocean (a global commons) raises issues surrounding regulation, monitoring, and the distribution of impact. The London Convention/Protocol was created to limit dumping of materials in the ocean, and has been amended (yet to be ratified) to include marine geoengineering proposals. More work is required to develop governance for ocean alkalinity carbon storage, but this should be informed by, and tailored to, the potential harms and benefits of specific alkalinity addition approaches.

\section{$9 \quad$ Acknowledgements}

The authors would like to thank Yves Plancherel (University of Oxford) for producing Figure 4 and 5, and David Sansom (University of Oxford) for drafting Figures 3 and 6. Furthermore, Steve Barker (Cardiff University), Martin Bunzl (Rutgers University), Ken Caldeira (Carnegie Institution for Science) Michaël Hermoso (University of Oxford), Clare Heyward (University 
of Warwick), Anna-Maria Hubert (University of Calgary), Greg Rau (University of California, Santa Cruz), and Chris Vivian (Cefas) for conversations and feedback during the preparation of this work. Miriam Ferrer-González (Max Planck Institute for Meteorology) and David Keller (GEOMAR) are thanked for making their data available for Figure 8. Andy Ridgwell and John Shepherd are thanked for their constructive reviews. The authors acknowledge funding from the Oxford Martin School through the Oxford Geoengineering Programme, and from the Hay Family. Supporting information for this manuscript is available online.

\section{References}

Addadi, L., Joester, D., Nudelman, F., Weiner, S., 2006. Mollusk Shell Formation: A Source of New Concepts for Understanding Biomineralization Processes. Chem. - Eur. J. 12, 980-987. doi:10.1002/chem.200500980

Aldridge, D., Beer, C., Purdie, D., 2012. Calcification in the planktonic foraminifera Globigerina bulloides linked to phosphate concentrations in surface waters of the North Atlantic Ocean. Biogeosciences 9, 1725-1739. doi:10.5194/bg-9-1725-2012

Alldredge, A.L., Silver, M.W., 1988. Characteristics, dynamics and significance of marine snow. Prog. Oceanogr. 20, 41-82. doi:10.1016/0079-6611(88)90053-5

Andersson, A.J. 2014. The oceanic $\mathrm{CaCO}_{3}$ cycle. Treatise on Geochemistry. (Holland HD, Turekian KK, Eds.). 8. 519-542. Oxford: Elsevier. Doi: 10.1016/B978-0-08-0959757.00619-7

Archer D., Buffett B., Brovkin V. 2009. Ocean methane hydrates as a slow tipping point in the global carbon cycle. Proc. Natl. Acad. Sci. U. S. A. 106 (49) 20596-20601. doi: 10.1073/pnas.0800885105

Archer, D., A. Winguth, D. Lea, and N. Mahowald (2000), What caused the glacial/interglacial atmospheric pCO2 cycles?, Rev. Geophys., 38(2), 159-189, doi:10.1029/1999RG000066.

Astilleros, J.M., Fernández-Díaz, L., Putnis, A., 2010. The role of magnesium in the growth of calcite: An AFM study. Chem. Geol. 271, 52-58. doi:10.1016/j.chemgeo.2009.12.011

Bach, L.T., Riebesell, U., Schulz, K.G., 2011. Distinguishing between the effects of ocean acidification and ocean carbonation in the coccolithophore Emiliania huxleyi. Limnol. Oceanogr. 56, 2040-2050. doi:10.4319/lo.2011.56.6.2040

Balch, W.M., Gordon, H.R., Bowler, B.C., Drapeau, D.T., Booth, E.S., 2005. Calcium carbonate measurements in the surface global ocean based on Moderate-Resolution Imaging Spectroradiometer data. J. Geophys. Res. Oceans 110, C07001, doi:10.1029/2004JC002560

Ball, J.W., and Nordstrom, D.K., 1991, WATEQ4F--User's manual with revised thermodynamic data base and test cases for calculating speciation of major, trace and redox elements in natural waters: U.S. Geological Survey Open-File Report 90-129, $185 \mathrm{p}$.

Barker, S., Archer, D., Booth, L., Elderfield, H., Henderiks, J., Rickaby, R.E.M., 2006. Globally increased pelagic carbonate production during the Mid-Brunhes dissolution interval and the CO2 paradox of MIS 11. Crit. Quat. Stratigr. 25, 3278-3293. doi:10.1016/j.quascirev.2006.07.018

Barker, S., Elderfield, H., 2002. Foraminiferal calcification response to glacial-interglacial changes in atmospheric $\mathrm{CO}_{2}$. Science 297, 833-836. doi: 10.1126/science.1072815

Beer, C.J., Schiebel, R., Wilson, P.A., 2010. Testing planktic foraminiferal shell weight as a surface water $\left[\mathrm{CO}_{3}{ }^{2-}\right]$ proxy using plankton net samples. Geology 38, 103-106. doi: $10.1130 / \mathrm{G} 30150.1$ 
Bellamy, R., Chilvers, J., Vaughan, N.E., Lenton, T.M., 2012. A review of climate geoengineering appraisals. WIREs. Clim. Change 3, 597-615. doi:10.1002/wcc.197

Berner, R.A., 1975. The role of magnesium in the crystal growth of calcite and aragonite from sea water. Geochim. Cosmochim. Acta 39, 489-504. doi:10.1016/00167037(75)90102-7

Berner, R.A., Lasaga, A.C., Garrels, R.M., 1983. The carbonate-silicate geochemical cycle and its effect on atmospheric carbon-dioxide over the past 100 million years. Am. J. Sci. 283, 641-683. doi: 10.2475/ajs.283.7.641

Bijma, J., Hönisch, B., Zeebe, R.E., 2002. Impact of the ocean carbonate chemistry on living foraminiferal shell weight: Comment on "Carbonate ion concentration in glacial-age deep waters of the Caribbean Sea" by W. S. Broecker and E. Clark. Geochem. Geophys. Geosystems 3, 1-7. doi:10.1029/2002GC000388

Booth, C. E., McDonald, D. G., Walsh. P. J., 1984. Acid-base balance in the sea mussel Mytihrs edulis. 1. Effects of hypoxia and air exposure on the hemolymph acid-base status. Mar. Biol. Lett. 5: 347-358.

Bots, P., Benning, L.G., Rickaby, R.E.M., Shaw, S., 2011. The role of $\mathrm{SO}_{4}$ in the switch from calcite to aragonite seas. Geology 39, 331-334. doi: 10.1130/G31619.1

Boyle, E.A., 1988. The role of vertical chemical fractionation in controlling late Quaternary atmospheric carbon dioxide. J. Geophys. Res. Oceans 93, 15701-15714. doi: 10.1029/JC093iC12p15701

Bradshaw, J., Bachu, S., Bonijoly, D., Burruss, R., Holloway, S., Christensen, N.P., Mathiassen, O.M., 2007. $\mathrm{CO}_{2}$ storage capacity estimation: Issues and development of standards. Int. J. Greenh. Gas Control 1, 62-68.

Brinkmann, T., Santonja, G.G., Schorcht, F., Roudier, S., Sancho, L.D., 2014. Best Available Techniques (BAT) Reference Document for the Production of Chlor-alkali.

Publications office of the European Union. EUR 26844, OPOCE LF-NA-26844-ENN doi: 10.2791/13138

Broecker, W.S., Langdon, C., Takahashi, T., Peng, T.-H., 2001. Factors controlling the rate of $\mathrm{CaCO}_{3}$ precipitation on Great Bahama Bank. Glob. Biogeochem. Cycles 15, 589596. doi:10.1029/2000GB001350

Broecker, W.S., Takahashi, T., 1966. Calcium carbonate precipitation on the Bahama Banks. J. Geophys. Res. 71, 1575-1602. doi:10.1029/JZ071i006p01575

Burton, E.A., Walter, L.M., 1990. The role of $\mathrm{pH}$ in phosphate inhibition of calcite and aragonite precipitation rates in seawater. Geochim. Cosmochim. Acta 54, 797-808. doi:10.1016/0016-7037(90)90374-T

Burton, E.A., Walter, L.M., 1987. Relative precipitation rates of aragonite and Mg calcite from seawater: Temperature or carbonate ion control? Geology 15, 111-114.

Busenberg, E., Plummer, L.N., 1985. Kinetic and thermodynamic factors controlling the distribution of $\mathrm{SO}_{3}{ }^{2-}$ and $\mathrm{Na}^{+}$in calcites and selected aragonites. Geochim. Cosmochim. Acta 49, 713-725.

Bustos-Serrano, H., Morse, J.W., Millero, F.J., 2009. The formation of whitings on the Little Bahama Bank. Mar. Chem. 113, 1-8. doi:10.1016/j.marchem.2008.10.006

Byrne, C.D., Law, R.J., Hudson, P.M., Thain, J.E., Fileman, T.W., 1988. Measurements of the dispersion of liquid industrial waste discharged into the wake of a dumping vessel. Water Res. 22, 1577-1584. doi:10.1016/0043-1354(88)90171-6

Byrne, R., Dietz, T., 1997. Ion transport and acid-base balance in freshwater bivalves. J. Exp. Biol. 200, 457-465.

Cai, W.-J., Hu, X., Huang, W.-J., Jiang, L.-Q., Wang, Y., Peng, T.-H., Zhang, X., 2010. Alkalinity distribution in the western North Atlantic Ocean margins. J. Geophys. Res. Oceans 115, C08014 doi:10.1029/2009JC005482 
Caldeira, K., Rau, G.H., 2000. Accelerating carbonate dissolution to sequester carbon dioxide in the ocean: Geochemical implications. Geophys. Res. Lett. 27, 225-228. doi:10.1029/1999GL002364

Carter, B. R., Toggweiler, J. R., Key, R. M., Sarmiento, J. L. 2014. Processes determining the marine alkalinity and calcium carbonate saturation state distributions, Biogeosciences, 11, 7349-7362, doi:10.5194/bg-11-7349-2014, 2014.

CEFIC, 2011. Guidelines for measuring and managing $\mathrm{CO}_{2}$ emission from freight transport operations. The European Chemical Industry Council - ECTA.

Chou, H.-T., 1996. On the dilution of liquid waste in ships' wakes. J. Mar. Sci. Technol. 1, 149-154. doi:10.1007/BF02391175

Chou, W.-C., Gong, G.-C., Hsieh, P.-S., Chang, M.-H., Chen, H.-Y., Yang, C.-Y., Syu, R.W., 2015. Potential impacts of effluent from accelerated weathering of limestone on seawater carbon chemistry: A case study for the Hoping power plant in northeastern Taiwan. Mar. Chem. 168, 27-36. doi:10.1016/j.marchem.2014.10.008

Chuck, A., Tyrrell, T., Totterdell, I.J., Holligan, P.M., 2005. The oceanic response to carbon emissions over the next century: investigation using three ocean carbon cycle models. Tellus B 57, 70-86. doi:10.1111/j.1600-0889.2005.00127.x

Ciais, P., Sabine, C., Bala, G., Bopp, L., Brovkin, V., Canadell, J., Chhabra, A., DeFries, R., Galloway, J., Heimann, M., 2014. Carbon and other biogeochemical cycles, in: Climate Change 2013: The Physical Science Basis. Contribution of Working Group I to the Fifth Assessment Report of the Intergovernmental Panel on Climate Change. Cambridge University Press, pp. 465-570.

Cloud Jr., P.E., 1962. Behaviour of calcium carbonate in sea water. Geochim. Cosmochim. Acta 26, 867-884. doi:10.1016/0016-7037(62)90117-5

Cockell, C.S. 2011. Biological Volcanic Rock Weathering. Encyclopedia of Geobiology. 143147. doi: 10.1007/978-1-4020-9212-1_219. ISBN 978-1-4020-9211-4

Comeau, S., Gorsky, G., Jeffree, R., Teyssié, J.-L., Gattuso, J.-P., 2009. Impact of ocean acidification on a key Arctic pelagic mollusc (Limacina helicina). Biogeosciences 6, 1877-1882. doi:10.5194/bg-6-1877-2009

Cripps, G., Widdicombe, S., Spicer, J.I., Findlay, H.S., 2013. Biological impacts of enhanced alkalinity in Carcinus maenas. Mar. Pollut. Bull. 71, 190-198. doi:http://dx.doi.org/10.1016/j.marpolbul.2013.03.015

Cubillas, P., Köhler, S., Prieto, M., Chaïrat, C., Oelkers, E.H., 2005. Experimental determination of the dissolution rates of calcite, aragonite, and bivalves. Chem. Geol. 216, 59-77. doi:10.1016/j.chemgeo.2004.11.009

Davies, P.A., 2015. Solar thermal decomposition of desalination reject brine for carbon dioxide removal and neutralisation of ocean acidity. Environ. Sci. Water Res. Technol. 1, 131-137. doi:10.1039/C4EW00058G

Davis, K.J., Dove, P.M., De Yoreo, J.J., 2000. The Role of $\mathrm{Mg}^{2+}$ as an Impurity in Calcite Growth. Science 290, 1134-1137. doi: 10.1126/science.290.5494.1134

Davis, S.J., Long, C., and Caldeira, K., Hoffert, M.I. 2013. Rethinking wedges. Environ. Res. Lett. 8, 011001. Doi: 10.1088/1748-9326/8/1/011001

Davis, S.C., Diegel, S.E., Boundy, R.G., 2011. Transportation energy data book: Edition 30. Centre for Transportation Analysis: Energy and Transportation Science Division.

DECC, 2010 Department for Energy and Climate Change. URN 10D/764. https://www.gov.uk/government/publications/2050-pathways-analysis

DECC, 2015. Digest of UK energy statistics'. Department for Energy and Climate Change.

Delft, 1970. Studies on the mixing of dilute acid with seawater in the propeller slipstream of the coaster "Kathe H." Waterloopkundig Laboratory Delft M939. 
Delvigne, G.A.L., 1987. Experiments on the dilution capacity of wakes from tankers dumping in the North Sea. Krieger, Malabar, Florida. Oceanic processes in marine pollution. 2. 11-19. in physicochemical processes and wastes in the ocean O'Connor, T.P.; Burt, W.V.; Duedall, I.W., (editors).

Denman, K.L., 2008. Climate change, ocean processes and ocean iron fertilization. Marine Ecology Progress Series 364, 219-225.

Dickson, A.G., 1981. An exact definition of total alkalinity and a procedure for the estimation of alkalinity and total inorganic carbon from titration data. Deep Sea Research Part A. Oceanographic Research Papers 28, 609-623. doi:10.1016/0198-0149(81)90121-7

Dickson, A.G. 1990 Standard potential of the $(\mathrm{AgCl}(\mathrm{s})+12 \mathrm{H} 2(\mathrm{~g})=\mathrm{Ag}(\mathrm{s})+\mathrm{HCl}(\mathrm{aq}))$ cell and the dissociation of bisulfate ion in synthetic sea water from 273.15 to $318.15 \mathrm{~K}$. $J$. Chem. Thermodyn. 22 113-127.

Dickson, A.G., Sabine, C.L. and Christian, J.R. (Eds.) 2007. Guide to best practices for ocean $\mathrm{CO}_{2}$ measurements. PICES Special Publication 3, $191 \mathrm{pp}$.

Doney, S.C., Fabry, V.J., Feely, R.A., Kleypas, J.A., 2009. Ocean Acidification: The Other $\mathrm{CO}_{2}$ Problem. Annu. Rev. Mar. Sci. 1, 169-192. doi:10.1146/annurev.marine.010908.163834

Drever, J.I., 1988. The geochemistry of natural waters. Prentice Hall Englewood Cliffs.

Edenhofer O., R. Pichs-Madruga, Y. Sokona, S. Kadner, J.C. Minx, S. Brunner, S. Agrawala, G. Baiocchi, I.A. Bashmakov, G. Blanco, J. Broome, T. Bruckner, M. Bustamante, L. Clarke, M. Conte Grand, F. Creutzig, X. Cruz-Núñez, S. Dhakal, N.K. Dubash, P. Eickemeier, E. Farahani, M. Fischedick, M. Fleurbaey, R. Gerlagh, L. GómezEcheverri, S. Gupta, J. Harnisch, K.Jiang, F. Jotzo, S. Kartha, S. Klasen, C. Kolstad, V. Krey, H. Kunreuther, O. Lucon, O. Masera, Y. Mulugetta, R.B. Norgaard, A. Patt, N.H. Ravindranath, K. Riahi, J. Roy, A. Sagar, R. Schaeffer, S. Schlömer, K.C. Seto, K. Seyboth, R. Sims, P. Smith, E. Somanathan, R. Stavins, C. von Stechow, T. Sterner, T. Sugiyama, S. Suh, D. Ürge-Vorsatz, K. Urama, A. Venables, D.G. Victor, E. Weber, D. Zhou, J. Zou, and T. Zwickel, 2014: Technical Summary. In: Climate Change 2014: Mitigation of Climate Change. Contribution of Working Group III to the Fifth Assessment Report of the Intergovernmental Panel on Climate Change [Edenhofer, O., R. Pichs-Madruga, Y. Sokona, E. Farahani, S. Kadner, K. Seyboth, A. Adler, I. Baum, S. Brunner, P. Eickemeier, B. Kriemann, J. Savolainen, S. Schlömer, C. von Stechow, T. Zwickel and J.C. Minx (eds.)]. Cambridge University Press, Cambridge, United Kingdom and New York, NY, USA.

Fabry, V.J., Seibel, B.A., Feely, R.A., Orr, J.C., 2008. Impacts of ocean acidification on marine fauna and ecosystem processes. ICES J. Mar. Sci. J. Cons. 65, 414-432. doi:10.1093/icesjms/fsn048

Fagerlund, J., Nduagu, E., Romão, I., Zevenhoven, R., 2012. CO2 fixation using magnesium silicate minerals part 1: Process description and performance. 23rd Int. Conf. Effic. Cost Optim. Simul. Environ. Impact Energy Syst. ECOS 2010 41, 184-191. doi:10.1016/j.energy.2011.08.032

Feng, E.Y. (冯玉铭), Keller, D. P., Koeve, W., Oschlies, A., 2016. Could artificial ocean alkalinization protect tropical coral ecosystems from ocean acidification? Environ. Res. Lett. 11, 074008. doi: 10.1088/1748-9326/11/7/074008

Fernández-Díaz, L., Fernández-González, Á., Prieto, M., 2010. The role of sulfate groups in controlling $\mathrm{CaCO}_{3}$ polymorphism. Geochim. Cosmochim. Acta 74, 6064-6076. doi:10.1016/j.gca.2010.08.010

Ferrer-González, M., Ilyina, T., 2016. Impacts of artificial ocean alkalinization on the carbon cycle and climate in Earth system simulations. Geophys. Res. Lett. 43, 6493-6502. doi:10.1002/2016GL068576 
Frankignoulle M., Canon C., Gattuso J. 1994. Marine calcification as a source of carbon dioxide: Positive feedback of increasing atmospheric $\mathrm{CO}_{2}$. Limnol. Oceanogr., 39, 458-462 doi: 10.4319/lo.1994.39.2.0458.

Fuhrman, J.A., Capone, D.G., 1991. Possible biogeochemical consequences of ocean fertilization. Limnol. Oceanogr. 36, 1951-1959. doi:10.4319/lo.1991.36.8.1951

Fuss, S., Canadell, J.G., Peters, G.P., Tavoni, M., Andrew, R.M., Ciais, P., Jackson, R.B., Jones, C.D., Kraxner, F., Nakicenovic, N., Le Quere, C., Raupach, M.R., Sharifi, A., Smith, P., Yamagata, Y., 2014. Betting on negative emissions. Nat. Clim Change 4, 850-853. doi:10.1038/nclimate2392

Gaillardet, J., Dupré, B., Louvat, P., Allègre, C.J., 1999. Global silicate weathering and CO2 consumption rates deduced from the chemistry of large rivers. Chem. Geol. 159, 3-30. doi:10.1016/S0009-2541(99)00031-5

Gattuso, J.-P., Frankignoulle, M., Bourge, I., Romaine, S., Buddemeier, R.W., 1998. Effect of calcium carbonate saturation of seawater on coral calcification. Glob. Planet. Change 18, 37-46. doi:10.1016/S0921-8181(98)00035-6

Godoi, R.H.M., Aerts, K., Harlay, J., Kaegi, R., Ro, C.-U., Chou, L., Van Grieken, R., 2009. Organic surface coating on Coccolithophores - Emiliania huxleyi: Its determination and implication in the marine carbon cycle. Microchem. J. 91, 266-271. doi:10.1016/j.microc.2008.12.009

GOOS, 2006. Joint GCOS-GOOS-WCRP Ocean Observations Panel for Climate (OOPC). GCOS Report No. 110 FINAL DRAFT, GOOS Report No. 154, WCRP Report No. n/2007. http://ioc.unesco.org/oopc/oopc-11/

Hangx, S.J.T., Spiers, C.J., 2009. Coastal spreading of olivine to control atmospheric $\mathrm{CO}_{2}$ concentrations: A critical analysis of viability. Int. J. Greenh. Gas Control 3, 757767. Doi: 10.1016/j.ijggc.2009.07.001

Hartmann, J., Kempe, S., 2008. What is the maximum potential for $\mathrm{CO}_{2}$ sequestration by "stimulated" weathering on the global scale? Naturwissenschaften 95, 1159-1164. doi:10.1007/s00114-008-0434-4

Hartmann, J., Jansen, N., Dürr, H.H., Kempe, S., Köhler, P., 2009. Global CO2-consumption by chemical weathering: What is the contribution of highly active weathering regions? Global and Planetary Change 69, 185-194. doi:10.1016/j.gloplacha.2009.07.007

Hartmann, J., West, A.J., Renforth, P., Köhler, P., De La Rocha, C.L., Wolf-Gladrow, D.A., Dürr, H.H., Scheffran, J., 2013. Enhanced chemical weathering as a geoengineering strategy to reduce atmospheric carbon dioxide, supply nutrients, and mitigate ocean acidification. Rev. Geophys. 51, 113-149. doi:10.1002/rog.20004

Harvey, L.D.D., 2008. Mitigating the atmospheric $\mathrm{CO}_{2}$ increase and ocean acidification by adding limestone powder to upwelling regions. J Geophys Res 113, C04028. doi:10.1029/2007jc004373

Hassenkam, T., Johnsson, A., Bechgaard, K., Stipp, S.L.S., 2011. Tracking single coccolith dissolution with picogram resolution and implications for $\mathrm{CO}_{2}$ sequestration and ocean acidification. Proc. Natl. Acad. Sci. U. S. A. 108, 8571-8576. doi:10.1073/pnas.1009447108

Hauck, J., Köhler, P., Wolf-Gladrow, D., Völker, C., 2016. Iron fertilisation and centuryscale effects of open ocean dissolution of olivine in a simulated $\mathrm{CO}_{2}$ removal experiment. Environ. Res. Lett. 11, 024007. doi: 10.1088/1748-9326/11/2/024007

Hauck, J., Völker, C., 2015. Rising atmospheric $\mathrm{CO}_{2}$ leads to large impact of biology on Southern Ocean CO2 uptake via changes of the Revelle factor. Geophys. Res. Lett. 42, 1459-1464. doi:10.1002/2015GL063070 
Henderson, G.M., Rickaby, R.E.M., Bouman, H., 2008. Decreasing atmosphere $\mathrm{CO}_{2}$ by increasing ocean alkalinity. https://www.earth.ox.ac.uk/ gideonh/reports/Cquestrate_report.pdf

Hermoso, M., 2015. Control of ambient $\mathrm{pH}$ on growth and stable isotopes in phytoplanktonic calcifying algae. Paleoceanography 30 (8) 1100 - 1112 doi:10.1002/2015PA002844

Hilbert, M., López, P., 2011. The World's Technological Capacity to Store, Communicate, and Compute Information. Science 332, 60-65. doi: 10.1126/science.1200970

Hoegh-Guldberg, O., Mumby, P.J., Hooten, A.J., Steneck, R.S., Greenfield, P., Gomez, E., Harvell, C.D., Sale, P.F., Edwards, A.J., Caldeira, K., Knowlton, N., Eakin, C.M., Iglesias-Prieto, R., Muthiga, N., Bradbury, R.H., Dubi, A., Hatziolos, M.E., 2007. Coral Reefs Under Rapid Climate Change and Ocean Acidification. Science 318, 1737-1742. doi:10.1126/science.1152509

Hönisch, B., Hemming, N.G., Archer, D., Siddall, M., McManus, J.F., 2009. Atmospheric Carbon Dioxide Concentration Across the Mid-Pleistocene Transition. Science 324, 1551-1554. doi:10.1126/science. 1171477

Honjo, S., Erez, J., 1978. Dissolution rates of calcium carbonate in the deep ocean; an in-situ experiment in the North Atlantic Ocean. Earth Planet. Sci. Lett. 40, 287-300. doi:10.1016/0012-821X(78)90099-7

Hoppe, C.J.M., Langer, G., Rost, B., 2011. Emiliania huxleyi shows identical responses to elevated pCO2 in TA and DIC manipulations. J. Exp. Mar. Biol. Ecol. 406, 54-62. doi:10.1016/j.jembe.2011.06.008

House, K.Z., House, C.H., Schrag, D.P., Aziz, M.J., 2007. Electrochemical Acceleration of Chemical Weathering as an Energetically Feasible Approach to Mitigating Anthropogenic Climate Change. Environ. Sci. Technol. 41, 8464-8470. doi:10.1021/es0701816

Hubert, A.-M., Reichwein, D., 2015. An Exploration of a Code of Conduct for Responsible Scientific Research involving Geoengineering. Introduction, Draft Articles and Commentaries. http://www.insis.ox.ac.uk/fileadmin/images/misc/An_Exploration_of_a_Code_of_Co nduct.pdf

Hutchins, D.A., Fu, F.-X., Zhang, Y., Warner, M.E., Feng, Y., Portune, K., Bernhardt, P.W., Mulholland, M.R., 2007. $\mathrm{CO}_{2}$ control of Trichodesmium $\mathrm{N}_{2}$ fixation, photosynthesis, growth rates, and elemental ratios: Implications for past, present, and future ocean biogeochemistry. Limnol. Oceanogr. 52, 1293-1304. doi:10.4319/lo.2007.52.4.1293

Iglesias-Rodriguez, M.D., Halloran, P.R., Rickaby, R.E.M., Hall, I.R., Colmenero-Hidalgo, E., Gittins, J.R., Green, D.R.H., Tyrrell, T., Gibbs, S.J., von Dassow, P., Rehm, E., Armbrust, E.V., Boessenkool, K.P., 2008. Phytoplankton Calcification in a High- $\mathrm{CO}_{2}$ World. Science 320, 336-340. doi: 10.1126/science.1154122

Ilyina, T., Wolf-Gladrow, D., Munhoven, G., Heinze, C., 2013. Assessing the potential of calcium-based artificial ocean alkalinization to mitigate rising atmospheric $\mathrm{CO} 2$ and ocean acidification. Geophys. Res. Lett. 40, 5909-5914. doi:10.1002/2013GL057981

IMCO (1975) Procedures and arrangements for the discharge of noxious liquid substances. Method for calculation of dilution capacity in the ship's wake. IMCO document MEPC III-7, May 27, 1975

IMO, 2008. Resolution LC-LP.1., 2008. On the Amendment to the London Protocol to Regulate the Placement of Matter for Ocean Fertilization and Other Marine Geoengineering Activities (Adopted on 18 October 2013), 10 pp. http://www. whoi.edu/fileserver.do?id=56339\&pt=10\&p=39373

IMO, 2003. London Convention 1972 and 1996 Protocol. IMO Publication, ISBN 92-8014155-4, 39. 
Inskeep, W.P., Bloom, P.R., 1985. An evaluation of rate-equations for calcite precipitation kinetics at $\mathrm{pCO}_{2}$ less than $0.01 \mathrm{~atm}$ and $\mathrm{pH}$ greater than 8. Geochim. Cosmochim. Acta 49, 2165-2180. doi:10.1016/0016-7037(85)90074-2

Joos, F., Plattner, G.-K., Stocker, T.F., Körtzinger, A., Wallace, D.W.R., 2003. Trends in marine dissolved oxygen: Implications for ocean circulation changes and the carbon budget. Eos Trans. Am. Geophys. Union 84, 197-201. doi:10.1029/2003EO210001

Keir, R.S., 1980. The dissolution kinetics of biogenic calcium carbonates in seawater. Geochim. Cosmochim. Acta 44, 241-252. doi:10.1016/0016-7037(80)90135-0

Keller, D.P., Feng, E.Y., Oschlies, A., 2014. Potential climate engineering effectiveness and side effects during a high carbon dioxide-emission scenario. Nat Commun 5. doi: $10.1038 /$ ncomms4304

Kheshgi, H.S., 1995. Sequestering atmospheric carbon dioxide by increasing ocean alkalinity. Energy 20, 915-922. doi:10.1016/0360-5442(95)00035-F

Klaas, C., Archer, D.E., 2002. Association of sinking organic matter with various types of mineral ballast in the deep sea: Implications for the rain ratio. Glob. Biogeochem. Cycles 16, 63-1. doi: 10.1029/2001GB001765

Köhler, P., Abrams, J.F., Völker, C., Hauck, J., Wolf-Gladrow, D.A., 2013. Geoengineering impact of open ocean dissolution of olivine on atmospheric $\mathrm{CO}_{2}$, surface ocean $\mathrm{pH}$ and marine biology. Environ. Res. Lett. 8, 014009. doi: 10.1088/17489326/8/1/014009

Köhler, P., Hartmann, J., Wolf-Gladrow, D.A., 2011. Reply to Schuiling et al.: Different processes at work. Proc. Natl. Acad. Sci. 108, E42. doi:10.1073/pnas.1019468108

Köhler, P., Hartmann, J., Wolf-Gladrow, D.A., 2010. Geoengineering potential of artificially enhanced silicate weathering of olivine. Proc. Natl. Acad. Sci. 107, 20228-20233. doi:10.1073/pnas.1000545107

Lackner, K.S., 2002. Carbonate chemistry for sequestering fossil carbon. Annu. Rev. Energy Environ. 27, 193-232. doi:10.1146/annurev.energy.27.122001.083433

Lampitt, R.., Achterberg, E.., Anderson, T.., Hughes, J.., Iglesias-Rodriguez, M.., KellyGerreyn, B.., Lucas, M., Popova, E.., Sanders, R., Shepherd, J.., Smythe-Wright, D., Yool, A., 2008. Ocean fertilization: a potential means of geoengineering? Philos. Trans. R. Soc. Lond. Math. Phys. Eng. Sci. 366, 3919-3945. doi:10.1098/rsta.2008.0139

Langdon, C., Atkinson, M.J., 2005. Effect of elevated $\mathrm{pCO}_{2}$ on photosynthesis and calcification of corals and interactions with seasonal change in temperature/irradiance and nutrient enrichment. J. Geophys. Res. Oceans 110, C9. doi:10.1029/2004JC002576

Langdon, C., Takahashi, T., Sweeney, C., Chipman, D., Goddard, J., Marubini, F., Aceves, H., Barnett, H., Atkinson, M.J., 2000. Effect of calcium carbonate saturation state on the calcification rate of an experimental coral reef. Glob. Biogeochem. Cycles 14, 639-654. doi:10.1029/1999GB001195

Langer, G., Geisen, M., Baumann, K.-H., Kläs, J., Riebesell, U., Thoms, S., Young, J.R., 2006. Species-specific responses of calcifying algae to changing seawater carbonate chemistry. Geochem. Geophys. Geosystems 7, Q09006. doi:10.1029/2005GC001227

Langer, W.H., Juan, C. A. S., Rau, G. H., Caldeira, K., 2009. Accelerated weathering of limestone for $\mathrm{CO}_{2}$ mitigation opportunities for the stone and cement industries. Min. Eng. 61, (2) 310-315.

Leclercq, N. colas, Gattuso, J., Jaubert, J., 2000. $\mathrm{CO}_{2}$ partial pressure controls the calcification rate of a coral community. Glob. Change Biol. 6, 329-334. doi: 10.1046/j.1365-2486.2000.00315.x 
Lee, K., Tong, L.T., Millero, F.J., Sabine, C.L., Dickson, A.G., Goyet, C., Park, G.-H., Wanninkhof, R., Feely, R.A., Key, R.M., 2006. Global relationships of total alkalinity with salinity and temperature in surface waters of the world's oceans. Geophys. Res. Lett. 33, L19605, doi:10.1029/2006GL027207

Levin, L.A., Ekau, W., Gooday, A.J., Jorissen, F., Middelburg, J.J., Naqvi, S.W.A., Neira, C., Rabalais, N.N., Zhang, J., 2009. Effects of natural and human-induced hypoxia on coastal benthos. Biogeosciences 6, 2063-2098. doi:10.5194/bg-6-2063-2009

Lewis, E., Wallace, D., Allison, L.J., 1998. Program developed for $\mathrm{CO}_{2}$ system calculations. Carbon Dioxide Information Analysis Center, managed by Lockheed Martin Energy Research Corporation for the US Department of Energy Tennessee. http://cdiac.ornl.gov/oceans/co2rprt.html

Lewis, R.E., 1985. The dilution of waste in the wake of a ship. Water Res. 19, 941-945. doi:10.1016/0043-1354(85)90360-4

Lin, Y.-P., Singer, P.C., 2009. Effect of $\mathrm{Mg}^{2+}$ on the kinetics of calcite crystal growth. $J$. Cryst. Growth 312, 136-140. doi:10.1016/j.jcrysgro.2009.09.041

Lior, N., 2012. Advances in Water Desalination, Advances in Water Desalination. Wiley.

Liu, Z., Dreybrodt, W., Liu, H., 2011. Atmospheric $\mathrm{CO}_{2}$ sink: Silicate weathering or carbonate weathering? Ninth Int. Symp. Geochem. Earths Surf. GES-9 26, Supplement, S292-S294. doi:10.1016/j.apgeochem.2011.03.085

Locke, A., Doe, K.G., Fairchild, W.L., Jackman, P.M., Reese, E.J., 2009. Preliminary evaluation of effects of invasive tunicate management with acetic acid and calcium hydroxide on non-target marine organisms in Prince Edward Island, Canada. Aquat. Invasions 4, 221-236. doi: 10.3391/ai.2009.4.1.23

Lopez, O., Zuddas, P., Faivre, D., 2009. The influence of temperature and seawater composition on calcite crystal growth mechanisms and kinetics: Implications for $\mathrm{Mg}$ incorporation in calcite lattice. Geochim. Cosmochim. Acta 73, 337-347. doi:10.1016/j.gca.2008.10.022

Lord, N. S., A. Ridgwell, M. C. Thorne, and D. J. Lunt (2016), An impulse response function for the "long tail" of excess atmospheric $\mathrm{CO}_{2}$ in an Earth system model, Global Biogeochem. Cycles, 30, 2-17, doi:10.1002/2014GB005074.

Lu, Z., Rickaby, R.E.M., Kennedy, H., Kennedy, P., Pancost, R.D., Shaw, S., Lennie, A., Wellner, J., Anderson, J.B., 2012. An ikaite record of late Holocene climate at the Antarctic Peninsula. Earth Planet. Sci. Lett. 325-326, 108-115. doi:10.1016/j.epsl.2012.01.036

Mackenzie, F.T., Andersson, A.J., 2013. The marine carbon system and ocean acidification during Phanerozoic time. Geochem. Perspect. 2, 1-3. doi: 10.7185/geochempersp.2.1

Madeddu, S., Priestnall, M., Kinoshita, H., Godoy, E., 2014. Alkaline digestion of dunite for $\mathrm{Mg}(\mathrm{OH})_{2}$ production: An investigation for indirect $\mathrm{CO}_{2}$ sequestration. Miner. Eng. 59, 31-38. doi:10.1016/j.mineng.2013.10.015

Maier, C., Watremez, P., Taviani, M., Weinbauer, M.G., Gattuso, J.P., 2011. Calcification rates and the effect of ocean acidification on Mediterranean cold-water corals. Proc. R. Soc. Lond. B Biol. Sci. doi:10.1098/rspb.2011.1763

Manning, D.A.C., 2008. Biological enhancement of soil carbonate precipitation: passive removal of atmospheric $\mathrm{CO}_{2}$. Mineral. Mag. 72, 639-649. doi: 10.1180/minmag.2008.072.2.639

Manning, D.A.C., Renforth, P., 2013. Passive Sequestration of Atmospheric $\mathrm{CO}_{2}$ through Coupled Plant-Mineral Reactions in Urban soils. Environ. Sci. Technol. 47, 135-141. doi:10.1021/es301250j

Manning, D.A.C., Renforth, P., Lopez-Capel, E., Robertson, S., Ghazireh, N., 2013. Carbonate precipitation in artificial soils produced from basaltic quarry fines and 
composts: An opportunity for passive carbon sequestration. Int. J. Greenh. Gas Control 17, 309-317. doi: 10.1016/j.ijggc.2013.05.012

Marshall, B.J., Thunell, R.C., Henehan, M.J., Astor, Y., Wejnert, K.E., 2013. Planktonic foraminiferal area density as a proxy for carbonate ion concentration: A calibration study using the Cariaco Basin ocean time series. Paleoceanography 28, 363-376. doi:10.1002/palo. 20034

Marsh, M.., 2003. Regulation of $\mathrm{CaCO}_{3}$ formation in coccolithophores. Comp. Biochem. Physiol. B Biochem. Mol. Biol. 136, 743-754. doi:10.1016/S1096-4959(03)00180-5

McLaren, D., 2012. A comparative global assessment of potential negative emissions technologies. Process Safety and Environmental Protection 90, 489-500. doi:10.1016/j.psep.2012.10.005

McCulloch, M., Falter, J., Trotter, J., Montagna, P., 2012. Coral resilience to ocean acidification and global warming through $\mathrm{pH}$ up-regulation. Nat. Clim Change 2, 623-627. doi:10.1038/nclimate1473

McGlade, C., Ekins, P., 2015. The geographical distribution of fossil fuels unused when limiting global warming to $2^{\circ} \mathrm{C}$. Nature 517, 187-190. doi:10.1038/nature14016

McInerney, F.A., Wing, S.L., 2011. The Paleocene-Eocene Thermal Maximum: a perturbation of carbon cycle, climate, and biosphere with implications for the future. Annu. Rev. Earth Planet. Sci. 39, 489-516.

Mendoza, H., 2012. Valley of Mexico's Sustainability Program: Implementing the Largest Agricultural Reuse Water Reclamation Project in History. Proc. Water Environ. Fed. 2012, 3470-3478. doi: 10.2175/193864712811727076

Metz, B., Davidson, O., de Coninck, H., Loos, M., Meyer, L., 2005. IPCC Special Report on Carbon Dioxide Capture and Storage. Cambridge University Press.

Meysman, F.J.R., Monserrat, F. 2017. Negative $\mathrm{CO}_{2}$ emissions via enhanced silicate weathering in coastal environments. Biol. Lett. 13. 20160905. doi: 10.1098/rsbl.2016.0905

Miyashiro, A., 1975. Classification, Characteristics, and Origin of Ophiolites. J. Geol. 83, 249-281. doi:10.2307/30060218

Moosdorf, N., Renforth, P., Hartmann, J., 2014. Carbon Dioxide Efficiency of Terrestrial Enhanced Weathering. Environ. Sci. Technol. 48, 4809-4816. doi:10.1021/es4052022

Montserrat, F., Renforth, P., Hartmann, J., Leermakers, M., Knops, P., Meysman, F.J.R. Olivine Dissolution in Seawater: Implications for $\mathrm{CO}_{2}$ Sequestration through Enhanced Weathering in Coastal Environments. Environ. Sci. Technol. 51 (7) 39603972. doi: 10.1021/acs.est.6b05942

Morse, J.W., Arvidson, R.S., Lüttge, A., 2007. Calcium Carbonate Formation and Dissolution. Chem. Rev. 107, 342-381. doi:10.1021/cr050358j

Morse, J.W., Gledhill, D.K., Millero, F.J., 2003. Caco3 precipitation kinetics in waters from the great Bahama bank:: Implications for the relationship between bank hydrochemistry and whitings. Geochim. Cosmochim. Acta 67, 2819-2826. doi:10.1016/S0016-7037(03)00103-0

Morse, J.W., He, S., 1993. Influences of T, S and $\mathrm{PCO}_{2}$ on the pseudo-homogeneous precipitation of $\mathrm{CaCO}_{3}$ from seawater: implications for whiting formation. Mar. Chem. 41, 291-297.

Morse, J.W., Wang, Q., Tsio, M.Y., 1997. Influences of temperature and Mg:Ca ratio on $\mathrm{CaCO}_{3}$ precipitates from seawater. Geology 25, 85-87.

Mucci, A., 1986. Growth kinetics and composition of magnesian calcite overgrowths precipitated from seawater: Quantitative influence of orthophosphate ions. Geochim. Cosmochim. Acta 50, 2255-2265. doi:10.1016/0016-7037(86)90080-3 
Mucci, A., 1983. The solubility of calcite and aragonite in seawater at various salinities, temperatures and one atmosphere total pressure. Am. J. Sci. 283. 780-799. doi: 10.2475/ajs.283.7.780

Mucci, A., Canuel, R., Zhong, S., 1989. The solubility of calcite and aragonite in sulfate-free seawater and the seeded growth kinetics and composition of the precipitates at $25^{\circ} \mathrm{C}$. Chem. Geol. 74, 309-320. doi:10.1016/0009-2541(89)90040-5

Mucci, A., Morse, J.W., 1983. The incorporation of $\mathrm{Mg}^{2+}$ and $\mathrm{Sr}^{2+}$ into calcite overgrowths: influences of growth rate and solution composition. Geochim. Cosmochim. Acta 47, 217-233. doi:10.1016/0016-7037(83)90135-7

Müller, W.E., 2011. Molecular Biomineralization: Aquatic Organisms Forming Extraordinary Materials. Springer Science \& Business Media.

NAS, 2015. Climate Intervention: Carbon Dioxide Removal and Reliable Sequestration.

Nduagu, E., Björklöf, T., Fagerlund, J., Wärnå, J., Geerlings, H., Zevenhoven, R., 2012. Production of magnesium hydroxide from magnesium silicate for the purpose of $\mathrm{CO}_{2}$ mineralisation - Part 1: Application to Finnish serpentinite. Miner. Eng. 30, 75-86. doi:10.1016/j.mineng.2011.12.004

Nilsson, S., Schopfhauser, W., 1995. The carbon-sequestration potential of a global afforestation program. Clim Change 30, 267-293. doi:10.1007/BF01091928

Opdyke, B.N., Walker, J.C., 1992. Return of the coral reef hypothesis: Basin to shelf partitioning of $\mathrm{CaCO}_{3}$ and its effect on atmospheric $\mathrm{CO}_{2}$. Geology 20, 733-736.

Owen, R., Stilgoe, J., Macnaghten, P., Gorman, M., Fisher, E., Guston, D., 2013. A Framework for Responsible Innovation, in: Responsible Innovation. John Wiley \& Sons, Ltd, pp. 27-50.

Pacala, S., Socolow, R., 2004. Stabilization wedges: solving the climate problem for the next 50 years with current technologies. Science 305, 968-972.

doi:10.1126/science. 1100103

PAGES (2016), Interglacials of the last 800,000 years, Rev. Geophys., 54, 162-219, doi:10.1002/2015RG000482.

Parkhurst, D.L., Appelo, C., 1999. User's guide to PHREEQC (Version 2): A computer program for speciation, batch-reaction, one-dimensional transport, and inverse geochemical calculations.

ftp://brrftp.cr.usgs.gov/pub/charlton/phreeqc/Phreeqc_2_1999_manual.pdf

Parkhurst, D.L., Thorstenson, D.C., and Plummer, L.N., 1980. PHREEQE--A computer program for geochemical calculations: U.S. Geological Survey Water-Resources Investigations Report 80-96, 195 p. (Revised and reprinted August, 1990.)

Paquay, F.S., Zeebe, R.E., 2013. Assessing possible consequences of ocean liming on ocean $\mathrm{pH}$, atmospheric $\mathrm{CO}_{2}$ concentration and associated costs. Int. J. Greenh. Gas Control 17, 183-188. doi:10.1016/j.ijggc.2013.05.005

Pilson, M.E.Q., 1998. An Introduction to the Chemistry of the Sea. Prentice Hall.

Piola, R.F., Dunmore, R.A., Forrest, B.M., 2009. Assessing the efficacy of spray-delivered "eco-friendly" chemicals for the control and eradication of marine fouling pests. Biofouling 26, 187-203. doi:10.1080/08927010903428029

Pokrovsky, O.S., 1998. Precipitation of calcium and magnesium carbonates from homogeneous supersaturated solutions. J. Cryst. Growth 186, 233-239. doi:10.1016/S0022-0248(97)00462-4

Pytkowicz, R.M., 1965. Rates of Inorganic Calcium Carbonate Nucleation. J. Geol. 73, 196199. doi:10.2307/30066391

Ramos, J.B. e, Biswas, H., Schulz, K.G., LaRoche, J., Riebesell, U., 2007. Effect of rising atmospheric carbon dioxide on the marine nitrogen fixer Trichodesmium. Glob. Biogeochem. Cycles 21 GB2028. doi:10.1029/2006GB002898 
Rau, G.H., 2011. $\mathrm{CO}_{2}$ Mitigation via Capture and Chemical Conversion in Seawater. Environ. Sci. Technol. 45, 1088-1092. doi:10.1021/es102671x

Rau, G.H., 2008. Electrochemical Splitting of Calcium Carbonate to Increase Solution Alkalinity: Implications for Mitigation of Carbon Dioxide and Ocean Acidity. Environ. Sci. Technol. 42, 8935-8940. doi:10.1021/es800366q

Rau, G.H., Caldeira, K., 1999. Enhanced carbonate dissolution:: a means of sequestering waste CO2 as ocean bicarbonate. Energy Convers. Manag. 40, 1803-1813. doi:10.1016/S0196-8904(99)00071-0

Rau, G.H., Carroll, S.A., Bourcier, W.L., Singleton, M.J., Smith, M.M., Aines, R.D., 2013. Direct electrolytic dissolution of silicate minerals for air $\mathrm{CO}_{2}$ mitigation and carbonnegative $\mathrm{H}_{2}$ production. Proc. Natl. Acad. Sci. 110, 10095-10100.

Rau, G.H., Knauss, K.G., Langer, W.H., Caldeira, K., 2007. Reducing energy-related $\mathrm{CO}_{2}$ emissions using accelerated weathering of limestone. Energy 32, 1471-1477.

Rau, G.H., McLeod, E.L., Hoegh-Guldberg, O., 2012. The need for new ocean conservation strategies in a high-carbon dioxide world. Nat. Clim Change 2, 720-724. doi: 10.1038/nclimate1555

Rayner, S., Heyward, C., Kruger, T., Pidgeon, N., Redgwell, C., Savulescu, J., 2013. The Oxford Principles. Clim. Change 121, 499-512. doi:10.1007/s10584-012-0675-2

Renforth, P., 2012. The potential of enhanced weathering in the UK. Int. J. Greenh. Gas Control 10, 229-243.

Renforth, P., Jenkins, B.G., Kruger, T., 2013. Engineering challenges of ocean liming. Energy 60, 442-452.

Renforth, P., Kruger, T., 2013. Coupling Mineral Carbonation and Ocean Liming. Energy Fuels 27, 4199-4207. doi:10.1021/ef302030w

Renforth, P., Manning, D.A.C., Lopez-Capel, E., 2009. Carbonate precipitation in artificial soils as a sink for atmospheric carbon dioxide. Appl. Geochem. 24, 1757-1764.

Renforth, P., Washbourne, C.L., Taylder, J., Manning, D.A.C., 2011. Silicate Production and Availability for Mineral Carbonation. Environ. Sci. Technol. 45, 2035-2041. doi:10.1021/es103241w

Revelle, R., Suess, H.E., 1957. Carbon Dioxide Exchange Between Atmosphere and Ocean and the Question of an Increase of Atmospheric $\mathrm{CO}_{2}$ during the Past Decades. Tellus A 9, 18-27.

Rickaby, R.E.M., Henderiks, J., Young, J.N., 2010. Perturbing phytoplankton: response and isotopic fractionation with changing carbonate chemistry in two coccolithophore species. Clim. Past 6, 771-785. doi:10.5194/cp-6-771-2010

Ricke, K.L., Orr, J.C., Schneider, K., Caldeira, K., 2013. Risks to coral reefs from ocean carbonate chemistry changes in recent earth system model projections. Environ. Res. Lett. 8, 034003. doi: 10.1088/1748-9326/8/3/034003

Ridgwell, A., 2007. Interpreting transient carbonate compensation depth changes by marine sediment core modeling. Paleoceanography 22. (4) doi: 10.1029/2006PA001372

Ridgwell, A. and Zeebe, R. 2005. The role of the global carbonate cycle in the regulation and evolution of the Earth system. Earth Planet. Sci. Lett. 234, 299-315 doi: 10.1016/j.eps1.2005.03.006

Riebesell, U., Zondervan, I., Rost, B., Tortell, P.D., Zeebe, R.E., Morel, F.M.M., 2000. Reduced calcification of marine plankton in response to increased atmospheric $\mathrm{CO}_{2}$. Nature 407, 364-367. doi:10.1038/35030078

Ries, J.B., Cohen, A.L., McCorkle, D.C., 2009. Marine calcifiers exhibit mixed responses to $\mathrm{CO}_{2}$-induced ocean acidification. Geology 37, 1131-1134. doi: 10.1130/G30210A.1 
Robie, R.A., Hemingway, B.S., 1979. Thermodynamic Properties of Minerals and Related Substances at 298.15 K and 1 Bar (105 Pascals) Pressure and at Higher Temperatures., United States Geological Survey Bulletin 2131. Washington.

Rogelj, J., den Elzen, M., Höhne, N., Fransen, T., Fekete, H., Winkler, H., Schaeffer, R., Sha, F., Riahi, K., Meinshausen, M., 2016. Paris Agreement climate proposals need a boost to keep warming well below $2{ }^{\circ} \mathrm{C}$. Nature 534, 631-639.

Rokitta, S.D., John, U., Rost, B., 2012. Ocean Acidification Affects Redox-Balance and IonHomeostasis in the Life-Cycle Stages of Emiliania huxleyi. PLoS ONE 7, e52212. doi:10.1371/journal.pone.0052212

Rost B, Zondervan I, Wolf-Gladrow D, 2008. Sensitivity of phytoplankton to future changes in ocean carbonate chemistry: current knowledge, contradictions and research directions. Mar. Ecol. Prog. Ser. 373, 227-237. doi 10.3354/meps07776

Roth, R., Divall, C., 2015. From Rail to Road and Back Again?: A Century of Transport Competition and Interdependency, Modern Economic and Social History. Ashgate Publishing Limited.

Roy, R.N., Roy, L.N., Vogel, K.M., Porter-Moore, C., Pearson, T., Good, C.E., Millero, F.J., Campbell, D.M., 1993. The dissociation constants of carbonic acid in seawater at salinities 5 to 45 and temperatures 0 to $45^{\circ}$ C. Mar. Phys. Chem. - Mem. Contrib. 44, 249-267. doi:10.1016/0304-4203(93)90207-5

Sabine, C.L., Feely, R.A., Gruber, N., Key, R.M., Lee, K., Bullister, J.L., Wanninkhof, R., Wong, C.S., Wallace, D.W.R., Tilbrook, B., Millero, F.J., Peng, T.-H., Kozyr, A., Ono, T., Rios, A.F., 2004. The Oceanic Sink for Anthropogenic $\mathrm{CO}_{2}$. Science 305, 367-371. doi: 10.1126/science.1097403

Sabine, C.L., Tanhua, T. 2010. Estimation of Anthropogenic $\mathrm{CO}_{2}$ Inventories in the Ocean. An. Rev. Mar. Sci. 2 175-198. doi: 10.1146/annurev-marine-120308-080947

Saha, N., Dutta, S., Bhattacharjee, A., 2002. Role of amino acid metabolism in an airbreathing catfish, Clarias batrachus in response to exposure to a high concentration of exogenous ammonia. Comp. Biochem. Physiol. B Biochem. Mol. Biol. 133, 235-250. doi:10.1016/S1096-4959(02)00145-8

Sanna, A., Uibu, M., Caramanna, G., Kuusik, R., Maroto-Valer, M.M., 2014. A review of mineral carbonation technologies to sequester CO2. Chem. Soc. Rev. 43, 8049-8080. doi:10.1039/C4CS00035H

Schneider, K., Silverman, J., Woolsey, E., Eriksson, H., Byrne, M., Caldeira, K., 2011. Potential influence of sea cucumbers on coral reef $\mathrm{CaCO}_{3}$ budget: A case study at One Tree Reef. J. Geophys. Res. Biogeosciences 116, G04032. doi:10.1029/2011JG001755

Schott, J., Berner, R., 1985. Dissolution Mechanisms of Pyroxenes and Olivines During Weathering, in: Drever, J. (Ed.), The Chemistry of Weathering, Nato ASI Series. Springer Netherlands, pp. 35-53.

Schuiling, R.D., de Boer, P.L., 2010. Coastal spreading of olivine to control atmospheric $\mathrm{CO} 2$ concentrations: A critical analysis of viability. Comment: Nature and laboratory models are different. Int. J. Greenh. Gas Control 4, 855-856. doi:http://dx.doi.org/10.1016/j.ijggc.2010.04.012

Schuiling, R.D., Krijgsman, P., 2006. Enhanced weathering: An effective and cheap tool to sequester $\mathrm{CO}_{2}$. Clim. Change 74, 349-354. doi:10.1007/s10584-005-3485-y

Scott, D.M., Lucas, M.C., Wilson, R.W., 2005. The effect of high pH on ion balance, nitrogen excretion and behaviour in freshwater fish from an eutrophic lake: A laboratory and field study. Aquat. Toxicol. 73, 31-43.

doi:10.1016/j.aquatox.2004.12.013 
Shackley, S., Green, K., 2007. A conceptual framework for exploring transitions to decarbonised energy systems in the United Kingdom. Energy 32, 221-236. doi:10.1016/j.energy.2006.04.010

Sigman, D.M., Boyle, E.A., 2000. Glacial/interglacial variations in atmospheric carbon dioxide. Nature 407, 859-869. doi:10.1038/35038000

Sigman, D.M., Hain, M.P., Haug, G.H., 2010. The polar ocean and glacial cycles in atmospheric CO2 concentration. Nature 466, 47-55. doi:10.1038/nature09149

Smetak, K.M., Johnson-Maynard, J.L., Lloyd, J.E., 2007. Earthworm population density and diversity in different-aged urban systems. Appl. Soil Ecol. 37, 161-168. doi:10.1016/j.apsoil.2007.06.004

Smith, S.V., Kinsey, D.W., 1976. Calcium Carbonate Production, Coral Reef Growth, and Sea Level Change. Science 194, 937-939. DOI: 10.1126/science.194.4268.937

Stephens, J., Keith, D., 2008. Assessing geochemical carbon management. Clim. Change 90, 217-242. doi:10.1007/s10584-008-9440-y

Stramma, L., Johnson, G.C., Sprintall, J., Mohrholz, V., 2008. Expanding Oxygen-Minimum Zones in the Tropical Oceans. Science 320, 655-658. doi: 10.1126/science.1153847

Suchet, P.A., Probst, J.-L., 1995. A global model for present-day atmospheric/soil $\mathrm{CO}_{2}$ consumption by chemical erosion of continental rocks $\left(\mathrm{GEM}-\mathrm{CO}_{2}\right)$. Tellus $\mathrm{B} 47,273-$ 280.

Switzer, S., Therriault, T., Dunham, A., Pearce, C., 2011. Assessing potential control options for the invasive tunicate Didemnum vexillum in shellfish aquaculture. Aquaculture 318, 145-153. doi:10.1016/j.aquaculture.2011.04.044

Tang, Y., Zhang, F., Cao, Z., Jing, W., Chen, Y., 2012. Crystallization of $\mathrm{CaCO}_{3}$ in the presence of sulfate and additives: Experimental and molecular dynamics simulation studies. J. Colloid Interface Sci. 377, 430-437. doi:10.1016/j.jcis.2012.02.069

Taylor, L.L., Quirk, J., Thorley, R.M.S., Kharecha, P.A., Hansen, J., Ridgwell, A., Lomas, M.R., Banwart, S.A., Beerling, D.J., 2016. Enhanced weathering strategies for stabilizing climate and averting ocean acidification. Nat. Clim Change 6, 402-406. doi:10.1038/nclimate2882

ten Berge, H.F.M., van der Meer, H.G., Steenhuizen, J.W., Goedhart, P.W., Knops, P., Verhagen, J., 2012. Olivine Weathering in Soil, and Its Effects on Growth and Nutrient Uptake in Ryegrass (Lolium perenne L.): A Pot Experiment. PLoS ONE 7, e42098. doi: 10.1371/journal.pone.0042098

The Royal Society, 2009. Geoengineering the climate: Science governance and uncertainty.

Tréguer, P., Nelson, D.M., Van Bennekom, A.J., DeMaster, D.J., Leynaert, A., Quéguiner, B., 1995. The Silica Balance in the World Ocean: A Reestimate. Science 268, 375. doi:10.1126/science.268.5209.375

Tullock, J.H., Earle-Bridges, M., 2002. Water Chemistry for the Marine Aquarium: Everything about Seawater, Cycles, Conditions, Components, and Analysis: Filled with Full-color Photographs. Barron's Educational Series.

UN, 1982. United Nations Convention on the Law of the Sea of 10 December 1982.

UNCTAD, 2012. Review of Maritime Transport. United Nations Conference on Trade and Development. ISBN: 978-92-1-112860-4.

UNFCCC. Adoption of the Paris Agreement. Report No. FCCC/CP/2015/L.9/Rev.1, http://unfccc.int/resource/docs/2015/cop21/eng/109r01.pdf (UNFCCC, 2015)

U.S. Environmental Protection Agency, 1998, MINTEQA2/PRODEFA2, A geochemical assessment model for environmental systems--User manual supplement for version 4.0: Athens, Georgia, National Exposure Research Laboratory, Ecosystems Research Division, 76 p. Revised September 1999. 
USGS, 2014. USGS Minerals Yearbook. U.S. Department of the Interior and U.S. Geological Survey.

van Vuuren, D.P., Stehfest, E., den Elzen, M.G.J., Kram, T., van Vliet, J., Deetman, S., Isaac, M., Klein Goldewijk, K., Hof, A., Mendoza Beltran, A., Oostenrijk, R., van Ruijven, B., 2011. RCP2.6: exploring the possibility to keep global mean temperature increase below $2^{\circ}$ C. Clim. Change 109, 95. doi:10.1007/s10584-011-0152-3

Vichi, M., Navarra, A., Fogli, P.G., 2013. Adjustment of the natural ocean carbon cycle to negative emission rates. Climatic Change 118, 105-118. doi:10.1007/s10584-0120677-0

Wallace, D., Law, C., Boyd, P., Collos, Y., Croot, P., Denman, K., Lam, P., Riebesell, U., Takeda, S., Williamson, P., 2010. Ocean fertilization: a scientific summary for policy makers. IOC/UNESCO Paris (IOC/BRO/2010/2) http://unesdoc.unesco.org/images/0019/001906/190674e.pdf

Walter, L.M., Hanor, J.S., 1979. Effect of orthophosphate on the dissolution kinetics of biogenic magnesian calcites. Geochim. Cosmochim. Acta 43, 1377-1385. doi:10.1016/0016-7037(79)90128-5

Walter, L.M., Morse, J.W., 1985. The dissolution kinetics of shallow marine carbonates in seawater: A laboratory study. Geochim. Cosmochim. Acta 49, 1503-1513. doi:10.1016/0016-7037(85)90255-8

Washbourne, C.-L., Lopez-Capel, E., Renforth, P., Ascough, P.L., Manning, D.A.C., 2015. Rapid Removal of Atmospheric $\mathrm{CO}_{2}$ by Urban Soils. Environ. Sci. Technol. 49, 5434-5440. doi:10.1021/es505476d

Washbourne, C.-L., Renforth, P., Manning, D.A.C., 2012. Investigating carbonate formation in urban soils as a method for capture and storage of atmospheric carbon. Sci. Total Environ. 431, 166-175. doi:10.1016/j.scitotenv.2012.05.037

West, A.J., Galy, A., Bickle, M., 2005. Tectonic and climatic controls on silicate weathering. Earth Planet. Sci. Lett. 235, 211-228.

White, A.F., Brantley, S.L., 1995. Chemical weathering rates of silicate minerals, Reviews in mineralogy. Mineralogical Society of America. vol. 31 no. 1 1-22. ISSN: 1529-6466

Williamson, P., Turley, C., 2012. Ocean acidification in a geoengineering context. Philos. Trans. R. Soc. Lond. Math. Phys. Eng. Sci. 370, 4317-4342. doi:10.1098/rsta.2012.0167

Williamson, P., Wallace, D.W.R., Law, C.S., Boyd, P.W., Collos, Y., Croot, P., Denman, K., Riebesell, U., Takeda, S., Vivian, C., 2012. Ocean fertilization for geoengineering: A review of effectiveness, environmental impacts and emerging governance. Spec. Issue Negat. Emiss. Technol. 90, 475-488. doi:10.1016/j.psep.2012.10.007

Wolf-Gladrow, D.A., Zeebe, R.E., Klaas, C., Körtzinger, A., Dickson, A.G., 2007. Total alkalinity: The explicit conservative expression and its application to biogeochemical processes. Mar. Chem. 106, 287-300.

Wood, C.M., Milligan, C.L., Walsh, P.J., 1999. Renal responses of trout to chronic respiratory and metabolic acidoses and metabolic alkalosis. Am. J. Physiol. - Regul. Integr. Comp. Physiol. 277, R482-R492.

Zachos, J.C., Röhl, U., Schellenberg, S.A., Sluijs, A., Hodell, D.A., Kelly, D.C., Thomas, E., Nicolo, M., Raffi, I., Lourens, L.J., 2005. Rapid acidification of the ocean during the Paleocene-Eocene thermal maximum. Science 308, 1611-1615. doi:

10.1126/science. 1109004

Zeebe, R.E., 2012. History of Seawater Carbonate Chemistry, Atmospheric $\mathrm{CO}_{2}$, and Ocean Acidification. Annu. Rev. Earth Planet. Sci. 40, 141-165. doi:10.1146/annurev-earth042711-105521 
Zeebe, R.E., Marchitto, T.M., 2010. Glacial cycles: Atmosphere and ocean chemistry. Nat. Geosci 3, 386-387. doi:10.1038/ngeo882

Zeebe, R.E., Wolf-Gladrow, D., 2001. $\mathrm{CO}_{2}$ in seawater: Equilibrium, kinetics, isotopes, Elsevier Oceanography Series. Elsevier Science B.V.

Zhong, S., Mucci, A., 1995. Partitioning of rare earth elements (REEs) between calcite and seawater solutions at $25^{\circ} \mathrm{C}$ and $1 \mathrm{~atm}$, and high dissolved REE concentrations. Geochim. Cosmochim. Acta 59, 443-453. doi:10.1016/0016-7037(94)00381-U

Zhong, S., Mucci, A., 1989. Calcite and aragonite precipitation from seawater solutions of various salinities: Precipitation rates and overgrowth compositions. Kinet. Geochem. 78, 283-299. doi:10.1016/0009-2541(89)90064-8 